Portland State University

PDXScholar

$1-1-1981$

\title{
An observational study of the workday of the urban high school assistant principal
}

Penny S. McDonald

Portland State University

Follow this and additional works at: https://pdxscholar.library.pdx.edu/open_access_etds Let us know how access to this document benefits you.

\section{Recommended Citation}

McDonald, Penny S., "An observational study of the workday of the urban high school assistant principal" (1981). Dissertations and Theses. Paper 593.

https://doi.org/10.15760/etd.593

This Dissertation is brought to you for free and open access. It has been accepted for inclusion in Dissertations and Theses by an authorized administrator of PDXScholar. Please contact us if we can make this document more accessible: pdxscholar@pdx.edu. 
AN OBSERVATIONAL STUDY OF THE WORKDAY OF THE

URBAN HIGH SCHOOL ASSISTANT PRINCIPAL

by

PENNY S. MC DONALD

A dissertation submitted in partial fulfillment of the requirements for the degree of

DOCTOR OF EDUCATION

in

PUBLIC SCHOOL ADMINISTRATION AND SUPERVISION

Portland State University

University of Oregon

1981 
TO THE OFFICE OF GRADUATE STUDIES AND RESEARCH:

The members of the committee approve the dissertation of Penny S. McDonald, presented Mav 1/ 1081

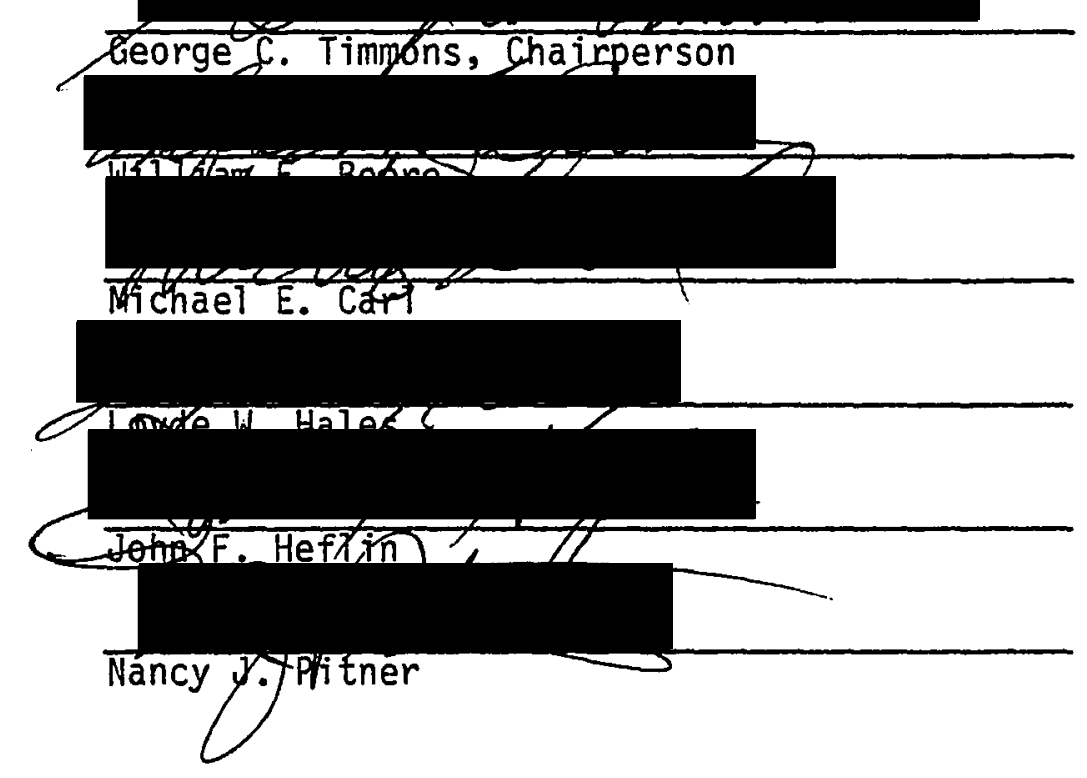

APPROVED:

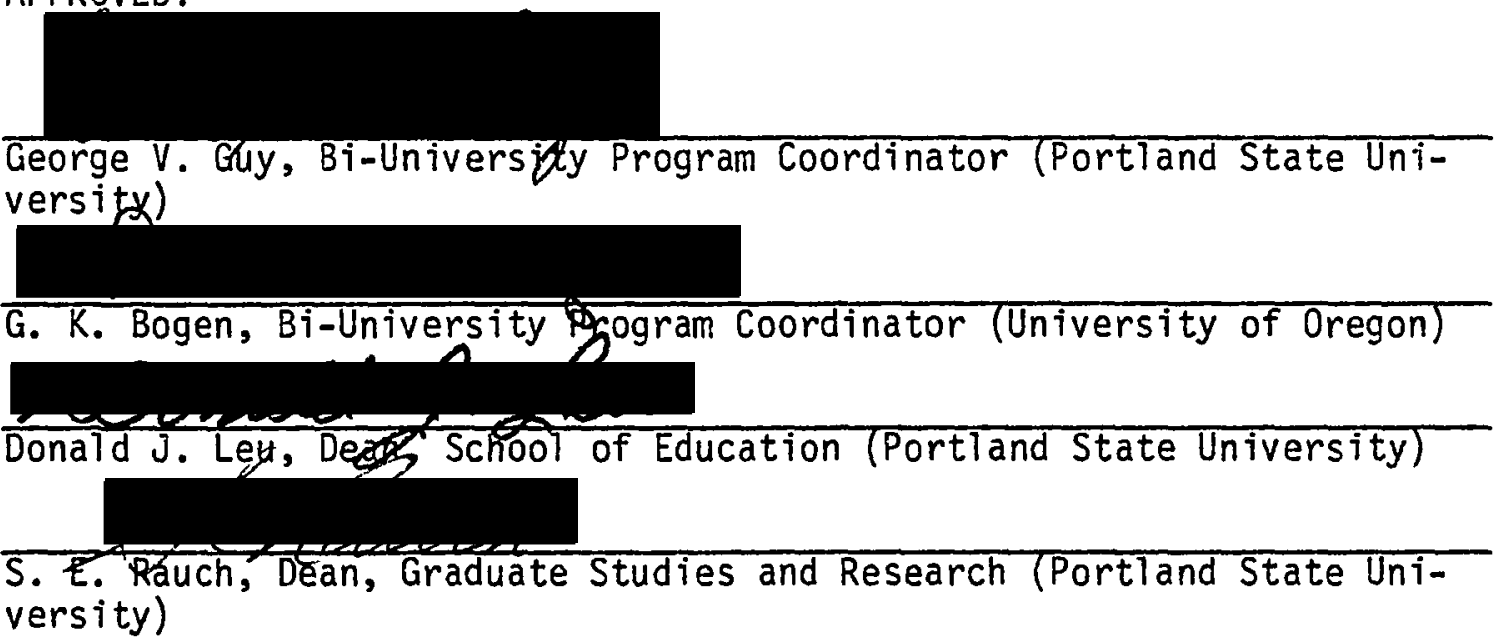


AN ABSTRACT OF THE DISSERTATION OF Penny S. MCDonald for the Doctor of Education presented May 12, 1981.

Title: An Observational Study of the Workday of the Urban High School Assistant Principalo?

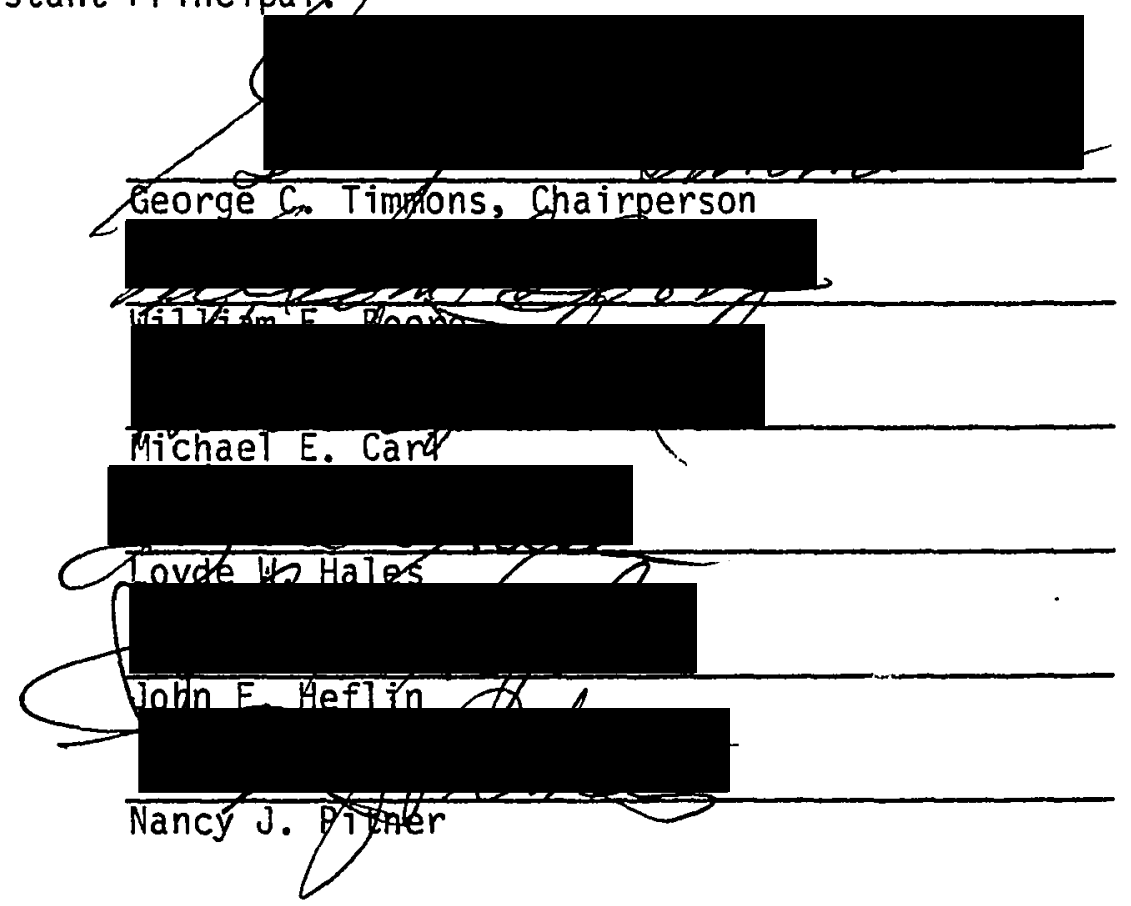

The central problem of the study was to determine the nature of the workday of the urban high school assistant principal. Specific questions guiding the investigation were as follows:

1. What are the workday activities of an assistant principal?

2. How long is this day?

3. How might the pace of the workday be described? 
4. With whom does an assistant principal interact? How? Why?

5. To what extent is daily work proactive? Reactive?

6. Do the workdays of the various urban high school assistant principals differ?

The investigator, in the nonparticipant observor role, employed five data-collection techniques: field notes; structured interview; review of written materials; and structured observation, employing the framework of Mintzberg (1973), whereby chronology, written communication, and verbal contact records were kept. The sample was composed of five assistant principals, representing a cross-section of administrative functions, in an urban school district on the West coest. Each assistant principal was observed throughout five days and evenings of schoolrelated activities.

The worktime of the composite sample was apportioned in the following manner: six percent, telephone cal1s; 17 percent, desk work; 24 percent, scheduled meetings; 24 percent, unscheduled meetings; and 34 percent, observational/informational tours. The average work week was 42 hours and 33 minutes; the average workday, 8 hours and 31 minutes. The dimensions of brevity, fragmentation, and variety were evident in daily work. In twenty-five days, 1,280 separate activities were, undertaken. The average duration per activity was quite short: telephone calls, two minutes; unscheduled meetings, five minutes; desk sessions, nine minutes; tours, 12 minutes; and scheduled meetings, 36 minutes. Seventy-five percent of all activities lasted less than nine minutes. Only one percent exceeded an hour. The assistant principal interacted with many participant groups, with heaviest emphasis 
on subordinates within the building (64 percent of input mail, 79 percent of output communications; 49 percent of al1 verbal contacts) and clients, or students and their families (26 percent of all verbal contacts). Fifty-eight percent of all meetings and tours were with one other person. The prime purpose for interactions was to convey, receive, review, or exchange information (66 percent of input mai1, 74 percent of contacts, and 79 percent of contact time). The assistant principals initiated 54 percent of their verbal contacts and 46 percent of the number of pieces of mail received. The factors tentatively isolated as related to workday differences were physical facilities, personal style and philosophy of assistant principal, time of year, and assigned functions. 
To my parents

who live Hemingway's code of

grace under pressure 


\section{ACKNOWLEDCMENTS}

The writer is indebted to several groups and individuals. A very special thank you goes to the five busy assistant principals who hospitably accepted yet another obligation, allowing themselves to be "shadowed" throughout all their work activities over a total of twentyfive days. The Doctoral Advisory Committee was also extremely helpful. Particularly valuable were the support of my chairperson George Timmons and the advice of Nancy Pitner, as she had completed a similar study three years previously.

Both the Delta Kappa Gamma Society International and Alpha Rho State of Del ta Kappa Gamma are deserving of special recognition for their generous financial assistance over two years of study. Finally, the writer is indeed grateful for modern technology and for Hazel Taylor, whose competence as a word processor made the processes of proofing and correcting almost effortless.

Quotations from Mintzberg's The Nature of Managerial Work are reprinted by permission of Harper \& Row Publishers. Copyright 01973 by Henry Mintzberg. 
TABLE OF CONTENTS

PAGE

DEDICATION. ..............................

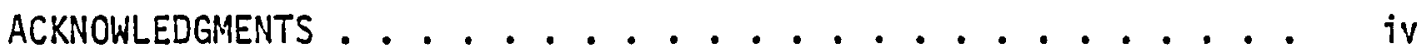

LIST OF TABLES. ................................ Vii

Chapter

I INTRODUCTION TO THE STIDDY ................ 1

Introduction .............. 1

The Research Problem ........... 3

Description of the Research. . . . . . . 4 4

Significance of the Study. ........ 5

II REVIEN OF THE LITERATURE. ............. . . 9

Introduction .............. . . 9

Managerial Work. ............ 10

observational Studies of Superintendents,

Principals ................ 15

The Manager in the Formal Organization .... 20

The Assistant Principal. . . . . . . 24

The Austin and Brown Studies

The Body of Literature on the Assistant

Principal

The Role of the Assistant Principal

Duties Performed by Assistant Principals

The Assistant Principal's Job Satisfaction

The Assistant Principals' Career Plans

The Workdays of Assistant Principals

Summary. . . . . . . . . . 50 50

III METHODS AND PROCEDURES. . . . . . . . . 52

Introduction ................... 52

Review of Literature ......... 53

General Methodological Perspectives. ..... 58

Sampling ................ 59

Data Collection, Coding, and Analysis. . . . 61

Problems Encountered by the Investigator. . . 70 
PAGE

Chapter

PRESENTATION AND ANALYSIS OF DATA ....... 78

Introduction ............ . . 78

The Sample of Assistant Principals . . . . . 78

Role and Tasks of the Assistant Principal

The Assistant Principal's Job Satisfaction

The Assistant Principal'S Career Plans

The Activities of the Assistant Principal's Workday................. 86

The Duration of the Assistant Principal's Workday. . . . . . . . . . 92

The Pace of the Assistant Principal's Workday. . . . . . . . . . 95

The Assistant Principal's Workday Interactions ........ . . . . 99

Participants in Interactions

Means of Interactions

Purposes of Interactions

Initiation and Reaction in the Assistant

Principal's Workday. . . . . . . . . . 123

Differences in the Workdays of Assistant

Principals........... 127

Job Functions

Personal Style and Philosophy

Time of Year

Physical Facilities

Workday Parallels of Superintendents,

Principals, and Assistant Principals . . . . 134

Activities

Duration of Workday

Pace

Interactions

Initiation/Reaction in the Workday 
PAGE

Chapter

SUMMARY AND CONCLUSIONS . . . . . . . . . . 138

Introduction ............. 138

Surnmary of Results............. 139

Activities of the Assistant Principal's Workday

Length of the Assistant Principal's Workday

Pace of the Workday

The Assistant Principal's Interactions

Initiation and Reaction in the Assistant Principal's Horkday

Workday Differences of Assistant Principals

Workday Parallels of Superintedents, Principals, and Assistant Principals

Recommendations for Researchers and

School Administrators. . . . . . . . .

Observational Studies of School Administrators

Exploration of Proactive and Reactive Work in Formal Organizations

REFERENCE NOTES ..................... 149

BIBLIOGRAPHY. . . . . . . . . . . . . . . 150

APPENDIXES. . . . . . . . . . . . . . 157

Appendix A - Structured-Observation Forms. . . . . . 158

Appendix B - Interview Schedule. ............ 162

Appendix C - Chronology Records. ............ 164

Appendix D - Input Mail Records. ........... 170

Appendix E - Output Mail Records ........... . 176

Appendix F - Contact Records . . . . . . . . . . 182 


\section{LIST OF TABLES}

I A Chronology Record .............. 67

II A Written Communication Record. .......... 68

II A Contact Record. . . . . . . . . . . . 69

IV Analysis of the Chronology Record . . . . . . . 88

$\checkmark$ Comparison of Proportion of Time Devoted to Activities by Assistant Principals and Mintzberg's Chief Executives. ...............

VI Duration of the Work Week and Workday of Assistant Principals. ............. 93

VII Comparison of Indicators of Brevity/Fragmentation in the Workdays of Assistant Principals and Mintzberg's Chief Executives. ..............

VIII Analysis of the liail Record: Input . . . . . . . 99

IX Analysis of the Mail Record: Output.......... 101

$X$ Analysis of the Contact Record. .......... 103

XI The Assistant Principal's Interactions: Sender/ Target of Written Communications and Participants in Verbal Contacts. ............ 106

XII The Assistant Principal's Contact Time with Participants External to and Internal to the

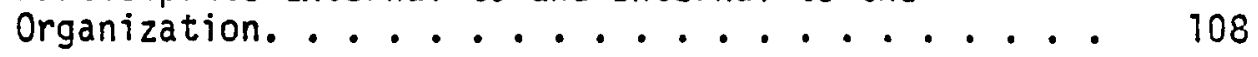

XII Numbers of Participant Groups Involved in the Assistant Principal's Scheduled Meetings, Unscheduled Meetings, and Tours .........

XIV Total Numbers of Participants Involved in the Assistant Principal's Verbal Contacts . . . . . . 112

XV Size of the Assistant Principal's Meetings and Tours. - 113

XVI The Assistant Principal's Mail: Receipt and Initiation. . . . . . . . . . . . . . 
PAGE

TABLE

XVII Purposes for the Assistant Principal's Hritten Communications. .......... 117

XVIII Purposes for the Assistant Principal's Verbal Contacts. ............... 118

XIX Discrepant Proportions in the Comparison of the Mail Purpose Categories for Assistant Principals and Mintzberg's Chief Executives . . . 122

$X X$ Discrepant Proportions in the Comparison of the Contact Purpose Categories for Assistant Principals and Mintzberg's Chief Executives . . . 122

XXI Proactive/Reactive Aspects of the Horkdays of Assistant Principals and Mintzberg's Chief

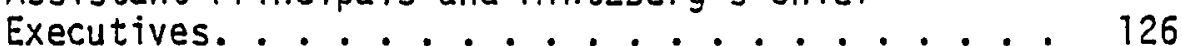




\title{
CHAPTER I
}

\author{
INTRODUCTION TO THE STUDY
}

\section{Introduction}

The position of assistant principal is an ubiquitous one in American high schools. It is also a job of importance in the administration of secondary schools, as the person filling that post has at least some responsibility for nearly every aspect of day-to-day operations (Austin \& Brown, 1970, p. 53). Further, it is often the entrylevel position for aspiring educational leaders--for those seeking a secondary principalship or central office line administration, including the superintendency.

While the assistant principalship is central to school administration, the literature relative to the position is disappointing. Information regarding the assistant principal, as derived from the literature, is somewhat inconclusive and fragmentary; and a tone of dissatisfaction with the status quo characterizes many writings. For example, the assistant principal's role description is considered vague, as the following comment illustrates:

It might be assumed that the role of Assistant Principal... is one which has been reasonably well defined. Not so! A survey of the limited literature on the role of Assistant Principal convinces one in short order that the role is extremely variable and rather poorly defined. Assistant Principals are first, what they think they are; second, what other colleagues think they should be; and third, what the organization wants them to be. (Greenham, 1972, p. 27) 
The major tasks specifically assigned to the assistant principal, frequently centering around the pupil personnel responsibilities of attendance and discipline (Austin and Brown, 1970, p. 18), have led many professionals to decry the narrow stereotypes of the post (Bevan et al, 1973; Bordinger, 1973; Greenham, 1972; Hurley, 1965; Mazzei, 1976). Job assignments, in turn, seem to lead to both job dissatisfaction and a desire to advance beyond the assistant principalship, as Austin and Brown (1970) pointed out:

We have evidence from our study that only one-fourth of the men and half of the women see this position of assistant principal as constituting a desirable career assignment.... The problem is not one of salary; this is clear. It is, rather, the unpleasant negative stresses, the inability to see things through, the "trivialities" or minor tasks that are of great importance to others but that provide the incumbent with little sense of fulfillment--these are identified as the major sources of low levels of job satisfaction. (p. 82)

The challenge for a researcher concentrating on the position of assistant principal is, thus, evident: to design an appropriate research methodology for providing an integrated view of the assistant principal's everyday work activities. Such a description would serve as a research context from which more precise role descriptions might emerge and would also provide the basis from which plans for positive modifications of the assistant principalship could be developed. Most importantly, although the problems surrounding the assistant principalship have received literature exposure, only one attempt at a coherent description of the basic work and workday (Austin and Brown, 1970)--the groundwork for analysis of any administrative post--has previously been available to students, researchers, or practitioners of educational administration. 
The Research Problem

The central problem of this study was to determine the nature of the everyday work of the assistant principal in an urban high school. Subproblems are indicated by the following questions:

1. What are the workday activities of an assistant principal?

2. How long is this day?

3. How might the pace of the workday be described?

4. With whom does an assistant principal interact? How? Why?

5. To what extent is daily work proactive? Reactive?

6. Do the workdays of various urban high school assistant

principals differ in terms of content, duration, pace, contacts, degree of work initiation? If so, what might account for such differences?

The following objectives, then, concisely state the research problem:

1. To investigate the nature of the urban high school assistant principal's day by collecting and analyzing observational and structuredinterview data on the work of five high school assistant principals in an urban school district, supported by a systematic analysis of the relevant literature.

2. To develop from this investigation a description of the urban high school assistant principal's workday (the activities, length, pace, contacts, degree of self-initiation, and workday differences) and to compare this workday description to the descriptions of principals' and superintendents' workdays derived from the literature. 


\section{Description of the Research}

The research problem was addressed by directly observing the behaviors of five high school assistant principals in a West coast urban school district for 25 school days and work evenings. The investigator, in the role of nonparticipant observer, collected data by means of:

- Field notes

- Reviews of documents and correspondence

- Structured observations

- Structured interviews

The research study is reported as follows:

Chapter II contains a review of the literature, describing and analyzing the contributions of managerial work researchers, researchers who have conducted observational studies of other educational managers, formal organization theorists, and writers focusing specifically on the assistant principal.

Chapter III presents the literature relevant to field study research methodology; the research methods and procedures: the sampling and data collection procedures, with emphasis on the recording and coding of observations on the Chronology, Communication, and Contact records; and the problems encountered by the investigator.

Chapter IV contains a presentation and analysis of the data: discussion of the similarity of the sample to other assistant principals, the results of the study in terms of the six research sub-problems, and comparison of the woriday description of the assistant principal to the available workday descriptions of school principals and superintendents. 
Chapter $V$ contains a summary of the study procedures, the findings for each of the six research questions, and the investigator's recommendations to researchers of educational administration and to prospective and practicing school administrators.

\section{Significance of the Study}

There is a need for observational studies regarding the day-to-day managerial activities of assistant principals. The vice-principal position is almost always a part of the administrative structure of American secondary schools with enrollments of more than 500 (Austin and Brown, 1970, p. 26). Furthermore, Austin and Brown have stated, "To great numbers of adults and young people who populate our secondary school communities, the assistant principal is the person who really runs the school" (p. 1). And yet, the literature concerning this position is sparce. Austin and Brown maintained the following:

In spite of the acknowledged importance of the assistant principal as a chief support of the administrative structure in 211 but the smallest schools, the position has been a forgotten stepchild so far as administrative study and research are concerned. ( $p .1$ )

The need for more research grows as many assistant principals are experiencing job dissatisfaction and are moving on to even more responsible posts in education (Austin and Brown, 1970, p. 78). These trends carry implications for recruitment, selection, and training, which are best done only when the job is understood well. 
The nature of the assistant principal's workday must be properly described before aspirants will be able to make informed decisions about whether to take the first step into the hierarchy of secondary school administration. They need to know what the work is, rather than merely the job dissatisfactions and resulting "shoulds" and "oughts" described in the literature. A realistic description of the assistant principalship also is necessary for those who hire and train assistant principals. They need to select and educate in a manner appropriate for the assistant principalship; and by fulfilling those two functions, they may determine the quality of a future principal or superintendent. The hiring and training responsibilities are particularly onerous in today's urban school systems. Given the combination of declining enrollment and diminishing financial resources in cities, fewer assistant principals will advance beyond their entry-level positions. Thus, neither the position nor the person can be revitalized simply by the turnover and the advancement of the past. Further, the pool from which principals and central office administrators will ultimately be selected will be smaller, since the numbers moving in and out of the entry positions will decrease over time.

Livingston (1971) raised questions specifically regarding the efficacy of management training programs. He stated explicitiy, "Managers are not taught in formal education programs what they most need to know to build successful careers in management" (p. 79). Livingston concluded, "Their failure is due, in fact, to the fact that many crucial managerial tasks are not taught in management education programs but are left to be learned on the job, where few managers ever 
master them because no one teaches them how" (p. 88). Leu and Rudman (1963) also specified a major shortcoming in the preparation of managers for the educational settings: "A whole collection of administrative folklore has grown up through the years.... But the problem still remains of building administration into more than a bag of tricks, more than a mystical set of mores from which the 'trained' administrator is to operate" (p. $x)$.

The underlying problem may be, as Mintzberg (1973) inquired, "If we do not know what managers do, how can we claim to teach management?" (p. 3). Mintzberg argued as follows:

We can no longer afford to ignore managerial work as an area of research. It is the researcher, feeding knowledge to the manager and management scientist, who will ultimately determine the ability of our large bureaucracies to cope with their immense problems. (p. 198)

Observation methodology offers an effective means for building a coherent description of the assistant principal's workday. Austin and Brown (1970) contended that, of the three methodologies employed for the study of the assistant principalship, "The one that seemed most productive and most promising for further and deeper understanding of the dynamics of the administration of school-in-progress was the one that employed the shadow interview technique" (p. 75). The need for augmenting the only major study on the assistant principalship of such a socio-anthropological nature also is clear from Austin's (1972) observations: "The roles of assistant principal and principal are undergoing drastic changes in a large portion of our schools. If this be true, another decade should include further research relative to more specific relationships within these changing institutions" (p. 71). 
By using the observational technique, it also would be possible to add to the small but significant and growing body of literature on the manager's work, both in business and in education. Mintzberg (1973) observed and described the nature of the workdays of five chief executives. Pitner (1978) employed the Mintzberg framework for a descriptive study of the everyday activities of suburban superintendents; Crowson and Porter-Gehrie (1980), for an observational study of urban principals. Peterson (1978) also observed and analyzed the daily work of elementary principals. Adding a similar investigation of the assistant principal's workday would, thus, fill a void in the literature of educational administration. 


\section{CHAPTER II}

\section{REVIEW OF THE LITERATURE}

\section{Introduction}

The study of a school manager, whether it is at the level of an assistant principal or a district superintendent, is embedded in the general context of management study. The investigator, therefore, turned to the management literature of formal organizations, in business and industry as well as in education, to provide the foundation for studying the urban high school assistant principalship. The study of leadership as a phenomenon dominates much of this management 1iterature. And yet McCall (1977) contended, surveying the leadership writing is like "skipping through a minefield" (p. 375). McCall pointed out shortcomings involved in both traditional and contemporary approaches to leadership. He proposed that it may be a more promising emphasis for future management research to identify the everyday activities of people who occupy leadership roles, rather than to study leadership itself. Thus, the writer began to analyze the contributions of researchers on day-to-day managerial work: a small group consisting basically of Carlson (1951), Burns (1954), Guest (1956), Dubin and Spray (1964), Stewart (1967), and Mintzberg (1970, 1971, 1973, 1975).

Another emphasis in the literature review consisted of observational studies of educational managers, specifically the principal and 
the superintendent. Pitner (1978) employed the Mintzberg (1973) framework for observation and categorization of everyday managerial activities in a descriptive study of the suburban superintendent. Crowson and Porter-Gehrie (1980) conducted a series of observational studies on urban principals, also using the procedures developed by Mintzberg (1973). Wolcott (1973) and Peterson (1978) observed the behavior of elementary school principals.

Contributions from the formal organization literature were then examined for their relevance to the study of managers' workdays. Formal organization concepts--specifically, uncertainty and bounded rationality (March \& Simon, 1958) and conflict--were examined for their relationship to the findings of managerial-work researchers in both the business world and in educational. institutions.

The final portion of the literature review was narrowed to the assistant principalship, in an attempt to ascertain the status of research knowledge regarding that position. Due to the scarcity of available readings, the investigator chose to present and analyze an array of topics dealt with in the literature regarding the assistant principalship: demographic characteristics, role, tasks, work satisfactions and dissatisfactions, relations between principal and assistant, and career planning.

\section{Managerial Work}

Mintzberg's writings (1970, 1971, 1973, 1975) are central to the study of the manager's actual work. In 1967-68, Mintzberg conducted his Ph.D. thesis study, entitled The Manager at Work--Determining His 
Activities, Roles and Programs by Structured Observation, reported in The Nature of Managerial Work (1973). The major purpose was to identify the work content similarities of five chief executives, through one week of shadow observation of each man. Data collected on observed managerial activities were presented in Chronology Records, Communication Records--both mail input and output, and Contact Records. The results of this study, along with the results of the major diary studies of Carison (1951) and Stewart (1967), led Mintzberg (1973) to develop propositions on the characteristics of managerial work. Selected propositions are as follows:

- "Because of the open-ended nature of this job, the manager feels compelled to perform a great quantity of work at an unrelenting pace" (p. 51).

- Managerial activities are characterized by "brevity, variety, and fragmentation" (page 51).

- Apparently, managers actually choose brevity and interruption in their work (p. 51).

- Managers move toward the more active demands of their work-"the current, the specific, the well-defined, the nonroutine activities" (pp. 51-52).

- The majority of a manager's time is devoted to verbal contacts (p. 52).

- "The manager may be likened to the neck of an hour glass, standing between his own organization and a network of outside contacts" (p. 52). 
- The manager's work is comprised of both duties and rights: though many activities appear to be reactive, the manager can also exert control (p. 53).

The diary studies of Carlson (1951) and Stewart (1967), cited previously, provided the background of Mintzberg's work (1970, 1971, 1973, 1975). The purpose of Carlson's research on the work of nine Swedish company presidents was to isolate basic patterns of behavior. He analyzed diaries consisting of the managing directors' self-recorded daily activities. For each activity, the managers were asked to record location, contacts involved, communication techniques employed, topic dealt with, and action taken.

Carlson (1951) concluded, as did Mintzberg, that the workloads of managers are demanding and that uninterrupted time is rare (Chap. 4). Perhaps Carlson's (1951) most understated and yet most unique contribution as a managerial work researcher was the identification of psychological and social implications of the manager's workload: "For the chief executives themselves this excessive working load has many unpleasant effects" (p. 75). Among these negative effects are limited opportunities to interact with family and friends; evenings and weekends consumed by office work; isolation from contemplative, intellectual, and cultural life (p. 75). A Fortune magazine study (Whyte, 1954) echoed these concerns. Whyte noted the onerous workload, the growing numbers of contacts, and the escalating stress-level in executive work. He also observed, "For the corporation man, the balanced life is as elusive as ever" (p. 108). The executive is isolated when at work, but has little. time to devote to family. And yet, "Of executives questioned, 90 percent say they did not work too hard" (p. 148). 
Stewart's (1967) diary study of the time expenditure of 160 managers yielded findings similar to Mintzberg's (1973). First, managerial work was verbal in nature. On an average, half of management time was spent in discussions ( $p .43$ ). On an average, 26 percent of total contact time was devoted to subordinates; 30 percent to peers and others; and only eight percent to superiors; with 34 percent of total work time spent alone (Chap. 3). Finally, a high degree of work fragmentation was found. For example, in four weeks of diary entries, a mean of only nine occasions of uninterrupted periods of one-half hour or more were available to the manager (Figure 23, p. 72).

In Burns' study (1954), four British middle managers who worked closely with one another kept individual diaries of how their time was spent over a five-week period. Again, a major finding was that a substantial segment of their time was devoted to conversational contacts. Burns concluded that much of this communication took place with a small group of colleagues, or other managers. Burns also concluded that managers' judgments regarding allocation of time are frequently in error.

Dubin and Spray (1964) studied two weeks of diary records of eight American managers, some considered junior executives. The higherlevel managers were less likely to concentrate on one activity. Communication face-to-face, rather than by telephone or writing, was prevalent. They tended to initiate their contacts and to do so more frequently with a subordinate than with a superior. Of contacts witnin the organization, one-third to two-thirds were with subordinates; one- 
fifth to three-fifths were with associates and peers. The proportion with subordinates decreased, and the proportion with peers increased, for executives lower in rank. Higher-level executives and those in client-centered organizations were found to be more frequently involved in external contacts.

Guest (1956) is representative of researchers other than Mintzberg (1973) who reported results of observational studies of managers' days. Guest observed 56 foremen for a day each. An analysis of activity records yielded the following conclusions, which are again quite similar to Mintzberg's propositions on the characteristics of managerial work:

- The day is frenzied. Subjects participated in from 237 to 1,043 activities per day, with incidents changing every 48 seconds. Many critical problems were handled simultaneously. The manager was interrupted again and again.

- Another hallmark of the job was the great number and variety of contacts a foreman had in a single day; often, in fact, the frequency was more than 50 daily.

The foregoing studies of day-to-day managerial work have contributed significantly to the literature on management, by concentrating on the reality of managers' workdays rather than prescribing what the days, weeks, months, and years of life in management ought to be. However, these studies are inadequate descriptions of the managerial work of the assistant principal. First, the diary studies raise serious questions regarding the methodology most frequently used. As Burns (1954) pointed out in his study of British mid-level managers, selfrecorded information may be inaccurate. Mintzberg (1970) asserted 
another disadvantage of the diary method: "Managerial work is extremely hectic and complex and it frequently comes in short, dense bursts. The manager is far too busy to record properly" (p. 104). Secondly, even the most recent work, Mintzberg's (1973) 1967-68 Ph.D. thesis study, is a decade old; the early work of Carlson (1951) dates back thirty years. Finaliy, a matter of particular concern to this investigation: neither the work arena nor the level of management position studied has often been that of the assistant principal. Assistant principals are not chief executives. Further, the assistant principal operates in the public sector; whereas, many of the foregoing studies are rather firmly rooted in private sector business and industry.

\section{Observational Studies of Superintendents, Principals}

There are, however, studies, some modeled on the foregoing work, that have concentrated on the public sector education manager. Pitner's (1978) observational study of three suburban school superintendents, while based on the propositions and categorization techniques of Mintzberg (1973), went beyond the Mintzberg work to focus on the superintendent's management of information and interaction in the social system. She determined that the contributions of statutes, board rules and regulations, and the professional literature relative to the superintendendency inadequately described the work of superintendents.

Pitner (1978) employed various research methods, including structured interviews, review of documents, anecdotal reporting, and structured observation. One week of observations of each chief school executive resulted in chronology, mail, and contact records as found in 
Mintzberg's study of five chief executives (1973). However, two aspects of Mintzberg's work--his development of management role classifications and his views on non-rianagerial work--were legitimately questioned by Pitner.

In addition to delineating the managerial work propositions, Mintzberg (1973, Chap. 4) also specified what he viewed as the manager roles, derived from analyzing the purposes for the activities undertaken by the five chief executives. The ten roles, he contended, together form an integrated view of managerial work, but can be subdivided into three major categories: the interpersonal roles, the informational roles, and the decisional roles. Pitner (1973) termed Mintzberg's (1973) thinking an "equivocation of 'role, purpose, and function" (p. 74). The following is persuasive:

For instance, the negotiations purpose becomes the negotiator role, the problems purpose becomes the disturbance-handler role, and the giving information purpose becomes the disseminator role...It is unenlightening to simply take the categories and relabel them. (p. 74)

Pitner (1978), in addition to challenging the defensibility of Mintzberg's (1973) role classifications, asserted, "Close analysis of his purpose categories is in order" (p. 75). She illustrated her concern regarding the confusion of Mintzberg's purpose classifications by reference to certain of his mail purpose categorizes, such as authority requests, reference data, and problems and pressures. While Mintzberg presented all as example purposes for a manager's written communications, Pitner clearly raised a significant problem regarding the purpose term when pointing out that ai though authority request refers to a mail pur- 
pose, reference data and problems and pressures instead denote how a piece of mail functions in the manager's organization (pp. 75-76). The question of designation of work as managerial or nonmanagerial was also addressed by Pitner (1978). She contended that Mintzberg's (1973) "accounting for 100 percent of the manager's time in the chronology record" (p. 72) is likely inaccurate:

This figure must represent either (a) 100 percent of managerial time in which case Mintzberg must have ignored what he took to be nonmanagerial activities, and in which case he does what he accuses Drucker of having done; or (b) the figure of 100 percent represents the total time spent "on the job." If this is the case, then Mintzberg must hold that everything the manager does is managerial, but this is quite a difficult position to hold. It appears that managers are, for the most part, typical human beings with families to attend to, errands to run, friendships to pursue, and meals to eat... (p. 72)

The conclusions of Pitner's (1978) study were also, to some degree, in conflict with Mintzberg's (1973) propositions. For example, Mintzberg concluded that executives devote from one-third to one-half of their contact time to external contacts (p. 52); in contrast, Pitner found that 73 percent of the superintendents' contact time was with members of the organization and only 27 percent with people external to the school district (p. 110). In addition, Pitner determined that, "While superintendents are busy, the superintendent does not maintain an unyielding pace of activities. He experiences periods of intensity and variety as well as depressed cycles of activity" (p. 99). This is surely a somewhat modified statement from that of Mintzberg: "The manager feels compelled to perform a great quantity of work at an unrelenting pace" (p. 51). Many of Pitner's (1978) conclusions, however, echoed those of Mintzberg (1973). The agreed-upon indicators of managerial work were as follows: 
- Brevity, variety, and fragmentation ("The superintendents' activities were generally brief and fragmented; 60 percent lasted less than 9 minutes, and 6 percent exceeded one hour" [p. 166].)

- Numerous verbal contacts ("The superintendent's world is largely verbal; subject superintendents spent 80 percent of their time in verbal contacts with others" [p. 165].)

- A blend of constraints and opportunities (p. 120)

One of the classic observational studies of a school administrator's work was that of Wolcott, described in The Man in the Principal's Office: An Ethnography (1973). Wolcott found an abundance of literature on what administrators ought to do, but a dearth of research on what they actually do. Wolcott "shadowed" an elementary school principal in a Pacific Northwest community for a full year. Several of Wolcott's (1973) conclusions parallel those of other managerial work research studies:

- The principal participates in myriad interactions and encounters. He is a meeting-goer. He negotiates conflicts. He deals with one emergency after another.

- Interruptions are a constant reality; and if the principal is not interrupted, he often chooses himself to initiate a new activity (Chap. 11).

Although Mintzberg (1973) and Pitner (1978) viewed the manager as serving under constraints as well as free to create opportunities, Wolcott (1973) concluded that the constraints restrict the principal from exercising much leadership. Because of policy directives from superiors, the necessity for compromise, and teacher movements, the principalship may well be the point of least change (Chap. 11). 
Peterson's observational study of two el ementary principals (1978) was also predicated on the contention that the literature on the principal was normative in nature, rather than directed toward the actual workdays of principals. As a result, his study was designed so that administrative behavior could be observed and analyzed. Peterson determined that the principal's day was characterized by numerous, varied, brief activities. The principals, in fact, participated in an average of 13 activities an hour; eighty-five percent of the activities lasted less than nine minutes. The tasks undertaken by principals were predominately $(60 \%)$ self-initiated, though the 40 percent of otherinitiated tasks often were dealt with first. The investigator speculated that the pace of the workday and the number of reactive behaviors required within the day led to a "decision-press": "The immediacy and variability of tasks may place the principal in a situation in which numerous unexpected decisions with differential cognitive and affective requirements have to be made quickly and carefully" (p. 2).

Dther observational work on the principalship has been conducted very recently by Crowson and Porter-Gehrie (1980). Ten principals were selected from the same urban school system; the sample was balanced in terms of elementary and secondary schools, inner- and outer-city schools, and large and small schools. Each principal was observed for 12 days and evenings of work, and activity records were kept. In addition, school records and documents were studied.

Crowson and Porter-Gehrie (1980) agreed with Mintzberg that the managerial day consists of a variety of brief tasks and inte:actions. The principals' activities ranged from one to more than 30 per hour, 
with an average of ten. "More than one-fifth of all activities lasted just one minute or less; nearly half (48\%) of the principals' time was spent in activities lasting less than four minutes" (p. 51).

This study (1980) examined specifically the discretionary decisionmaking behavior of the principal. The investigators stated, "The data and findings thus far indicate that principals do exercise discretion in the day-to-day delivery of the services of their schools" (p. 49). However, the problems inadequate resources, authority challenges, an ambiguous role) that Crowson and Porter-Gehrie found lead to various administrative coping mechanisms place constraints on this freedom of decision.

\section{The Manager In The Formal Organization}

A manager's day is described in the administration literature as marked by tremendous workload, hectic pace, brevity and fragmentation of activities, great variety, numerous interruptions, a "now" orientation, myriad verbal interactions, both restriction and freedom. Perhaps most provocative is the notion that this work content and style may we 11 be self-imposed.

Similar conclusions have been reached by a small group of educational researchers. Education and business managers appear to experience variety, brevity, fragmentation, emphasis on verbal contacts, and a combination of constraints and responsibilities. If these similarities are attributable to formal organization structure in business/ industry and education, the literature of organizational theory should be explored. Davis and Luthans (1980) lend support to this view, having 
stated, "We contend that the organizational environment that influences and controls managerial behavior has been badly neglected" (p. 67).

Of the many concepts discussed in the literature of formal organizations, three were selected for exploration: uncertainty, bounded rationality, and conflict. Each has been a focus for one or more observors of formal organizations in education. In fact, these three concepts describe some of the most troubling aspects of the administration of modern educational institutions, particularly those in urban centers.

The open milieu (Thompson, 1967) of a contemporary complex forma] organization is one of uncertainty (March and Simon, 1958). Cohen and March (1974) have, in fact, described the organizational context of university presidents as "organized anarchy." They (1974) contended that though planning is traditionally viewed as a major executive function, little planning is actually done, since rational planning assumes goal clarity, clear understanding of the organization's technology, and continuity in leadership--all assumptions that are frequently not met in complex modern organizations. March and Simon (1958), in fact, rejected the Western notion of rational action and substituted the concept of a rationality that exists within the cognitive linits of human being. All possible alternatives are not known, nor are all of the consequences of these alternative choices; therefore, a decision can only "satisfice."

If the work environment is fraught with uncertainty and humans are by nature limited in their cognitive capabilities, the most comfortable solution for the manager is likely to concentrate on immediate matters and to avoid what is more long-term and threatening. Illustrative of 
this would be the contention of Cohen and March (1974) that university presidents are more likely to give attention to problems that arrive early than those that arrive late (Chap. 5).

A sizeable portion of Pitner's dissertation (1978) on the suburban superintendent was devoted to the school chief as a manager of information. "By information manager it is suggested that the superintendent controls the acquisition, retention, and dissemination of information" (p. 123). Pitner described how the information manager reduces the uncertainty and anxiety within the organization and its environment:

The superintendent as interpreter of organizational history.... Out of all the facts which are available, he selects those which explain, justify, or legitimize things that are going on in the present, thereby reducing uncertainty for others. The superintendent reconciles the present with the past. The manager not only uses the existing history, he creates an historical record for the organization. (p. 129)

The superintendent as contemporary interpreter.... The superintendent as an active perceiver of the contemporary world may selectively notice different aspects of the environment, he appraises what he sees in terms of his own past experience, and evaluates what he experiences in terms of the organization's needs and values. ( $p .130$ )

The superintendent as a manager of meaning.... The superintendent provides a definition, sometimes quite by fiat, so that conceptual difficulties or issues are avoided or resolved. ( $p .131)$

The superintendent as a manager of myths.... The superintendent's utterances, writings, public beliefs, and ideas will be taken to be mythological in character when they function to: (1) create or maintain social solidarity, (2) reduce uncertainty for organizations members, or (3) legitimize social institutions and poicies. (pp. 132-134)

Whyte (1954) stated that the burden of manager workload may be due to a growing rate of contacts, and the literature on formal organizations reinforces this idea. March and Simon (1958) spoke of individual conflict, intergroup conflict, and inter-organizational conflict. Blau and Scott (1962) noted the conflicting demands of the organization's 
environment. Thompson (1967) described the organizational environment as pluralistic, burdening the organization itself with both constraints and contingencies. Spindler (1973) viewed the principal as performing a balancing function: "The administration, and particularly the school principal, is caught squarely in the midst of the value conflicts that swirl around his position and the activity of the institution that he administers"; the school organization is, in fact, conflict-permeated (p. 239).

It is clear that one responsibility of managers in a formal organization is coping with both internal and external conflicts. Organizations normally experience some degree of conflict. Managers deal with the conflicts related to the divisions and programs for which they are directly responsible, and if problems originate at lower levels and cannot be resolved there, those problems too may ultimately reach managerial levels. The resulting conflict-resolution contacts may be selfinitiated or initiated by others. It is possibly this conflict/contact cycle that contributes a great deal to the description of a manager's demanding workday: conducted at a rapid pace and consisting of great variety, with numerous brief contacts and interruptions. The manager must often work diligently to keep up with the conflicts which require attention from management. However, organizational theorists (Parsons, 1960; Spindler, 1973; Thompson, 1967) viewed reactions to conflict as part of a natural process, hopefully leading to organizational maintenance, survival, homeostasis, or system defense against the threat of organizational disruption. 
The related concept of "coping mechanisms" provided the basis for the study of the principal's discretionary decision-making behavior, by Crowson and Porter-Gehrie (1980). Lipsky's (cited in Crowson and Porter-Gehrie, 1980) notion of the street-level bureaucrat was employed for this study. The street-level bureaucrat, because of organizational and environmental complexity and uncertainty, develops simpiifications and routines that al low one to cope. Crowson and Porter-Gehrie found that the urban principal also responds to constraining forces--a lack of resources, ambiguity and contradiction in role expectations, authority challenges--by developing "coping mechanisms." For example, the principal uses "on the spot decision-making to save time"; employs "spotlighting" to "simplify a complex situation by responding to one aspect while letting other aspects drop" (p. 51).

The characteristics of formal organizations, thus, contribute background for the profile of a manager's activities found in a synthesis of the literature on managerial work research and on observational studies of educational leaders. Spindler (1973) made this point succinctly in regard to education managers: "It is apparent that the formal organization--the large unified school district or urban school system--within which the school administrator operates is in itself one of the most important determinant forces affecting his role" (p. 248).

\section{The Assistant Principal}

While many of the studies cited in the foregoing pages have concentrated on top-echelon administrative positions, a study entitled 
"The 'Assistant-to' in Four Administrative Settings" (Whistler, 1960) provides some information regarding one type of assistant manager. Though the "assistant-to" functions in a staff advisory role and the assistant principal instead has line authority, both are managers who work for and with a higher-level manager.

Whitler reported the results of interviews with 36 former "assistants-to" from the military, federal government, and city management. A key word in the conclusion statements was information. Because the chief executive's power and effectiveness depends upon adequate sources of information, the assistant was referred to variously as an information exchange agent, a public relations person, a reporter, a 1iaison--with the public and with subordinates:"He [the assistant-to] is often influential, his influence stemming from his being interposed in the line of information transmission between a person of high authority and those of lesser authority" (p. 207). This view of the importance of information access has, of course, been emphasized by Mintzberg (1973) and Pitner (1978). Mintzberg contended that interpersonal contacts lead to information which results in increased decision-making ability; without any of these three components, a manager's role cannot be integrated (Chap. 4). Pitner focused on the school system superintendent as a manager of information.

As the "assistants-to" spend so much time communicating for their superiors, the personal relationship between executives and their assistants becomes extremely important. Whistler (1960) described it:

Although they seldom stated the point directly, assistants-to in business in discussing their relationships with their respective bosses invariably revealed it to be a close personal relation, 
characterized by strong dependence of the man upon his chief at least in the early stages. He and the chief take trips together, spend Saturday mornings and weekday evenings together at the office or in the chief's home. The assistant-to frequently displaying an almost worshipful attitude toward his chief, clearly operates in his superior's shadow, relying almost entirely upon his chief's power for his own achievement. (p. 186)

However, Whistler (1960) also indicated that this executive/ assistant-to dependence does not necessarily preciude the assistant-to's desire for advancement. "Most of them [government assistants-to], like their counterparts, see it as a step on the way up, but something to be left behind eventualiy" (pp. 200-201).

The Austin and Brown Studies

The most extensive studies specific to the assistant principal are reported by Austin and Brown, in Report of the Assistant Principalship, Volume 3: The Study of the Secondary School Principalship (1970). The monograph was third in a series of National Association of Secondary School Principals research studies of public school administrators: the senior high principal, the junior high principal, and the secondary. assistant principal. Three types of research were conducted on the assistant principalship: a shadow study, a normative study, and a career study. Because of the quality and comprehensiveness of Austin and Brown's research, particularly when compared to much of the other literature on the assistant principalship, their work is cited extensively in the following pages.

In the "shadow" study (Austin \& Brown, 1970), 16 assistant principals were each observed for one week. Their ages ranged from 34-58 years, their tenure in the position of assistant principal from 1-29 
years; all but two held master's degrees (Table II-3, p. 16). Selected school sites in eight states represented a stratified random sample of seven regions of the United States and a diversity of school sizes, grade ranges, financial resources, and community characters (pp. 12, 14). In addition to shadowing, data were collected from diaries kept by the assistant principals and from interviews with students, teachers, the principal, and the assistant principal. The findings included the following:

- The largest group of day-to-day events consisted of face-toface verbal contacts with one other person (p. 19).

- The reaction/initiation nature of the assistant principal's day was a bit difficult to specify. Many activities were self-initiated; however, these activities frequently resulted from events with which the administrator had no initial involvement. The median of self-initiated events was fifty percent (p. 1 1 ).

- Practically all assistant principals were identified with attendance and discipline duties (p. 18).

- The assistant principal was often the person who kept the school operating. "It is clear that for most people in most secondary schools the assistant principal occupies a position which is not well labeled by titling it 'assistant to' anyone or anything" (p. 23).

In the normative study segment of the NASSP studies (Austin \& Brown, 1970), questionnaires were developed to ascertain the assistant principal's administrative duties. Stratified random sampling was employed, whereby 20 percent of the schools in each of the six size categories in each state were invited to participate (p. 25). Approximately 
1,000 secondary principals and 1,000 secondary assistant principals responded to these questionnaires ( $p .25)$. The responding assistant principals were found to be 45 years of age or younger in more than 50 percent of the cases; to possess master's degrees 95 times out of 100; and to have served as assistant principal six or less years in 50 percent of all cases (p. 29). Women did not hold many of these posts; in fact, 80 percent of the assistant principal respondents said that their administrative team consisted solely of men (p. 29).

The survey questions related to 59 administrative tasks, originally built around six major categories: school management, staff personnel, community relations, student activities, curriculum and instruction, and pupil personne1. Respondents were asked to indicate:

- The tasks for which the assistant principal has responsibility

- The level of this responsibility

- The importance of the assistant principal's duties to the total school's operations

- The degree of discretion allowed in fulfilling these obligations

"The findings of the normative study corroborate the common observation that an assistant principal in an American secondary school has his hands in practically everything that goes on in the school" (Austin \& Brown, 1970, p. 46). It was found that assistant principais as a group were responsible to some degree for all six categories, all 59 tasks (p. 31). The assistant principals were "generally caught up in practically all aspects of the administrative processes of their schools" ( $p$. 34); however, the level of responsibility was not at all uniform. Responsibility for tasks was rarely complete; more often it was "slight" 
or "shared" (p. 46). For only 16 of the 59 duties was the assistant principal considered to have a high level of discretion by 60 percent or more of those responding (p. 47).

Although the authors hesitated to refer to the following tasks as

"the core" of the assistant principalship, the list (Table III-13, p. 38) does reflect the duties for which, in the majority of schools, the assistant principal was perceived as having full or shared responsibility, a high level of discretion, and an important contribution to make to school functioning:

- Schoor Management

- Special arrangements at opening

- Emergency arrangements

- Staff Personnel

- School policies

- Teacher selection

- Orientation program for new teachers

- Community Relations

- School public relations

- Curriculum and Instruction

- Master schedule

- Curriculum development

- Evaluation of teachers

- Providing instructional materials

- Pupil Personnel

- Pupil discipline

- Pupil attendance

- Guidance program 
The job requirements seemed to be rather consistent, regardless of grade levels served of rural, suburban or urban location. Although there were differences between these groups, the differences within a group were greater than the differences between them. (Austin \& Brown, 1970, p. 44). In reference to such differences, Austin and Brown stated, "Variations from school to school in assigning responsibility to the assistant principal are striking" (p. 46). Variance was found in all three categories of responsibility, importance, and level of discretionary behavior.

An additional finding of the normative study concerned the attitudes and relations of principals and assistant principals. Principals were found to perceive the assistant principalship more positively than did the assistant principals. "While the differences between the responses of assistant principals and of principals are seldom large, the direction of the differences is remarkably consistent. The impression created is that more principals than assistant principals have positive perceptions of the role the assistant principal plays in the life of the school" (Austin \& Brown, 1970, p. 47). Regarding the relationship between the two administrators, the authors stated, "Critical to the understanding of any assistant principalship at any time is the peculiar relationship between the principal and the assistant principal" (p. 77). The career study portion of this assistant principalship research (Austin \& Brown, 1970) was based on questionnaires received from 419 men and women who had served as assistant principals in the years 1956 and 1961 (p. 51), representing eight geographical regions in the United States 
and a blend of urban, suburban, and rural districts (p. 50).

Only one in ten respondents was a woman; the percentage of female assistant principals varied, however, by area: 5 percent, rural; 10 percent, suburban, and 14 percent, urban (Austin \& Brown, 1970, p. 53). Nineteen of every twenty respondents had earned graduate degrees, although few doctorates were represented--and those mostly in urban areas (p. 53). A substantial number of rural (54\%) and suburban (50\%) assistant principals had advanced to the position directly from the classroom, whereas, urban respondents had both served a longer waiting period and had filled an intermediate post--for example, as department chairperson-before advancement (pp. 54-55).

Factors which influenced the decision to become an assistant principal differed somewhat from motivations to teach: the service orientation remained high, but salary and status became more important considerations (Austin \& Brown, 1970, p. 64). Encouragement to advance to the assistant principalship normally came from administrators within the teacher's school district (p. 64). Promotions to the first administrative position were felt to be due to classroom teaching success and competence in performing nonteaching assignments ( $p .65)$. The amount of time actually spent in classroom teaching was not deemed to be particularly significant; nor was professional preparation, except in urban districts ( $p$. 65). Those who considered job security important experienced less upward mobility (p. 67).

In retrospect, many respondents felt a low level of satisfaction with the assistant principalship in comparison to other positions they had held. The authors (Austin \& Brown, 1970), concluded, "The satisfactions 
to be found in the assistant principalship are few and unimpressive to most who occupy this office" (p. 78). Only a minority of the responding sarmple wished to stay with the assistant principalship as a career, although more urban respondents and women were willing to do so (pp. 7071). Desire for advancement beyond the assistant principalship was due in part to frustration with the position and wanting greater leadership involvement than provided while in the disciplinarian role (p. 63).

Regarding upward mobility beyond the vice principalship, Austin and Brown (1970) found that:

- Of those responding, 44 percent had moved to another position in 1967 (p. 55); 40-50 percent had advanced--mostly to principalships-and usually within seven to eight years (p. 56).

- Promotions within a school system accounted for 74-84 percent of the advancements (p. 65).

- Fewer women than men found the assistant principalship to be a means to career advancement, al though greater mobility was possible outside the city (p. 56).

- As a rule, however, men and women coming from assistant principalships in rural areas did not get urban posts, al though the converse did occur (pp. 60-61).

- Progress beyond the assistant principal's position was slower in urban areas (pp. 58-59).

- Almost all respondents were married, often with three or more children, and assistant principals who had large families were more often advanced (p. 57). 
The authors (Austin \& Brown, 1970), synthesizing the results of all three studies, concluded that the assistant principal is an intermediary and essential to the school's functions; that the post is primarily devoted to contacts with people, the "here and now"--frequent crises; that the satisfaction associated with the position is rather low; that the relations between principal and assistant are of critical concern; and, finally, that the view of the assistant principalship as an appropriate preparation for the principalship may be a myth (pp. 75-79). Further, Austin and Brown recommended a "broad study of administration": "The lens must be broad enough to bring into view the usual elements; the organizational framework, the job descriptions, the work flows, the operations of internal and support systems, and the important consideration of human relations and human interactions" (p. 87).

In 1972, Austin, convinced that rapid changes in education merited reconsideration of certain points raised in the NASSP study, submitted a reexamination. He contended, for example, that size of school might not have been given adequate attention. The NASSP investigators (Austin \& Brown, 1970), based on the normative, career, and shadow studies, had concluded, that "the combinations and mutations of the factors found in this investigation" suggested that a single description of the assistant principal position would be impossible (p. 75). However, Austin (1972) later asserted that large-city systems appeared to define the job more specifically. lie also maintained that an increasing emphasis on human reilations with both students and community members, and on team management, might be changing the position's breadth of responsibility and style. Finally, Austin stated that his earlier comments regarding 
the possible inappropriateness of the assistant principalship as training for the principalship had been seriously challenged by both career assistant principals and those who served on an administrative team with their principals.

\section{The Body of Literature on the Assistant Principal}

Beyond the substantive NASSP study, the position of assistant principal has not been clarified by either statute or the literature on educational administration. In Oregon, for example, the statutes are silent in regard to school administrators; there are administrative rules pertaining to the job, but these only relate to certification standards (Mylnechuk, Note 1). As to the literature, Gillespie (1961) pointed out, "Little was written before 1953 concerning the role and status of the assistant principal" (p. 60). The literature remains unimpressive in volume and content.

To illustrate, the Canadian Teachers' Federation (1975, 1978) compiled two extensive bibliographies on principals and vice principals. of more than 1,000 entries, only 37 titles related specifically to the United States secondary assistant principalship. Of these, nine were concerned specifically with bargaining issues: negotiations in general, fringe benefits, salary schedules, and model contracts. of the remainng 28, one was a paper, two were available in ERIC only, seven were Ph.D. theses, and 18 were journal articles.

Of the 18 articles, 11 appear in the NASSP Bulletin--a journal focusing on advice to the practitioner, rather than empirically-based research findings and conclusions. The content is spread thinly over a variety of topics: role, tasks, challenges and problems, the future 
of the position, influence, advice to position holders, relations to or perceptions of other administrators, leadership, team management, integrity, careers, and the nature of the post in a particular state.

An ERIC search was conducted by the writer for the period 1974 to January 1980, with such descriptors as Tasks of Administrators, Job-Task Analysis, Assistant Principals. The 31 articles which surfaced, covered a diversity of concerns: the significance of the job, its crisis orientation, training for it, its relationship to the principalship, problem solving and decision-making, activities, job satisfaction, salaries, careers, women and Blacks in the position, and model contracts. An integrated conception of the assistant principalship did not result from the ERIC search. Joly (1973) made note of these shortcomings in the ERIC literature: "Information on the role of the assistant principal is so scarce.... All of these [task areas such as student activities and discipline] are parts of the roles..., of course, but summaries do not indicate any specific discussion of the assistant principals and the parts they play" (p. 16).

An analysis of The Assistant Principal: a collection of ERIC Document Resumes (1973), though clearly concentrating on the assistant principal, illustrates Joly's (1973) point. The articles referenced are almost solely concerned with the duties assistant principals may perform, such as curriculum, discipline, scheduling, and staff relations. Even these are dealt with generically. Indeed, titles of the articles often do not mention the assistant principal. Again, the position as a whole is not described. 
Sampling the literature on the assistant principalship illuminates the foregoing points. For example, Smerka's article (1980) exemplifies the practitioner advice mode found in a majority of the articles. He stressed the following ideas as "modus operandi" for the assistant principa1:

- Remember that you are the principal's subordinate and that your job is to simplify his/her work.

- Keep in mind the service-orientation of education.

- Effectiveness results from involvement.

- Appropriate communication modes should be employed.

- Keep a sense of humor and happiness.

- Assess yourself reflectively.

- Give credit to those deserving it.

- Stay positive and optimistic.

The contributions to the literature on the assistant principal can all be grouped around four major topics, all dealt with in the NASSP study (Austin \& Brown, 1970): the role of the assistant principal, the tasks associated with the position, the level of job satisfaction, and career plans. The remainder of this chapter is devoted to a review of these four subjects.

The Role of tine Assistant Principal

Novak (1963), by stating that the assistant principalship is "vaguely defined" (p. 20), is representative of many other writers (Black, 1930; Bordinger, 1973; Childress, 1973; Greenham, 1972; Jarrett, 1958; Joly, 1973; Koerner, 1973; Valentine, 1980) who have pressed for more clarity and specificity in descriptions and definitions of the 
assistant principal's role, status, goals, functions, and duties. The following legal definition (Gatti \& Gatti, 1975), perhaps understandably, represents the vagueness encountered:

The vice-principal is part of the administration and is not a part of the teaching staff while carrying out his or her administrative functions. He or she is considered an employee and not an officer of the school board. The vice-principal reports directly to the principal and is generally in charge of specific areas such as student discipline. The vice-principal is liable for his or her own acts, but not the acts of teachers unless the vice-principal knew or should have known of the potential tortious conduct. ( $p .301$ )

Even the title for the position next in line to the principal varies greatiy. Gillespie (1961) listed assistant principal, vice-principal, associate principal, department head, adviser, counselor, or dean of boys or girls. He stated, however, "Approximately 90 percent of the school systems of the country now designate the person next in authority to the principal as either assistant principal or vice-principal, with the title assistant principal being used more often" (p. 59). Jarrett (1958) recommended standard use of the assistant principal title.

The lack of a precise and consistent description of the assistant principal position can be explained partially by the historical evolution of the office. Gillespie (1961) and Jarrett 1958) contended that the assistant principalship was added to the administrative staff when schools grew in size and, as a result, in complexity for the principal. Barratt (1955) stated specifically, "Consolidation of small school districts into single large units and rapidly increasing school enrollments are largely responsible for this growth in numbers and importance" (p. 56). He enumerated reasons for employing an assistant principal. One was, "To relieve the principal of certain duties which will provide him with additional time for such necessary activities as supervision 
and professional leadership projects" (p. 56). We11s, Melson, and Johnsen (1965) traced the beginning of the assistant principalship: "For the past 40 years a new position, that of the assistant high school principar, has been emerging in the field of school administration" (p. 15). Historical explanations also come from such statements as, "The position grew like Topsy" (Hurley, 1965, p. 12) and, "The development of the role of the assistant principal has apparently followed no systematic pattern" (Garrett, 1958, p. 28).

The position's vague definition has been frequently highlighted by students of educational administration:

- "The position of assistant principal in the American secondary school has evolved without an adequate sense of direction or underlying philosophy" (Gillespie, 1961, p. 59).

- "The role of the vice principal, or assistant principal, in the American secondary school is still a clouded issue today" (Hurley, 1965, p. 12).

- "One of the challenges confronting secondary school educators today is the development of a role definition for the assistant principal, both by title and job delineation" (Childress, cited in NASSP News letter, 1973, p. 1).

- "The problem [defining the assistant principalship] is perhaps due in part to the limited attention that has been given to the study of this significant administrative role in education" (Kriekard \& Norton, 1980, p. 1). 
Duties Performed by Assistant Principals

The second general area of the literature on the assistant principalship centers around the various duties performed. Hentges (1976) conducted a study in Minnesota modeled after the NASSP's normative study (Austin \& Brown, 1970). His conclusions paralleled those of the NASSP work in the following ways:

- Assistant principals were involved in nearly all administrative processes (p. 88 ).

- Assistant principals were not often allowed "total" responsibility for a task (p. 88).

- The assignments given assistant principals were not perceived as requiring a high degree of decision-making authority; the only exceptions were discipline,attendance, detention--al1 pupil personnel functions (p. 89).

- Although there were some reported differences in work by type or location of school, variances were based on degree of involvement only ( $p .93)$.

- More principals than vice-principals thought that the assistant principal had responsibility for significant duties requiring high levels of authority in decision-making (p. 92).

- The "core" of assistant principal activities seemed to include curriculum and instruction tasks, staff personnel activities and pupil personnel responsiblities (Table 4.14, p. 79). 
Other writers over the last half century have addressed the spectrum of assistant principal tasks (Hencley, 1963; Long, 1957; Novak, 1963; Rankin, 1973; Van Eman, 1926). The work of Austin \& Brown (1970) exemplifies the descriptive approach. A prescriptive tack was taken by Hencley when he suggested interrelationships in policy making and technical administrative duties for school leaders, from superintendents to coordinators. Tasks designated to the assistant principal's direct attention and supervision would be as follows (Table III, pp. 74-81):

- Instruction and curriculum development (relating curriculum to time, facilities, personnel)

- Staff personnel (orientation and scheduling of professional staff, securing and scheduling substitute teachers)

- Pupil personnel (student orientation, scheduling, counseling services, student records, occupational and educational information services, assessment and interpretation of student growth, dealing with pupil irregularities, activity programs, attendance)

- Finance and business management (inventory of equipment and upplies)

- School/community relations (reports and bulletins to the community, conferences with parents and citizens, releases to the media, improvement of student progress reporting, development and coordination of the overall school/community relations program)

Related articles also focus on what might be considered the primary assistant principal duties. The theme is often the preeminence of pupit personnel functions. Fallon (1974) stated: "As assistant principal, 
there are two areas of prime responsiblity that will either make or break an administrator. These are attendance and school discipline" (p. 77). Of the ten articles comprising the October, 1973 edition of the NASSP Bulletin, the only research-based article devoted to the assistant principalship was authored by Brown and Rentschler (1973). When determining the five duties most frequently assigned to Indiana assistant principals, Brown and Rentschler found, as Austin \& Brown (1970) had concluded earlier, that pupil personnel activities are usually a prime focus for the assistant principal. Burgess (1976) identified the duties most frequently mentioned by assistant principals as teacher evaluation, curriculum development and staff leadership, discipline, attendance, and student activities--the latter three, of course, being student personnel functions. Jarrett's (1958) survey in Los Angeles and in 23 of the 25 other largest cities in the United States determined that assistant principals were most involved in professional and inservice training, co-curricular activities, and pupil personnel services. Respondents, estimated that pupil personnel activities consumed 45 percent of their worktime, the largest allocation of time for a single set of tasks.

As a result of the identification of the assistant principal with pupil personnel activities, the literature includes contributions on these specific aspects of the assistant principalship. To iliustrate, Boettcher (1973) wrote on due process concerns regarding student discipline; Stokes (1973) on student activities. Greenham (1972) suggested an attitude the assistant principal might take regarding discipline: "It would appear that most assistant principals are seen as disciplinarians--a necessary but thankless job. It is necessary, but must it be 
thankless?" (p. 27); "The point I'm driving at is that the disciplinarian role for anyone--principal, assistant principal, teacher, parent--can be a teaching role and a learning role... It will depend on our viewpoints and our interpersonal relationships" (p. 28). Collins (1980) and Mitchell (1976) presented similar viewpoints, stressing the creation of humane environments for students.

The composite of literature on assistant principal duties, presents two divergent viewpoints. Gillespie (1961) stated, "The scope of duties... of the assistant principal has changed from a narrow range of clerical and routine activities to a broad range of administrative and supervisory functions" (p. 56). And the fact that Burgess (1973) emphasized the curricular functions of the vice-principal and Turner (1973), the related topic of instruction, might lend support to such a claim. Conversely, as recently as 1972, Greenham contended, "I am concerned, however, that the position of assistant principal often is too heavily weighted in the direction of 'para-professional' tasks" (p. 29).

\section{The Assistant Principal's Job Satisfaction}

The third significant topic in the literature on the assistant principal--job satisfaction--is related to the previous subject of duties. The 1970 NASSP Career Study (Austin \& Brown) determined that a low level of job satisfaction, relative to that experienced in other positions, plagued assistant principals (p. 72). Croft and Morton (1972) found that 41.7 percent of Houston assistant principals and 60 percent of Kansas assistant principals found satisfaction with their positions; only 14.7 percent and 25 percent, respectively, planned to remain assistant principals. The investigators delineated the tasks associated with 
satisfaction: orientation (for students and teachers), selection and evaluation of teachers, varsity athletics, public relations, and curriculum development. Dissatisfaction stemmed from the more routine and clerical tasks--building use, student photos, transportation, and testing. Black's (1980) Maryland survey revealed that for 66 percent of the respondents the best-liked jobs areas were related to the instructional program; discipline-related tasks were least liked by 83 percent. A similar study, involving 164 assistant principals in southeastern Pennsylvania (Garawski, 1978), had "determined that the tasks of teacher evaluation, teacher supervision, and preparation of the school master schedule generated the highest degree of job satisfaction, and that there was a strong positive correlation between satisfaction and the parameters of task responsibility, task importance, and discretionary authority" (p. 9). Respondents' comments indicated that job dissatisfaction arose from long work hours, a lack of assistance and attention from superiors, teachers' negative perceptions of their handling of student discipline problems, students' perceptions of them as solely disciplinarians, the constraints of federal and state policies and court decisions relative to due process and discipline, and having their contributions attributed to superiors. Self-image appears to be a possible link between assigned duties and resulting job satisfaction. Bordinger (1973) addressed the question of negative self-image of assistant principals. Burgess (1976) contended that assistant principals sometimes view themselves as "bad guys" ( $p$. 79). She had stated in 1972, "It [the assistant principalship] is a developing role that is presently filled with deep frustrations" (p. 77). 
Hopes for advancing the assistant principal from mere disciplinarian to educational leader and, thus lessening dissatisfaction in the position pervade the literature to date (Clements, 1980; Potter, 1980). The stereotype and the resulting plea is the same throughout. Greenham (1972) described the assistant principal as a "buffer for the executive" (p. 28), Mazzei (1976), as a "part-time record keeper" (p. 319); Bordinger (1973) labeled the stereotypical assistant principal as a "rent-a-cop" (p. 13). "Hatchet man" is the term used by several (Bevan, Bugher, Mazzei, Moore, and Nichols, 1973, p. 88; Greenham, 1978, p. 28; Hurley, 1965, p. 12; Mazzei, 1976, p. 319). Culver's (1978) following statements reflect the view of many of the writers previously cited:

There is an injustice being committed in school administration, and unless some determined steps are taken to correct it, a vital member of the administrative team will be rendered virtually ineffective. The problem is the stereotyping of the assistant principal as an enforcer whose only responsibility is to chase smokers, dopers, and truants. (p. 112)

It is this writer's firm belief that any person in education, whether a teacher or an administrator, is first and foremost an educator. (p. 113)

Three ways to ameliorate the situation are usually suggested: change assignments, use team management, and integraliy involved with both--modify relations between principal and assistant principal. Novak (1963) expressed the concern felt by many about relations between principal and assistant:

It is necessary for the principal and the vice principal to be able to operate comfortably within a mutually acceptable point of view that allows each his individuality and free expression of opinion, yet permits a reasonably united front. A vice principal who performs minor errands without latitude or authority to make any decision on his own is not justifying his salary, loses self-respect, the position itself suffers, and he may lack assurance and creativity if he ever should emerge from the shadow of the principal. (p. 20) 
This concern loomed greater when the 1970 NASSP study (Austin \& Brown) revealed that principals and their assistants had differing views of the importance and authority of the assistant principalship (p. 47). Bevan et a1.(1973) pointed out that the principal determines not only what an assistant principal will do but also how much authority will be granted to the position. Brown and Rentschler (1973), in attempting to discover why the assistant principal is not always promoted to a vacant principalship, contended that the principal may well bear some responsibility for the assistant principal's lack of preparation, by hindering professional growth through narrow duty assignments. The authors inquired, "To prepare to become a brain surgeon, does a medical intern limit himself to appendectomies?" ( $p .43$ ). The editor of the NASSP Bulletin (1973) stated quite strongly, "If there is a dominant message to be heard from the several authors in this Bulletin, it is that the role of the assistant principal in any given school is exactly what the principal in that school wants it to be" (p. 124). Crowson and Porter-Gehrie's (1979) statement is equally direct: "Principals (both high school and elementary) delegate very little responsibility to their subordinates" (p. 26). And yet, Salley, McPherson, and Baer (1979) determined that school characteristics accounted for the greatest variations in a principal's work. Of particular relevance to an examination of the assistant principalship would be the finding that the school variable of "administrative levels down" affects the extent to which a principal's job involves such task areas as problems in student adjustment, dealing with gangs, safety regulation, utilization of specialized staff, and individualized student development. 
Suggestions for modifying the assistant principal's job, and thus increasing job satisfaction, abound. Burgess (1972) suggested that principals should provide their assistants with satisfying job experiences beyond attendance and discipline, scheduling, and food service. Hurley (1965) recommended increased assistant principal involvement with such responsibilities as curriculum and instruction and public relations. Mazzei (1976) promoted the idea of evaluation--of both teachers and programs--as a legitimate area for attention from assistant principals. When New York vice principals were asked about time devoted to various duties, "They stated that approximately one-fourth more time should be given to public relations, one-tenth to pupil personnel, three-tenths to curriculum, four-tenths to professional growth, but almost 50 percent less time should be ceded to attendance and to tests and records" (Long, 1957, p. 32).

Perhaps, the administrative dilemma of allowing the principal to delegate duties to the assistant principal as seen fit and yet providing the assistant principal with broad administrative experiences is illustrated by two apparently conflicting comments by a single writer. Jarrett (1958) maintained, "Greater participation by the assistant principal is needed in the supervision of departments, and in the overa11 supervision of instruction, as directed by the principal" (p. 31); yet, a recommendation in the same article stated, "The principal should exercise a free hand in assigning specific administrative duties to assistant principals" (p. 31). The first comment gives a specific direction for the principal; the latter gives free rein. 
Egan's study of the relations between principal and assistant principal (1969) also exposed the dilemma in the following propositions:

Proposition 2. The relationship of superordinate and subordinate tends to become dysfunctional, insofar as organizational goal achievement is concerned, as the subordinate becomes overly compliant to the demands or orders of his superior. (pp. 85-86)

Proposition 4. Although the superior is by definition the dominant member of the superordinate/subordinate dyad, the functioning of the organization is impeded unless that domination and authority is accepted by the subordinate. (p. 88)

Proposition 5. An important function of the superordinate in the allotment of organizational tasks is the balancing of institutional demands with the personal needs of the subordinate. (p. 89)

Typically, the assistant principal is involved in many administative activities but has little sophisticated decision-making responsibility. Austin and Brown (1970), echoed by Bordinger (1973), suggested shared decision-making as a solution. Others (Bordinger, 1973; Burgess, 1973; Childress, 1973; Gross et al, 1980; Joly, 1973; Rankin, 1973; Sprague, 1973; Valentine, 1980) supported a team-management approach to school administration. Burgess (1976) was optimistic on this point: "The professionalism and realism of most assistant principals and the corresponding concern of many principals afford high hopes that an effective administration team is possible in many secondary schools" (p. 77).

\section{The Assistant Principals' Career Plans}

Career planning is the fourth major topic in the literature on the assistant principal. The basic question--is the assistant principaiship a career position or preparation for further advancement?--remains unanswered. Barratt (1955) contended that one reason to employ an assistant principal is, "To act as a training opportunity for future principals, thus tending to insure continuous professional leadership for the educational program of the school" (p. 56). Jarrett (1958) concluded from 
his study of city assistant principals that, "The assistant principalship is the proper internship for the position of principal of a secondary school" (p. 31). On the other hand, more and more view the assistant principalship as a career goal in itself. Greenham (1972) said, "I am inclined to believe that we should view the Assistant Principal's position as having stronger career possibilities" (p. 32). A year later, Bordinger (1973) spoke to establishing the assistant principalship as a career position. Burgess (1976) remarked:

It should be noted that there are now a substantial number of assistant principals who see the position as a career goal in itself. With an increased number of assistant principals, particularly in large school systems, and with declining enrollment, it is obvious that many assistant principals will never become principals. There are, however, some assistant principals who genuinely like their jobs. (p. 78)

Brown and Rentschler (1973) provided some further documentation for this trend. One reason why assistant principals do not necessarily move to principalships is that they elect to remain in the viceprincipalship.

The Workdays of Assistant Principals

The foregoing representation of the literature on the assistant principalship evidences great concern on the part of students and practitioners of educational administration. However, there are relatively few contributions on the subject, and many of those appear in a single journal--the NASSP Bulletin. The Bulletin is not research oriented and focuses on the role of the assistant principal only occasionally, as it did in 1973 and in 1980. The topics related to the assistant principalship are many; often many topics are covered in a single short article. Recent contributions do not go beyond the major NASSP study 
in 1970, due largely to the lack of research replication and expansion. Certainly, there is no integrated view of the assistant principal's workday.

There is, however, some interest in the underlying nature of the assistant principals day-to-day managerial work. As early as 1957 , Hurwitz entitled a short article "A Day in the Life of an Administrative Assistant," outlining the day chronologically from building patrols, student counseling, parent conferences, to the design of an organizational flowchart. Bordinger (1973) spoke to the crisis- and peopleorientation of the position: "Many administrators classify the job as a crisis-orientated position most frequently dealing with people who are experiencing some degree of distress or disaster" (p. 10). He also referred to the nature of the work: "Of the many concerns assistant principals have regarding their position, none seems to concern them more than the workload or time involved in discharging their responsibilities" (p. 11). Childress contended (1973) that one of the emphases of preparation for the assistant principaiship should be an understanding of the actual administrative activities. Brown and Rentschler (1973) suggested that practicing assistant principals could profit from analyzing a selfrecorded activity $10 \mathrm{~g}$. Bevan et al. (1973) did exactly that on a rather casual basis, and from their logs, concluded:

- "He [the assistant principal] will participate in hundreds of minute managerial tasks" (p. 81).

- "Much of his week is spent in listening to people" (p. 82).

- "One thing is certain. He will not have to worry about finding something to keep him busy" (p. 83). 
Summary

This chapter recounted the contributions and conclusions of researchers, in business, industry, and education, on the nature of everyday managerial work. Mintzberg's (1973) observation methodology and study conclusions regarding managerial work provided the basis for this investigation; therefore, the work of other managerial work researchers was compared to and contrasted with Mintzberg's. In addition, the literature on formal organizations was explored for its relevance to managerial work research. Together, the writings of managerial work researchers and formal organization theorists provided the context for this investigation of a particular manager in a particular formal organization: the assistant principal in an urban school system.

The present educational administration literature on the assistant principal was found to be disappointing in several ways. The articles and books on the subject are few in number; for the most part, hortative in nature; and inconclusive on major topics, such as role, duties, and career status. A coherent description of the assistant principal's work is not available to researchers or to those in the position or aspiring to it.

The review of relevant literature confimed that further exploration of the assistant principal's role, duties, job satisfaction, and career aspirations was necessary. The structured interviews used by the investigator provided this needed study element. The major contribution of this study, however, is an integrated account of the assistant principal's actual work day, derived from direct observation. A gap in the educational administration literature is, thus, filled. Also, because 
the Mintzberg framework for structured-observation (1973) is employed, the results of this study can be synthesized with studies which employed a similar framework but were directed at other school executives (Crowson and Porter-Gehrie, 1980; Peterson, 1978; Pitner, 1978). This study's specific research questions centered on six topics which, from an analysis of the reviewed literature, emerged as focal study topics: workday activities, duration, pace, interactions, initiation/reaction, and workday differences. The following chapter considers these research questions and outlines in detail the framework for data collection, particularly the structured-observation process. 
CHAPTER III

METHODS AND PROCEDURES

\section{Introduction}

The preceding chapier ended with the premise that an observational study of the assistant principal's workday was necessary due to the various inadequacies in the literature on the assistant principalship. Specifically, this literature is scanty, fragmentary, and problemoriented. When a body of literature on a managerial position is so small and piecemeal, a priority emphasis should then be laying appropriate ground work--an integrated account of the manager's day-to-day work, based on research data rather than practitioner opinion. In this way, fragmentation is addressed, since the focus is a broad one--the underlying nature of the assistant principal's workday, rather than a look at bits and pieces of that work. Further, the problems related to the assistant principalship can be more responsibly addressed in the future if an accurate description of the assistant principal's work is available.

The six research sub-problems delineated previously were developed so as to provide the needed integrated view of the workday of the assistant principal. The first five are directed toward specific aspects of daily managerial work: activities, duration of workday, pace, contacts, and degree of work initiation-reaction. The final subproblem inquires 
about possible differences in the workdays of various assistant principals. In combination, the research subproblems established the framework for a directed inquiry regarding the content and nature of the assistant principal's everyday work. The resulting challenge was to design a study congruent with these research problems.

The remainder of this chapter is devoted to the study's methodology and procedures. The immediately following section is a review of selected 1iterature relevant to field study methodology. In succeeding sections, study sampling and data-collection procedures are described. Finally, the procedural problems encountered in this investigation are discussed.

\section{Review of Literature}

Within the last decade, both the literature of management and of education have contained clear statements of the value of observational studies. For example, Davis and Luthans (1980) attributed the discrepancies between the traditional management literature contentions and the reality of managerial work to the use of the traditional methods. A similar refrain is echoed in education circles. Sarason (1971) argued for the need for more accurate portrayals of the schools, as "There is a growing awareness that we know far less about the 'active functioning of schools and school systems' than we have realized" (pp. 229-230). Wolcott's (1971a) comments are more particularly directed at the need for observational data regarding the educational manager, since the nomative literature provides "virtually no insight into what it is like to be one of these people" (p. 347). 
In sum, various contributions to the literature of management, of education in general, and educational administration in particular, reveaied a need for fresh observation and description rather than unquestioning reliance on past literature precepts and theories. What appears to be necessary is movement toward what Glaser and Strauss (1967) have termed "grounded theory": social research that generates data from which theory-building might emerge, en lieu of data collection intended to simply validate past theory. Weick (1968) further specified the direction for an investigator choosing to contribute meaningful data by stating, "The fallibilities of retrospective data are reason enough for an investigator to attempt an observational study" (p. 364). The major point reiterated by the foregoing writers is, simply stated: in order to insure that further literature in management and in education is congruent with reality, one must observe behavior in its natural setting. Then, from observational/descriptive research, theory can more appropriately emerge.

In order to pursue an observational study, one can turn to the socio-anthropological field study literature where many of the standards for responsible observation have been set. Rather central to this literature is the ethnographic method, originally emerging from anthropology but more and more being applied in education settings. Wolcott (nd) stated, "Although the term 'ethnographic research' has gained recent currency in education, it is often used inappropriately" (p. F3). Inherent to ethnography is what Rist (1980) labeled "the traditional 'rite of passage' a prolonged field study" (p. 9). Nomally, this training 
experience is crosscultural (Wolcott, nd; Rist, 1980). When in this setting, the entire cultural milieu can be studied. Of course, focusing one's observation on the schools and the school day is a distinct restriction of the ethnographic approach and has been noted by Rist and Wolcott. Wolcott (1975) stated, "The commitment to education as a cultural process necessitates a broader perspective than that obtained by confining one's attention to events within the walls of the school building" (p. 113). Rist (1980) said, "The traditional assumption was that a single individual... would go to. the field site, become enmeshed in the life, and only after a long and involved period of time, begin to formulate a framework for the analysis" (p. 9). Wolcott, specified additional standards for data collection and reporting. He (Note 2) referred to description rather than judgment, as a "canon" of ethnography (p. 3). Such description, he (1974b) contended, results from "the ethnographer's multi-instrument approach" (p. 178). Describing the reporting of data as necessarily rich in detail Wolcott (1975) said, "I would insist that any ethnographic account should contain a wealth of primary data: actual quotes from informants, related in their own words from comments and written documents" (p. 124). Though educational ethnography has often defied various aspects of the preceding model, it also appears that borrowing from this anthropological method can result in valuable educational studies: "Educational research can benefit from the characteristics of ethnography... without claiming to be ethnography" (Wolcott, nd, p. F4). 
Perhaps the greatest benefits derived from the literature on field study are (1) the resolution of criticisms frequently leveled at qualitative studies and (2) comprehensive examples of the field study methodology as applied to education. The major drawbacks of field work are often considered to center on scientific purpose, sample size, and the effect of the observer's presence. Though some researchers from the quantitative school of thought contend that the purpose of research is hypothesis-testing, Lutz and Iannaconne (1969) maintained, as did Glaser and Strauss (1967), that research can and should be hypothesis-building/ theory-building as wel1. In fact, Lutz and Iannaccone have stated quite strongly, "Prejudgment in terms of hypotheses are not necessary or desirable as the process is studied" (p. 115).

Both Cusick (1975) and Wolcott have spoken to the question of limited and selected sample. Cusick addressed the topic directly when he said, "Since the subjects are usually limited in number and selected by chance, the resulting data, while interesting, is not transferrable to other situations. On a superficial level this might appear true. However, those of us who understand such studies feel that men are more alike than they are different" (p. 5). Wolcott (nd) also emphasized the Tatter thought when he described ethnographic research in this manner: "Ethnographic research seeks understanding of the particular as an example of the severa1. Classes of events are better understood through a more thorough examination of a particular case" (p. F5).

Another charge directed at field researchers is that because they intrude upon a natural environment, their presence must affect the very behavior they intend to observe and describe. Closely related to this 
concern is the complicated issue of observer role. Lutz and Iannaccone (1969) stated, "Rather than claiming that the observer's presence does not modify the behavior at all, it is more reasonable to expect that the essential elements of the social system under investigation will not be modified if the role of the observer is carefulty chosen and planned" (p. 107). The authors went on to provide the following description of the roles available to an investigator wishing to describe behavior in a social system:

1. The participant acting as scientific observer (owning group membership)

2. The observer as limited participant (allowed group membership)

3. The observer as a non-participant (wi thout group membership)

4. The observer (without presence in the group) (p. 121)

Three studies of behavior within educational organizations are: Inside High School: The Student's World (Cusick, 1973), Boys in White: Student Culture in Medical School (Becker, Geer, Hughes, and Strauss, 1961), and Anatomy of an Educational Innovation: An Organizational Analysis of an Elementary School (Smith and Keith, 1971). In the first project, Cusick set out to describe high school life from the student's view. He attended classes, ate in the student cafeteria, and participated in after-school social life. His work resulted in descriptions of various aspects of student life, such as the schoolday, classroom interactions, and student cliques. The medical school work produced descriptive accounts of the various perspectives medical students develop over time, for example, the "Best of All Professions" stance (Chap. 5) and the "Learn it A17" attitude (Chap. 7). In the third study, Smith and Keith observed the evolution of an innovative elementary school and developed 
description on such aspects of schooling as the faculty and pupil social systems and teacher innovation and instruction.

The observations of all three of these studies were conducted in a participant observer role. And yet, Wolcott (1974) purported:

It is very difficult to be an effective participant/ observer in a school unless one selects among the limited number of statuses available for effective participation.... and his own experience with the institution may preclude his being a keen observer in a setting where most everything is already familiar. (p. 1)

Furthermore, an advantage of the role of nonparticipant is that, "The observer as a nonparticipant can take notes while observing without affecting or altering behavior" (Lutz and Iannaconne, 1969, p. 121).

A final consideration for field study work is whether observation data-collection should be structured or unstructured. As previousiy mentioned, ethnography assumes no formulation of framework for recording and analyzing data (Rist, 1980; Wolcott, 1975). However, even an ethnographer such as Wolcott (1975) has begun to reconsider this stance: "I am coming more and more to recognize the necessity of some degree of problem orientation" (p. 114). On the other extreme, Lutz and Iannaconne (1969) have stated, "Of utmost importance to the data collection is a previously chosen model. This will serve as a guide for data collection" (p. 128). Mintzberg (1970) defended structured observation as, "A methodology which couples the flexibility of open-ended observation with the discipline of seeking certain types of structured data" (pp. 89-90).

\section{General Methodological Perspectives}

This study would be classified under the general rubric of a field study, one that borrows from the more restricted field of 
ethnography. A smal1, selected sample was directly observed in the natural environment, with the researcher assuming the nonparticipant observor role. Though a structured framework for data collection was employed, hypotheses were not developed to guide the study; and description, not judgment, was the major research intent. In order to amass the richest possible description, a multi-instrument data-collection approach was designed.

\section{Sampling}

The site for this study was an urban school district on the West coast. From this district, five high school assistant principals were selected for study participation. Criteria for selection were that the person had served as an assistant principal at the same building site for at least two years and that the composite sample represent a crosssection of major administrative functions performed by assistant principals, such as activities/athletics, curriculum and instruction, and student discipline. These criteria were developed to ensure that neither lack of experience in position or building nor emphasis on a single type of job description would bias conclusions regarding the workday of an assistant principal. When it was determined that more than five district assistant principals met the two criteria, representativeness of socioeconomic status of school community, sex and ethnicity of assistant principals were additionally considered in selecting the five study participants.

Certainly, this is not a randomly chosen sample. However, the care exercised in selection would be comparable to that of the Austin 
and Brown shadow study (1970). The factors used as considerations for sample composition (difference in regions of the country, size and grade ranges of student body, financial resources of the school, and community character [p. 14]) differed; however, the general approach of simply seeking adequate variety was precisely the same.

The investigator telephoned each selected assistant principal to briefly explain the study purpose and to request participation; all promptly agreed to participate. Before observations began, a conference to provide information and answer questions was held with each assistant principal, as Wolcott (1971b) contended, "Explicit statements of mutual expectations might alleviate misunderstanding or at least lead to more precise delimitations of rights and duties" (p. 107). At this time, the study intent--description of the workday, rather than judgments regarding it--was emphasized. Data collection procedures were enumerated and explained briefly. Additionally, anonymity in the written report was emphasized as a researcher obligation; protocol for securing conference observation permission from parents, students, and teachers was discussed. During this initial meeting, an observation schedule was also developed. Pitner (1980) commented that her selected superintendents indicated some desire to choose days for observation based on their calendars (p. 69). In order to alleviate the possibility of assistant principals proposing specific kinds of workdays, the investigator instead proposed a set schedule of days. In no instance was this schedule modified by participants. Finally, each subject assistant principal signed an "informed consent" form in which confidentiality was again stressed; risks to participants were stated as "invasion of privacy, inconvenience, demand on my time." 
Data Collection, Coding, and Analysis

Each of the five assistant principals was directly observed through the five days of the week. Because of the investigator's own work obligations, a single complete observation schedule normally required a three-week period; however, this was actually advantageous, as observations were extended over a longer period of time and were not concentrated in a single week that might have been unique in some way. If early morning or evening events were part of an assistant principal's scheduled observation day, the investigator was present to observe and record those activities as well. Written as a first-person scenario, the assistant principal might describe the shadowing experience in the following way: "I was followed throughout five days of my day and evening work: desk work, telephone cal1s, meetings, tours and encounters."

The investigator employed the ethnographer's multi-instrument approach whereby primary data could be reviewed and description, rather than judgment, could be the focus. Data-gathering techniques included the following:

- Field notes regarding the assistant principal's physical environment and the high school's administrative procedures and structure - Structured observations of the workday recorded and coded on the Chronology, Communication, and Contact Records developed by Mintzberg (1973)

- Reviews of correspondence and documents, as needed to make field notes, to aid in the structured-observation process, and to provide background on each assistant principal 
- Structured interviews, in order to elicit further information regarding the assistant principal's workday and to determine the degree to which subject assistant principals' views of their position were comparable to sentiments expressed in the literature

Data were collected while the investigator was in the nonparticipant observer role. In fact, in a conversation with Wolcott (Note 3), the investigator inquired whether, in this study, the observer role would be characterized as nonparticipant. Wolcott replied, "Classically, probably. Be whatever they will let you be. You can be too sterile. They want a little sympathy...the one mistake I made probably with my study....Talking for them is a catharsis." As a result of this advice, the investigator attempted to affect the workday as little as possible, but yet tried to also recognize the importance of being an interactive, nonthreatening human being.

The selected framework for structured observation, essentially that of Mintzberg (1973), requires explanation. The activities of the assistant principal's workdays were recorded on three records--the Chronology Record, the Communication Record, and the Contact Record (Appendix A). The Chronology Record consisted of three entries documenting the sequence and duration of daily activities. Activity media were recorded as desk work, telephone call, scheduled or unscheduled meeting, or tour. Desk work consisted of the processing of mail and other paperwork, at times with the assistant principal's secretary. Telephone calls (including those on in-house telephone or intercom systems) were recorded if completed (i.e., at least a message was left). Although the assistant principals' incomplete telephone calls often 
resulted in frustration and the postponement of normal follow-up work, the telephoning attempts hindered by busy lines and no answers were not recorded. An unscheduled meeting was one that was arranged hastily, often when a contact entered the assistant principal's office, while a scheduled meeting was one planned in advance. Tours were of two kinds: informational tours to deliver or to gather information and observational tours to observe school-related operations and events, in and outside of the building and el sewhere in the city. Next to each activity medium listing, the starting and ending times and durations of activities were recorded. ATso, activities were cross-referenced to the two other records--a letter indicating a Communication Record reference and a number, a reference to the Contact Record.

The Communication Record was used to document an observation day's incoming and outgoing mail, internal or external to building and district. For each piece of mail, form, sender, purpose (and receiver if outgoing), attention given, and action taken that day were specified. To illustrate, a communication might be recorded in the following manner: memorandum (form), building principal (sender), telling of open house plans (purpose), skimmed (attention), filed (action). The Contact Record chronicled for each meeting, telephone call, or tour purpose, participants, number of participants, initiation, duration, and place. Initiation of contact could be designated as self (the assistant principal), contact (another person or event), mutual (by mutual, often unspoken, agreement between the assistant principal and a contact) or clock (a regularly-scheduled activity). 
In the following section, approximately one hour of an assistant principal's morning is described and the records developed from it presented (Tables I-III) in order to illustrate the structured-observation procedures.

$8: 00-8: 01$

When the AP enters the office, a mother tells him that her son is returning the next day and wi11 be there for the "staffing" meeting.

$8: 03-8: 27$

The AP tours the halls as the school day begins. He volunteers to carry a box of materials to the Career Center for a volunteer nurse. The Administrative Assistant and he discuss an administrative transfer and a student. One of the students asks about the student fire squad of which he is a member. The AP is approached by a secretary who tells him (1 minute) that students have been observed outside, allegedly selling drugs. He's told that the "baggie" is now in one of the student's socks. The Administrative Assistant and he go outside and bring the four suspected students back to the office. (In addition to the contacts specified above, the AP spoke briefly to nine teachers, two counselors, a secretary, an aide, and a student.)

\section{$8: 27-8: 31$}

The Administrative Assistant and the AP tell the four boys that there are two ways the situation can be handled. The police can be called, or the students can submit to a voluntary search. The students choose the latter, and no drugs are found. Three students are dismissed. 
The fourth is told of a referral that states he was seen spitting on an Asian student. The student is asked if he understands the definition of assault.

(Exact time not known, but 1 minute or less duration)

The AP starts out on an observational tour; but as he leaves his office, the secretary tells him that a mother and son are waiting to see nim.

\section{$\underline{8: 33-8: 55}$}

Mother and son, AP, and eventualiy a counselor assigned to the student (called at 8:50 and asked to join the meeting) discuss the young man's attendance problem, his schedule, and his desire to work at a local department store. The AP stresses that at least sixth-grade reading level is necessary in adult life and calls (8:36-8:38) the Title I secretary to find out the student's reading level (he is told it is 5.8 grade). The student is told that since he's not yet 16 , the store would likely not hire him during the school day. The AP calls the store (8:48-8:49) to determine its policy on working hours for teenagers (he is told that it is probably 3:00-5:00; that he' 11 be called back later with a final answer). The mother says that getting her son to attend school is a "hopeless case." The AP suggests involving the woman on special assignment for students of Native-American ancestry. Results of the conference are:

1. The student can drop algebra and Teave at 1:30 for work.

2. If the student doesn't attend his other classes, the AP will call the store.

3. The case is turned over to the counselor's supervision. 
4. The mother will get a work permit for her son that afternoon. $\underline{8: 59}$

The AP asks his secretary to have someone come see him. 8:59-9:01

Back and forth between their two offices, the AP and Administrative Assistant talk about materials the Assistant is developing for a meeting regarding feeder students. The Administrative Assistant is given relevant information; the AP requests follow-up.

\section{$\underline{9: 01-9: 10}$}

The AP looks over some mai1: a neighborhood newspaper, the daily bulletin, and an attendance form telling of a runaway and of whom to contact if anything becomes known about this student. 
TABLE I

A CHRONOLOGY RECORD

\begin{tabular}{|c|c|c|c|c|}
\hline Start & End & Duration & $\begin{array}{l}\text { Unscheduled Meeting } \\
\text { Scheduled Meeting } \\
\text { Desk Work } \\
\text { Phone Call } \\
\text { Tours or Encounters }\end{array}$ & Reference \\
\hline $8: 00$ & $8: 01$ & 1 & Unscheduled meeting & 1 \\
\hline $8: 03$ & $8: 27$ & 24 & Observational tour (2) & 2,3 \\
\hline$-\infty-$ & $-\infty-\infty$ & (1) & Unscheduled meeting (3) & \\
\hline $8: 27$ & $8: 31$ & 4 & Unscheduled meeting & $4, A$ \\
\hline-- & $-\infty$ & 1 & Unscheduled meeting & 5 \\
\hline $8: 33$ & $8: 55$ & 22 & Unscheduled meeting & 6 \\
\hline $8: 36$ & $8: 38$ & 2 & Telephone & 7 \\
\hline $8: 40$ & I & 1 & Telephone & 8 \\
\hline $8: 48$ & $8: 49$ & 1 & Tel ephone & 9 \\
\hline $8: 59$ & / & 1 & Informational tour & 10 \\
\hline $8: 59$ & $9: 01$ & 2 & Unscheduled meeting & 11 \\
\hline $9: 01$ & $9: 10$ & 9 & Desk & $B-D$ \\
\hline
\end{tabular}


TABLE II

A WRITTEN COMMUNICATION RECORD

\begin{tabular}{|c|c|c|c|c|c|}
\hline Reference & Form & Sender & $\begin{array}{l}\text { Purpose } \\
\text { ( } \& \text { Receiver?) } \\
\text { as perceived by } \\
\text { Assistant P. }\end{array}$ & \begin{tabular}{ll}
\multicolumn{2}{c}{ Attention } \\
Glance & Study \\
Skim & Write \\
Read & Proof
\end{tabular} & $\begin{array}{l}\text { Action } \\
\text { File Note } \\
\text { FYI Sign } \\
\text { Forward Send } \\
\text { Confer Respond } \\
\text { Reply W/Basket } \\
\text { or combination } \\
\end{array}$ \\
\hline A & $\begin{array}{l}\text { student management } \\
\text { referral form }\end{array}$ & $\sec ^{\prime} y$ & $\begin{array}{l}\text { told of student } \\
\text { spitting on Asian }\end{array}$ & read & $\begin{array}{l}\text { confer with stu- } \\
\text { dent }\end{array}$ \\
\hline B & local newspaper & local press & periodical news & glance & $\begin{array}{l}\text { (nothing that day } \\
\text { though usually } \\
\text { reads; makes } \\
\text { available to } \\
\text { students) }\end{array}$ \\
\hline C & daily bulletin & school office & periodical news & skim & wastebasket \\
\hline D & attendance form & $\begin{array}{l}\text { school } \\
\text { attendance } \\
\text { office }\end{array}$ & $\begin{array}{l}\text { informed of runaway } \\
\text { and whom to con- } \\
\text { tact with info }\end{array}$ & read & $\begin{array}{l}\text { confer with sec- } \\
\text { retary (and } \\
\text { tried to tele- } \\
\text { phone) }\end{array}$ \\
\hline
\end{tabular}


TABLE III

A CONTACT RECOPD

\begin{tabular}{|c|c|c|c|c|c|c|c|}
\hline Rerarence & Med ius: & Purpose & Participant (s) & & $\begin{array}{l}\text { Initiation } \\
\text { Self } \\
\text { Contact } \\
\text { Mutual } \\
\text { Clock }\end{array}$ & $\frac{5}{0}$ & $\begin{array}{l}\text { 1. Slar.n } \\
\text { 2. A.Perior's of office } \\
\text { 3. Peer's office } \\
\text { 4. Subord.'s Office } \\
\text { 5. Hall/Piant/Ornunds } \\
\text { 6. Conf./Bd. Pr. } \\
\text { 7. Elsewh. /Dist. } \\
\text { 8. Cominuity } \\
\text { 9. Away/Drg. }\end{array}$ \\
\hline 1 & $\begin{array}{l}\text { unscheduled } \\
\text { meeting }\end{array}$ & $\begin{array}{l}\text { toid of student } \\
\text { returning/would } \\
\text { be at "staffing" } \\
\text { tomorrow }\end{array}$ & mother & 2 & contact & 1 & counseling center \\
\hline 2 & $\begin{array}{l}\text { observational } \\
\text { tour }\end{array}$ & $\begin{array}{l}\text { touring at begin- } \\
\text { ning of school }\end{array}$ & $\begin{array}{l}\text { teachers - } 9 \\
\text { nurse } \\
\text { Ad. Asst. } \\
\text { counselors - } 2 \\
\text { sec'y } \\
\text { students - } 2 \\
\text { aide }\end{array}$ & $18 \mathrm{~T}$ & self & 24 & $\begin{array}{l}\text { hall, career } \\
\text { center, grounds }\end{array}$ \\
\hline 3 & $\begin{array}{l}\text { unscheduled } \\
\text { meeting }\end{array}$ & $\begin{array}{l}\text { told of students } \\
\text { outside with } \\
\text { "baggie" in sock }\end{array}$ & $\sec ^{\prime} y$ & 2 & contact & (1) & hall \\
\hline 4 & $\begin{array}{l}\text { unscheduled } \\
\text { meeting }\end{array}$ & $\begin{array}{l}\text { telling police } \\
\text { or voluntary } \\
\text { search/telling } \\
\text { student of spit- } \\
\text { ting referral and } \\
\text { assault defin. }\end{array}$ & $\begin{array}{l}\text { students - } 4 \\
\text { Ad. Asst. }\end{array}$ & 6 & self & 4 & AP office \\
\hline 5 & $\begin{array}{l}\text { unscheduled } \\
\text { meeting (on way } \\
\text { to observ. } \\
\text { tour) }\end{array}$ & $\begin{array}{l}\text { told mother and } \\
\text { son here }\end{array}$ & $\sec ^{\prime} y$ & 2 & contact & 1 & counseling center \\
\hline 6 & $\begin{array}{l}\text { unscheduled } \\
\text { meet.ing }\end{array}$ & $\begin{array}{l}\text { exchange and } \\
\text { negotiation re: } \\
\text { student atten- } \\
\text { dance, schedule, } \\
\text { work plans }\end{array}$ & $\begin{array}{l}\text { student } \\
\text { counselor } \\
\text { mother }\end{array}$ & 4 & contact & 1 & AP office \\
\hline 7 & telephone call & $\begin{array}{l}\text { asking reading } \\
\text { level of student } \\
(5.8)\end{array}$ & Title I $\sec ^{\prime} y$ & 2 & seif & 2 & AP office \\
\hline 8 & telephone call & $\begin{array}{l}\text { requesting coun- } \\
\text { selor to join } \\
\text { mtg. }\end{array}$ & counselor & 2 & self & 1 & AP office \\
\hline 9 & telephone call & $\begin{array}{l}\text { asking hiring } \\
\text { policy }\end{array}$ & $\begin{array}{l}\text { depart. store } \\
\text { employee }\end{array}$ & 2 & self & 1 & AP office \\
\hline 10 & $\begin{array}{l}\text { informational } \\
\text { tour }\end{array}$ & $\begin{array}{l}\text { asking } \sec ^{\prime} y \text { to } \\
\text { send someone }\end{array}$ & $\sec ^{1} y$ & $2 T$. & self & 1 & $\begin{array}{l}\text { counseling } \\
\text { center }\end{array}$ \\
\hline 11 & $\begin{array}{l}\text { unscheduled } \\
\text { meeting }\end{array}$ & $\begin{array}{l}\text { giving requested } \\
\text { info/requesting } \\
\text { follow-up re: } \\
\text { feeder proyram }\end{array}$ & Ad. Asst. & 2 & mutual & 2 & $\begin{array}{l}\text { Ad. Asst. office, } \\
\text { AP office. }\end{array}$ \\
\hline
\end{tabular}


After observation and recording such as that preceding, the Communication and Chronology Records were then coded for congruence with Mintzberg's (1973) categories. For example, mail form could be coded with letter or memo, and so forth; mail sender/receiver or contact participant could be specified in categories, such as subordinate, government, or peer. Finally, the categories of all three records were enumerated, calculated as percentages, and reported in tables which either summarized al1 data for assistant principal's or the composite sample's record, or focused on a more restricted aspect of the various records.

\section{Problems Encountered by The Investigator}

This section describes some of the major difficulties encountered in conducting this observational study. First, recording and coding problems relative to the Mintzberg (1973) framework are explained. Second, challenges to maintaining the nonparticipant observer role are recounted.

Pitner (1978) specified problems that she had in employing the Mintzberg framework, including what appeared to be an ambiguous demarcation between managerial and non-managerial work (pp. 70-74) and confusion regarding purpose categorizations ( $p p .74-78$ ). In this investigation numerous activities were considered to be non-managerial in nature and, as such, were not recorded on the three structured-observation records, except as brief paranthetical notes. The following are examples of excluded occasions: 
- Private telephone calls, on personal business and family matters

- Smoking and/or coffee breaks

- Lunch, when business was not conducted formally

- Personal tasks and errands, such as shopping, banking, or having blood pressure checked

The questions raised by Pitner (1978) regarding Mintzberg's (1973) purpose classifications--the blurring of distinctions between purpose and role and the confusion of purpose and function--were determined to be valid questions. Therefore, the investigator chose to approach recording of mail and contacts in the same manner as Pitner did. She stated, "Recorded in the purpose column...was a brief description of the content of the communication. Each communication was later analyzed as to purpose and notations made, but the original content was not obliterated with the purpose categorization" (p. 83). And for the Contact Record, she made a similar statement: "Again, instead of noting 'purpose,' a description of the content of interaction was noted" (p. 86). In this study the same procedure was employed. The content of a piece of mail or of contact was described on the records. Later, purpose designations were employed in the coding process.

It was necessary to expand Mintzberg's (1973) lists of communication and contact categories. This expansion was intended to meet one major goal: to employ categorizations appropriate to the assistant principal's level and type of job. Some categorizations additional to Mintzberg's were borrowed from Pitner (1978); others were developed for this specific investigation. In order to illustrate the nature of and rationale for these modifications, examples follow. 
- Note was added as a categorization for form of written communication on the assumption that the assistant principal would receive hastily composed handwritten messages from teachers.

- Peer A, B, C, Superior, and Subordinate A, B were additional categories for mail sender/target and contact participant. Mintzberg's work (1973) dealt solely with chief executives; therefore, a peer would be strictly external to the organization. However, an assistant principal has peers at three levels: within the building (A), in other buildings within the district (B), and external to the district (C). A7so, the chief executive has no organizational superior; the assistant principal in an urban district has many. Finally, the subordinates within the building and for whom the assistant principal had supervisory responsibility $(A)$ were distinguished from subordinates located elsewhere in the organization (B).

- Counseling/Discipline were added as contact purposes, since no Mintzberg (1973) category properly described the nature of the assistant principal's numerous conferences conducted for counseling and/or disciplinary purposes.

Even when the investigator was simply applying terms already used by Mintzberg (1973), problems arose. Such problems are listed and described in the following; in addition, the resolutions developed for this investigation are explained.

- Unscheduled Meeting - Mintzberg (1973) said, "Meetings are defined as unscheduled if they are arranged hastily, as when someone just 'drops in'" (p. 735). There is a place-orientation--the office-that seems to be implicit in that statement. Yet, the assistant 
principal is often sought out when on tour of the building. As a result, deliberateness, or intent, of contact was used to distinguish an unscheduled meeting in the hall from simply an encounter while touring.

- Tours - Since frequent tours were part of some assistant principal's daily repertoires, clarifications of that activity were needed. Mintzberg (1973) defined tours as, "a chance meeting in the hall, or...promenades taken by the manager to observe activity and to deliver information" ( $p .235)$. The investigator expanded the informational tour category to include instances when the assistant principal was seeking information as well as the times of information deliveries. Also, the evening work activities for assistant principals were often not meetings but were instead for the purpose of simply observing the progress of an event, such as a game or a community festival with which the school was involved. In such cases, the activity was deemed a form of observational tour.

- Mail - The assistant principal often reviewed pieces of mail that had been accruing on the desk for some time. Mail was recorded on the Communication Record only if it was received or initiated on an observation day. In this way a distortion of mail recording, whereby a single piece of mail could be inaccurately recorded more than once, was avoided.

- Participants - Two problems related to this category were: How many people, and which people are involved in a contact? At what point does a change in participants indicate a change in activity? On numerous occasions, the assistant principal's contacts took place in a group, even in a crowd. Only those people directly involved in a contact 
were recorded as participants, even though others might have overheard or observed the interaction. Second, participants moving in and out of a meeting were determined to have not changed that activity from its single, original designation. On the other hand, if participants markedly changed over time, a new activity--such as unscheduled meeting--was recorded with each clear change, even if the topic--such as a specific drug incident--remained the same.

- Initiation - It was a complex challenge to designate appropriately the nature of initiation, since an event or piece of mail could trigger numerous later interactions. Distinguishing original initiator from the initiator of succeeding activities was simply dealt with on a situation-specific basis, according to the investigator's best judgment.

- Target, Purpose, Participant, Place - As often as possible, a contact or a piece of correspondence was coded to a single categorization. However, when it was determined to be a distortion of reality, dual or multiple categorizations were noted. Since contacts so frequently involved more than one participant group, data on participants were ana.. lyzed in two ways: the first employed the Mintzberg method, resulting in combined frequencies exceeding 100 percent; the second adjusted the denominators for number of contacts and contact time so that combined frequencies totaled 100 percent.

There were various problems related to the use of Mintzberg's (1973) structured-observation framework, but the reason for employing it nevertheless is explained well by Pitner (1978):

The contributions of Mintzberg's research and the problematic aspects of his interpretations had to be weighed by this researcher. His framework was followed because it enabled the researcher to 
investigate what administrators do and to ascertain the ordinary organization of the life of incumbents of the superintendency. (p. 78)

The same comment could be made regarding the study of the assistant principalship. In addition, the use of the same approach as used by Pitner (1978) and Crowson and Porter-Gehrie (1980) allowed for a synthesis of comparable findings on three major posts in educational administration.

Besides the problems with using the Mintzberg (1973) framework, there also were problematic aspects to the nonparticipant observer role. First, it was sometimes not possible to actually observe and to record. A few times, the researcher was asked to leave before an activity commenced, such as meetings dealing with sensitive personnel matters. Occasionally, the researcher was not told of an early morning or evening event which the assistant principal attended. Sometimes mail was not recorded if it was inappropriate at the time for the researcher to sit by the assistant principal and a review of the correspondence for the observational records did not take place later. Several times, due to traffic problems, the researcher arrived after the assistant principal's workday began. Both assistant principal and researcher required personal breaks from their work, since the shadowing could span from early in the morning to late at night. Such breaks were often shared coffee breaks. At other times, the assistant principal and observer would separate for a short period of time. The researcher tried to be particularly sensitive to one assistant principal's expressed need for private time during the day. And there were also the "short, dense bursts" of activity Mintzberg (1973, p. 270) alluded to, when it became nearly impossible to capture all 
pertinent information on paper. Once the researcher even found herself without an assistant principal for nearly an hour when three police cars converged and the assistant principal quickly jumped into one in order to identify alleged thieves. In such instances, information was sometimes 10st; more frequently, as much as the assistant principal could remember from direct experience was recounted to the researcher. Certainly every effort was made to appropriately account for all workday activities, whether or not directly observed.

Furthermore, it was at times difficult to maintain the nonparticipant aspect of the nonparticipant observer role. Early in the series of assistant principal observations, an incident occurred which stressed to the researcher both the importance and the difficulty of not participating. A group of students on the school grounds were approached by the assistant principal for alleged possession and use of marijuana. While the assistant principal was speaking to one student, the researcher heard another indicate that he would be "busted" if searched. This information was conveyed to the assistant principal who, as a result, brought school district police into the case. This incident clearly indicated the ease with which a researcher can actually determine the direction of future activity. The assistant principal said, "Don't worry. That happens so many times. We'd do exactiy that." But from that point on, every effort was made to separate the research role from the role of educator and, thus, colleague with the assistant principal. Efforts to achieve a balance between objectivity and rapport were required over and over. Assistant principals at times asked for critiques of their written products or advice for planning an event. A 
secretary asked the researcher to explain some materials to an assistant principal who was occupied at the time. Assistant principals frequently requested that the researcher "take a note," for example to remind them of upcoming meetings. A teacher asked the researcher what she should do with some students involved in an "altercation" while the assistant principal was on the telephone. In short, merely because an adult researcher is present, that person is rather naturally included in transactions that are normal but potentially disruptive to the research role. It was necessary to rapidly analyze each request and determine how best to respond.

Though there were problems in employing both the Mintzberg (1973) framework and the nonparticipant observer role, many potential problems simply never arose to the degree anticipated. Though observed interactions often dealt with sensitive subjects, such as assault, divorce, student dropout, or district politics, rarely was the investigator asked to leave a situation or to refrain from taking notes or reminded to treat information as confidential. And though the researcher was frequentiy present without introduction, few participants inquired in any way about that presence. Finally, instead of finding assistant principals simply enduring study participation demands--of time and invasion of privacy-there was a repeated positive attitude to research involvement. One assistant principal said, "I' 11 miss you tomorrow [no observation scheduled]"; another, "It's so nice to talk to someone who'll let you talk about the job." A third assistant principal, concerned about the stereotypes of inner-city schools, stated, "I wish what you're seeing, other people could see." 
CHAPTER IV

PRESENTATION AND ANALYSIS OF DATA

\begin{abstract}
Introduction
Twenty-five days of observation of the five urban high school assistant principals resulted in approximately 400 pages of handwritten notes-- in the form of miscellaneous field notes, the three observation records, and verbatim notes of structured interviews. In addition, an equal amount of primary reference materials was collected, including such items as resumes, job descriptions, policy statements, teacher and student handbooks, sample forms, and school newspapers. Chapter IV is devoted to presentation and analysis of the interview and observation data. Specifically, this chapter commences with an extended analysis of the comparability of sample members to their counterparts before proceeding to interpretation of the data on the six research subproblems and ends with a synthesis of the similarities of the workdays of assistant principals, principals, and superintendents.
\end{abstract}

\title{
The Sample of Assistant Principals
}

This study's assistant principal sample can be compared to and contrasted with the samples for Austin and Brown's (1970) work. The youngest member of this study's sample was 45 , which is indicative of an older age group than those assistant principals shadowed by Austin 
and Brown, who ranged from 34-58 years of age (p. 16) or those responding to Austin and Brown's normative questionnaire, who were 45 years of age or less in more than half of all cases (p. 29). This older age may be explained, however, by Austin and Brown's finding that urban assistant principals serve a longer waiting period, often in a post between teaching and administration, than do their counterparts in rural or suburban areas (pp. 54-55). A11 five of this study's assistant principals had served in an interim position, such as counselor, activities or athietics director, administrative assistant, or central office post. Austin and Brown determined that half of their normative study respondents had served less than six years as assistant principals (p. 29). Four of the sample members for this study had been assistant principals for under six years also.

All five west coast assistant principals held master's degrees, consistent with Austin and Brown's repeated finding that a very high proportion of assistant principals had completed master's degree programs (pp. 16, 29, 53). Finally, only one out of five of this study's sample was a female. Austin and Brown found that only 14 percent of their urban career study sample was female. In summary, the sample members seem to represent the demographic characteristics of their colleagues quite well.

As previously mentioned in the literature chapter, the literature regarding the assistant principal can be grouped around a few major topics: the asjistant principal's role and the tasks associated with the position, the level of job satisfaction of assistant principals, and the career aspirations of incumbents. In this section, responses to 
the interview questions (complete interview schedule, Appendix B) focusing on these topics are reported in order to determine the degree to which the thoughts of the study's sample members are congruent with the sentiments expressed in the body of literature on the assistant principalship.

Role And Tasks

Subject assistant principals were asked, "What would you say if you were asked to describe the job of assistant principal to someone totally unfamiliar with the position?" Responses that directly replied to the question generally fell into two kinds of descriptions: the generic and the specific. Illustrative of the former type of comment would be the phrase "various duties and responsibilities related to the management of the building" and the statements, "It's primary purpose is to help the school to function in an efficient and satisfactory way"; "The role is to carry out the functions of the organization and its policies." Three of the assistant principals went on to specify the related functions and tasks as planning, administering, decision making, communication, business aspects, public relations, staff relations, student body finances, discipline, assemblies, counseling, special education, teacher evaluation, plant maintenance and security, and athletics. In short, these assistant principals described their roles in very general terms but went on to specify numerous functions and task areas as responsibilities. This broad, somewhat amorphous role description accompanied by the enumeration of an equally broad range of specific responsibilities parallels the notions of assistant principal role and tasks as revealed in the literature. 
A question designed to further probe the general nature of the assistant principalship was also posed: "What kind of person do you think makes a good assistant principal?" Many of the replies were clearly related to the previous role and task descriptions. For example, a repeatedly stated qualification was that the assistant principal must care for, understand, and work well with people. Good assistant principals also, according to the majority of the sample, must be competent in decision-making processes: making decisions and translating their own and others' decisions into appropriate action. Finally, a consistent view was that the assistant principal should have the ability to adapt and, additionally, to respond in ways that allow for stress level to be controlled. As one assistant principal stated, "Like a doctor, you can die with every patient." In responding to this second interview question, then, the group of assistant principals isolated decision-making and human relations--both having a direct relationship to their previous descriptions of the assistant principalship. The ability to be adaptive and flexible and to cope with tension would similarly appear to be necessary outgrowths of a position requiring many decisions and people-to-people interactions.

\section{Job Satisfaction}

The literature on the assistant principal frequently indicates concern with the relatively low level of job satisfaction experienced by assistant principals. Four of the interview questions were, as a result, directed toward this topic. First, interviewees were asked to delineate their own satisfactions and dissatisfactions as assistant principals. There was a marked consistency regarding the gratifications for the 
assistant principal, substantiating the service orientation of the assistant principal noted in the Austin and Brown career study (1970, p. 64). The following responses reveal the consistent orientation to not only serving others but also to perceiving success in the achievement of their altruistic goals:

- Assistant Principal \#1: "Seeing people growing, maturing, solving problems; seeing teachers seeing situation improvement; seeing a kid smiling that hasn't before."

- Assistant Principal \#2: "Just to see the achievement of students."

- Assistant Principal \#3: "I suppose the major satisfaction is when people do well and do what's expected of them."

- Assistant Principal \#4: "That you feel you are contributing something worthwhile to the community; ...that you are assisting people to succeed in endeavors that they are interested in."

- Assistant Principal \#5: "The satisfactions are graduations: you see students who in freshman and sophomore years you worked like the devil to keep in school, and they graduate." The dissatisfactions exposed by the assistant principals are somewhat more varied. One assistant principal catalogued job dissatisfactions as lack of team effort, lack of growth, and the reactive nature of the work. He said, in fact, "We do lots of planning, but each day we are not in control." Another's dissatisfactions stemmed from problems with subordinates: staff division, teachers not following up on administrative directions, and teachers who are not really "members 
of a full educational team." For a third assistant principal, negative responses of teachers, students, and parents regarding decisions were a source of concern. He also highlighted a situation in which his life had been threatened by a student and the accompanying legal actions as a "bummer." Constraints in the areas of money, staffing, and physical facilities were the particulars leading to job dissatisfaction for a fourth assistant principal. The fifth interviewee termed his source of job dissatisfaction as "the misunderstanding that parents have of the responsibilities of the schools," focusing in particular on the "expectations ...that we have all the answers, and it's the school's fault when their son or daughter does not succeed." Though the foregoing comments describe a variety of causes for dissatisfaction, it may be that the diversity is not as great as an initial reading might indicate. Perhaps failure to attain success in service to others is the root of these numerous dissatisfactions. Attainment of altruistic ends is satisfying; conversely, obstacles to such service ends may lead to dissatisfaction.

Since much of the 7 iterature indicated a rather strong belief that relations between principals and assistant principals were a determinant of degree of job satisfaction, sample members were asked, "To what degree and in what ways does the principal affect the assistant principal's level of job satisfaction?" Respondents were unanimously in agreement: the principal has a tremendous impact on the assistant's morale. Assistant principals viewed principal support as vital to job satisfaction. Other elements specified as leading to increased job satisfaction were convergent philosophies of the two administrators; clear decision and directions from the direct superior; openness of the principal; and the 
principal's abilities in delegating, communicating constructive criticism, and creating an atmosphere of team management.

Though the subject is not dealt with in the assistant principal 1iterature, the investigator inquired as to the assistant principal's prior expectations for the job, on the premise that a mismatch between expectations and reality might have been a reason for job dissatisfactions. This did not appear to be the case, however, as all five respondents indicated that the job was as they had expected it to be. The only factor for which one assistant principal had not felt fully prepared was the intensity of the work. He said, "[The job is] exactly what I expected, but much more intense."

\section{Career Plans}

The educational administration literature reveals a state of flux in the career plans of assistant principals as a group: many do not choose to remain in the assistant principalship, though there does appear to be some trend for smal1, but increasing numbers of assistant principals to do so. None of the sample's assistant principals definitely anticipated remaining in the assistant principalship. One is retiring, but may continue to contribute to the field of education by writing a geometry text that would be appropriate for teaching job-related skills to youngsters of low ability. The remaining four all mentioned the possibility of a principalship, though three do so rather tentatively. In alluding to the position of principal, one assistant principal said, "I can't get terribly excited about that." Another respondent stated, "I will not actively seek a principalship. If someone were to come to me and ask me to, I would more than likely respond." He envisioned poten- 
tial opportunities in real-estate development as a serious alternative career option. The fifth assistant principal took a somewhat similar stance: "Whatever comes up, I'll make a decision then." None of the sample members planned to actively seek a principalship. Though the sample is too small to allow generalization or prediction of career trends, their responses cast some doubt on whether the assistant principal is in the position because it is a "step on the way up" as the "assistant-to" position is in other fields (Whistler, pp. 200-201). After Austin and Brown (1970) studied the assistant principalship, they concluded that the assistant principal post may not provide appropriate preparation for the principalship (pp. 75-79). However, Austin (1972), in a reexamination of the previous assistant principal studies, communicated a significant amount of disagreement by practitioners regarding that assertion. The sample in this study revealed sentiments that range between these two views: one, that serving in the assistant principalship does not adequately prepare one for a principalship; and conversely, that prospective principals are appropriately trained by service as assistant principals. Assistant Principal \#1 deemed the assistant's experiences appropriate "on many things, but absolutely not on others," specifically arguing that what hurts many modern leaders is lack of people skills which cannot be learned. Two assistant principals were in agreement that a prospective principal should serve as both an administrative and a curriculum vice-principal. The other two respondents viewed training in the assistant's position as fully qualifying a candidate for the principalship, one stating, "I could step into that position tomorrow and do a credible job." 
of final note regarding the typicality of the observational data, asistant principals were asked what the investigator did not see in the five days of observation. Individuals mentioned specifics such as games, faculty meetings, pre-observation or evaluation conferences with teachers, breakfast meetings, fights, severe discipline problems, calls for security assistance, and medical emergencies. All of these were, however, part of the workdays of one or more of the other assistant principals. The only categories of events mentioned by individuals and ultimately not part of the twenty-five days of observation were: personnel deliberations, visits to boys' locker rooms or lavatories, student forecasting for courses and arena scheduling, social events like a faculty party or TGIF session, and planning for traditional spring events.

The preceding presentation considered the degree to which the sampled assistant principals and observed workdays were representative. In the following six subsections, the results of the structured observations of the sampled assistant principal's workdays are presented and analyzed. When appropriate, the study data are also compared and contrasted to Mintzberg's data on five chief executives (1973). The first consideration is the activities to which an assistant principal's day is devoted.

The Activities of the Assistant Principal's Workday

As described in the methodology chapter, an assistant principal's activities were recorded as scheduled meetings, unscheduled meetings, informational or observational tours, telephone cal1s, or desk work 
(categories explained, Chapter III). Table IV presents the Chronology Record results of 25 days of observation of the five assistant principals (more complete analyses of individual assistant principal's Chronology' Records, Appendix C).

As mentioned previously, nonmanagerial activities were not included in the formal recording of Chronology, Communication, and Contact Records. For example, strictly social lunches and breaks or personal telephone conversations would appear on the Chronology Record as marginal notes onty.

It should be noted also that there is a discrepancy between "total hours worked" and the total of times devoted to each activity. The durations of all individual activities on the Chronology Records were added to yield "total hours worked." However, in the case of simultaneous or interrupting activities, the same time period was counted only once (e.g., if a short telephone call interrupted a long meeting, only meeting time counted). On the other hand, later every activity was assigned its full duration of time (for example, the interrupting telephone call time that was not counted in determining "total hours worked" was counted when "time on telephone" was established). Thus, the totals of "proportion of time" will slightly exceed 100 percent.

In order to attempt to synthesize and interpret the data regarding the activities of the assistant principal, it is instructive to compare the proportion of time devoted to the five activities by the assistant principals and by Mintzberg's chief executives (1973, Table 10, pp. 242-243) as is done in Table $V$. 
TABLE IV

ANALYSIS OF THE CHRONOLOGY RECORO

\begin{tabular}{|c|c|c|c|c|c|c|}
\hline \multicolumn{7}{|c|}{ Hours, ilail, and Activities Total } \\
\hline Category & AP 1 & AP 2 & AP 3 & AP 4 & AP 5 & Composite \\
\hline $\begin{array}{l}\text { Total hours worked } \\
\text { Hours of evening events } \\
\text { (included) } \\
\text { Hours in travel to outside events } \\
\text { (not included) } \\
\text { Total number of activities } \\
\text { Total amount of mail } \\
\text { Average amount of mail processed } \\
\text { per day }\end{array}$ & $\begin{array}{l}37 \mathrm{hr} \\
15 \mathrm{~min} \\
2 \mathrm{hr} \\
50 \mathrm{~min} \\
368 \\
126 \\
25\end{array}$ & $\begin{array}{rl}38 & \mathrm{hr} \\
42 & \mathrm{~min} \\
7 & \mathrm{hr} \\
& \\
1 \mathrm{hr} \\
45 \mathrm{~min} \\
217 & \\
66 & \\
13 & \end{array}$ & $\begin{array}{rl}28 & \mathrm{hr} \\
26 & \mathrm{~min} \\
1 \mathrm{hr} \\
1 \mathrm{hr} \\
25 \mathrm{~min} \\
272 \\
153 \\
31\end{array}$ & $\begin{array}{rl}27 & \mathrm{hr} \\
11 & \mathrm{~min} \\
0 \mathrm{hr} \\
1 \mathrm{hr} \\
8 \mathrm{~min} \\
164 \\
50 \\
30\end{array}$ & $\begin{array}{r}15 \text { min } \\
259 \\
86 \\
17\end{array}$ & $\begin{array}{l}164 \mathrm{hr} \\
10 \mathrm{hr} \\
5 \mathrm{hr} \\
23 \mathrm{~min} \\
1280 \\
581 \\
23\end{array}$ \\
\hline \multicolumn{7}{|c|}{ Desk Work } \\
\hline $\begin{array}{l}\text { Number of sessions } \\
\text { Time on desk work } \\
\text { Average duration } \\
\text { Proportion of time }\end{array}$ & $\begin{array}{l}30 \\
2 \mathrm{hr} \\
45 \text { min } \\
6 \text { min } \\
7 \%\end{array}$ & $\begin{array}{l}32 \\
5 \mathrm{hr} \\
56 \mathrm{~min} \\
11 \mathrm{~min} \\
15 \%\end{array}$ & $\begin{array}{l}46 \\
5 \mathrm{hr} \\
28 \mathrm{~min} \\
7 \mathrm{~min} \\
19 \%\end{array}$ & $\begin{array}{r}33 \\
7 \mathrm{hr} \\
12 \mathrm{~min} \\
13 \mathrm{~min} \\
26 \%\end{array}$ & $\begin{array}{l}38 \\
5 \mathrm{hr} \\
53 \mathrm{~min} \\
9 \mathrm{~min} \\
18 \%\end{array}$ & $\begin{array}{l}179 \\
27 \text { hr } \\
14 \text { min } \\
9 \text { min } \\
17 \%\end{array}$ \\
\hline \multicolumn{7}{|c|}{ Telephone Calls } \\
\hline $\begin{array}{l}\text { Number of calls } \\
\text { Time on telephone } \\
\text { Average duration } \\
\text { Proportion of time }\end{array}$ & $\begin{array}{l}101 \\
4 \mathrm{hr} \\
1 \mathrm{~min} \\
2 \mathrm{~min} \\
11 \%\end{array}$ & $\begin{array}{l}48 \\
1 \mathrm{hr} \\
27 \mathrm{~min} \\
2 \mathrm{~min} \\
4 \%\end{array}$ & $\begin{array}{l}62 \\
2 \mathrm{hr} \\
2 \mathrm{~min} \\
2 \mathrm{~min} \\
7 \%\end{array}$ & $\begin{array}{l}33 \\
1 \mathrm{hr} \\
11 \mathrm{~min} \\
2 \mathrm{~min} \\
4 \%\end{array}$ & $\begin{array}{l}28 \\
53 \min \\
2 \text { min } \\
3 \%\end{array}$ & $\begin{array}{l}272 \\
9 \mathrm{hr} \\
34 \mathrm{~min} \\
2 \mathrm{~min} \\
6 \%\end{array}$ \\
\hline \multicolumn{7}{|c|}{ Scheduled Meetings } \\
\hline $\begin{array}{l}\text { Number of meetings } \\
\text { Time in meetings } \\
\text { Average duration } \\
\text { Proportion of time }\end{array}$ & $\begin{array}{l}9 \\
4 \mathrm{hr} \\
46 \mathrm{~min} \\
32 \mathrm{~min} \\
13 \%\end{array}$ & $\begin{array}{l}18 \\
13 \mathrm{hr} \\
21 \mathrm{~min} \\
45 \mathrm{~min} \\
34 \%\end{array}$ & $\begin{array}{l}17 \\
7 \mathrm{hr} \\
32 \mathrm{~min} \\
27 \mathrm{~min} \\
26 \%\end{array}$ & $\begin{array}{l}14 \\
9 \mathrm{hr} \\
36 \mathrm{~min} \\
41 \mathrm{~min} \\
35 \%\end{array}$ & $\begin{array}{l}7 \\
4 \mathrm{hr} \\
7 \mathrm{~min} \\
35 \mathrm{~min} \\
13 \%\end{array}$ & $\begin{array}{l}65 \\
39 \mathrm{hr} \\
22 \mathrm{~min} \\
36 \mathrm{~min} \\
24 \%\end{array}$ \\
\hline \multicolumn{7}{|c|}{ Unscheduled Meetings } \\
\hline $\begin{array}{l}\text { Number of meetings } \\
\text { Time in meetings } \\
\text { Average duration } \\
\text { Proportion of time }\end{array}$ & $\begin{array}{l}158 \\
12 \mathrm{hr} \\
36 \mathrm{~min} \\
5 \mathrm{~min} \\
34 \%\end{array}$ & $\begin{array}{l}70 \\
3 \mathrm{hr} \\
44 \mathrm{~min} \\
3 \mathrm{~min} \\
10 \%\end{array}$ & $\begin{array}{l}90 \\
7 \mathrm{hr} \\
15 \mathrm{~min} \\
4 \mathrm{~min} \\
25 \%\end{array}$ & $\begin{array}{l}53 \\
5 \mathrm{hr} \\
7 \mathrm{~min} \\
6 \mathrm{~min} \\
19 \%\end{array}$ & $\begin{array}{l}109 \\
11 \mathrm{hr} \\
2 \mathrm{~min} \\
6 \mathrm{~min} \\
34 \%\end{array}$ & $\begin{array}{l}489 \\
39 \text { hr } \\
44 \text { min } \\
5 \text { min } \\
24 \%\end{array}$ \\
\hline \multicolumn{7}{|c|}{ Tours } \\
\hline $\begin{array}{l}\text { Numbers of tours } \\
\text { Time on tours } \\
\text { Average duration } \\
\text { Proportion of time }\end{array}$ & $\begin{array}{l}70 \\
17 \mathrm{hr} \\
31 \mathrm{~min} \\
15 \mathrm{~min} \\
47 \%\end{array}$ & $\begin{array}{l}49 \\
15 \mathrm{hr} \\
6 \mathrm{~min} \\
18 \mathrm{~min} \\
39 \%\end{array}$ & $\begin{array}{l}48 \\
7 \mathrm{hr} \\
9 \mathrm{~min} \\
25 \%\end{array}$ & $\begin{array}{l}31 \\
4 \mathrm{hr} \\
33 \mathrm{~min} \\
9 \mathrm{~min} \\
17 \%\end{array}$ & $\begin{array}{l}77 \\
11 \mathrm{hr} \\
53 \mathrm{~min} \\
9 \mathrm{~min} \\
37 \%\end{array}$ & $\begin{array}{l}275 \\
56 \mathrm{hr} \\
3 \mathrm{~min} \\
12 \mathrm{~min} \\
34 \%\end{array}$ \\
\hline \multicolumn{7}{|c|}{ Length of Activities } \\
\hline $\begin{array}{l}\text { Proportion of activities lasting } \\
\text { less than } 9 \text { minutes }\end{array}$ & $78 \%$ & $70 \%$ & $83 \%$ & $66 \%$ & $71 \%$ & $75 \%$ \\
\hline $\begin{array}{l}\text { Proportion lasting longer than } \\
60 \text { minutes }\end{array}$ & $1 \%$ & $4 \%$ & $1 \%$ & $1 \%$ & 19 & $1 \%$ \\
\hline
\end{tabular}


TABLE V

COMPARISON OF PROPORTIONS OF TIME DEVOTED TO

ACTIVITIES BY ASSISTANT PRINCIPALS AND

MINTZBERG'S CHIEF EXECUTIVES

\begin{tabular}{lcc}
\hline \hline Activity & Assistant Principals & $\begin{array}{c}\text { Chief } \\
\text { Executives }\end{array}$ \\
\hline Desk work & $17 \%$ & $22 \%$ \\
Telephone calls & $6 \%$ & $6 \%$ \\
Scheduled meetings & $24 \%$ & $59 \%$ \\
Unscheduled meetings & $24 \%$ & $10 \%$ \\
Tours & $34 \%$ & $3 \%$ \\
\hline
\end{tabular}

The assistant principals and the chief executives are quite comparable in the proportion of time devoted to telephone conversations and to paper work. It is in the other three activities that marked discrepancies exist. Through consideration of these differences, the specific and rather special nature of the activities of the assistant principal's school day emerge.

Mintzberg (1973) concluded, "The scheduled meeting consumes more of the manager's time than any other medium" (p. 52). Though one-fourth (24\%) of the assistant principal's day is spent in scheduled meetings, for the chief executive the proportion is nearly 60 percent $(59 \%)$. If the assistant principal is not a formal meeting-goer to the extent that the chief executive is, then to what activities does the assistant principal devote the majority of time? Clearly the answer lies in the unscheduled meeting and tour categories. While only 10 percent of the chief executive time is spent in the hastily-arranged unscheduled meeting, 
the assistant principal spends one-quarter (24\%) of the day in short, unscheduled meetings--an equal amount of time to that of the more forma?, lengthy scheduled meeting (30 minutes average duration as compared to five minutes).

But even more dramatic is the difference in touring time. Mintzberg (1973) determined with chief executives that, "The manager spends little of his time in open-ended touring" (p. 52). A mere three percent of workday time is spent on tour. However, for the assistant principal, more than a third (34\%) of the workday is concentrated in the tour category, this being the highest activity medium of all for the assistant principal. Since, in the composite sample, the tour accounts for more time expenditure than any other activity, subjects' comments as recorded in field and interview notes were studied to determine the reasons for such an emphasis. Three of the assistant principals used precisely the same word to explain the rationale for numerous observational tours--visibility. In fact, one said, "That's my m.o..visibility!" Numerous belief statements by assistant principals explain further the rather consistent reasons that such visibility is considered critical. Assistant principals felt the tour aids in the prevention of problems. As one person stated, "Calling kids by their names is a great preventive measure." Another was in the halls in the mornings to "set the tone for the day"; and throughout the day, he repeatedly visited the same spots, places where problem situations had developed in the past: fires, smoking in restricted areas of campus, or drug dealing. 
Though the tour is used little by the chief executives in Mintzberg's (1973) study, Crowson and Porter-Gehrie (1980) labeled one of the coping mechanisms employed by urban principals "maintaining a presence in the school." Their description of this mechanism could equally as well apply to vice-principals:

Principals also appear to cope with constraints upon their time by asserting their presence in the school through a series of quick, brief search routines. Both elementary and high school principals spot-check the hal lways and corridors of their buildings during various passing periods of the day. During the lunch hour, many principals stay visibly within range of the school cafeteria and the school playground. Such contacts provide an opening for questions, comments, and special requests.

Although seeming a time-consuming rather than time-saving activity, the search routine provides a chance for the principal to maintain a presence in the school and, through his or her patrolling behavior, anticipate and quell potential trouble. (p. 52)

Anything can happen on a tour, whether observational or informational, and assistant principals know that. To illustrate, one assistant principal said, when choosing to end a tour, "I don't want to look for any more trouble." To a great degree, this "open-ended touring" (Mintzberg, 1973, p. 52) accounts for the fluidity of the assistant principal's day. In fact, one assistant principal made specific note of this very aspect of the workday, saying, "It's all so fluid." An assistant principal sets out on a routine tour that may eventually lead to a series of other activities--meetings, telephone calls, and desk work. For example, on one tour an assistant principal encountered students with marijuana pipes. This incident led to numerous other contacts: several meetings with individual students to ascertain the 
facts, one large meeting (with all students, another assistant principal, and a school district policeman) to communicate what future actions would be taken, and telephone calls to various parents to alert them to their children's conduct.

Given that 58 percent of the assistant principal's time is given to unscheduled meetings or tours, the following quotation from Mintzberg's (1973) "propositions about managerial work characteristics" surely can be directly applied to the assistant principal:

The manager gravitates to the more active elements of his work--the current, the non-routine.... The pressure of the job does not encourage the development of a planner, but of an adaptive environment manipulator who lives in a stimulus-response environment and who favors live action. (pp. 51-52)

\section{The Duration of the Assistant Principal's Workday}

Though the Chronology Record (Table IV) indicates "total hours worked," further calculations were necessary in order to accurately portray the daily hours worked by assistant principals, since the method used to calculate "total hours worked" excluded all non-managerial work. Non-business lunches, coffee breaks, personal telephone calls, and errands do consume parts of a manager's time, though these activities would not be classified as managerial work. In addition, simply because an investigator was present, a fairly substantial amount of each assistant principal's time was devoted to researcher questions and to conversations regarding the background of observed events. Thus, Table VI provides necessary additional information regarding the true length of the assistant principal's workday. 
TABLE VI

DURATION OF THE WORK WEEK AND WORKDAY OF ASSISTANT PRINCIPALS

\begin{tabular}{lllllll}
\hline & AP 1 & AP 2 & AP 3 & AP 4 & AP 5 & $\begin{array}{c}\text { Composite } \\
\text { average }\end{array}$ \\
\hline Duration of work week & $45 \mathrm{hr}$ & $48 \mathrm{hr} 41 \mathrm{hr} 39 \mathrm{hr} 38 \mathrm{hr}$ & $42 \mathrm{hr}$ \\
$5 \mathrm{~min}$ & $42 \mathrm{~min} 33 \mathrm{~min} 11 \mathrm{~min} 15 \mathrm{~min}$ & $33 \mathrm{~min}$ \\
$\begin{array}{l}\text { Duration of average } \\
\text { workday }\end{array}$ & $9 \mathrm{hr} 9 \mathrm{hr} 8 \mathrm{hr} 7 \mathrm{hr} 7 \mathrm{hr}$ & $8 \mathrm{hr}$ \\
$\begin{array}{l}\text { Duration of average } \\
\text { non-business lunch } \\
\text { (included) }\end{array}$ & $39 \mathrm{~min} 26 \mathrm{~min} 55 \mathrm{~min} 47 \mathrm{~min} 35 \mathrm{~min}$ & $41 \mathrm{~min}$ \\
\hline
\end{tabular}

For this table, the duration of each assistant principal's work week was first calculated by ascertaining the total number of hours involved from the starting point of the first work activity of each day to the ending point of the last activity of the day. If an evening event allowed for the assistant principal to go home between day and evening activities, that free time was excluded. The total work week hours were then divided by five in order to determine the duration of the average workday.

At first glance, it might appear that a comparison of the "total hours worked" (Table IV) and the average duration of the full work week (Table VI) indicates marked discrepancy; that, in fact, assistant principals waste a fair amount of their work week. As a result, it is important that the discrepancy be clarified. For the composite sample's 25 observation days, "total hours worked" was 164, or approximately 33 hours per week per assistant principal; the average full work week was approximately 42.5 hours, leaving a difference of 9.5 hours, or 114 
minutes per day. However, 'if an assistant principal each day took a 40 minute lunch and two 15-minute coffee breaks, made a five-minute personal telephone call, spent five minutes in the restroom, and 34 minutes (approximately four minutes per hour, in an eight-hour day) in discussion/explanation with the researcher, this accounted for al1 114 minutes. During the observation time, subject assistant principal's average workdays ranged from approximately 7.5 hours to nearly 10 hours in duration, with the composite sample averaging approximately 8.5 work hours per day. These results were consistent with interviewee descriptions of their typical working hours including evenings and weekends. All five stated that the typical workday is approximately eight hours 1ong. The work week, they explained, at times exceeded the normal 40 hours because of various early morning, evening and weekend events, such as athletic contests, professional organization events, student activities, reading to keep current in the field, and meetings of parent groups. Not all respondents attempted to quantify the frequency of these additional events, but those that did estimated an average of one early morning event per month, one to two nights per week, one to two Saturdays per month, and two Sundays per year. Since both the investigator's observations and the comments of subjects indicated that work week was only slightly longer than the classic American forty-hour work week, it would appear that job dissatisfactions and stresses are likely not the result of excessively long hours. 
The Pace of the Assistant Principal's Workday

Sampled assistant principals, when interviewed, were asked, "How might the pace of your job be described?" The adjectives employed by respondents--brisk, rapid, fast-moving--communicated a uniform view of the pace of the workday of the urban high school assistant principal. This consistent description parallels one of Mintzberg's (1973) managerial work propositions: that, "[Activities] of the manager are characterized by brevity, variety, and fragmentation" (p. 51).

One indication of the pace of a day is simultaneous and/or interrupting activities. As noted previously, it was impossible to treat the time duration of some activities as discrete entities, as activities took place simultaneously. One assistant principal vividly captured this aspect of the workday with the following comment: "Sometimes the phone's ringing, parents are here, a teacher is standing in the door, and even the intercom's ringing."

The characteristics of brevity and fragmentation are even more pronounced with assistant principals than they are with chief executives, consistent with Mintzberg's (1973) contention regarding managers at lower levels in the hierarchy (p. 113). Table VII, which provides comparative data from the Chronology Records of assistant principals and Mintzberg's chief executives (1973, Table 10, pp. 242-243) isolates various indicators of both brevity and fragmentation. 
TABLE VII

COMPARISON OF INDICATORS OF BREVITY/FRAGMENTATION IN THE WORKDAYS OF ASSISTANT PRINCIPALS AND MINTZBERG'S CHIEF EXECUTIVES

\begin{tabular}{lcc}
\hline & $\begin{array}{c}\text { Assistant } \\
\text { Principals }\end{array}$ & $\begin{array}{l}\text { Chief } \\
\text { Executives }\end{array}$ \\
\hline Total number of activities & 1280 & 547 \\
Average Duration & & \\
Desk work & $9 \mathrm{~min}$ & $15 \mathrm{~min}$. \\
Telephone cal1s & $2 \mathrm{~min}$ & $6 \mathrm{~min}$ \\
Scheduled meetings & $36 \mathrm{~min}$ & $68 \mathrm{~min}$ \\
Unscheduled meetings & $5 \mathrm{~min}$ & $12 \mathrm{~min}$ \\
Tours & $12 \mathrm{~min}$ & $11 \mathrm{~min}$ \\
Proportion of activities lasting & $75 \%$ & \\
Tess than 9 min. & & $49 \%$ \\
Proportion of activities lasting & $1 \%$ & $10 \%$ \\
more than 60 min. & & \\
\hline
\end{tabular}

Mintzberg's (1973) first proposition on managerial work characteristics isolated the aspect of hectic pace of the manager's workday ( $p$. 51). Table VII indicates that any statement that can be made about the pace of the chief executive's day can be made in even stronger terms about the assistant principal's daily pace. In twenty-five days of observation, chief executives were involved in 547 separate activities; that number was more than doubled (1280) for assistant principals. Logically, it would follow that the average duration of the five categories of activities would be shorter for assistant principals than for chief executives. The chief executives' average desk work session was 15 minutes long; for assistant principals, it was nine minutes. The mean durations of telephone calls were six and two minutes for chief executives and assistant principals, respectively. The chief executive's average 
scheduled meeting was nearly twice the length of the assistant principal's (68 minutes and 36 minutes). The average unscheduled meeting lasted 12 minutes for the chief executive, five for the assistant principal. Only for the tour was the average time devoted by the two managers very similar (11 minutes and 12 minutes). The final two indicators of the pace of the workday are the percentage figures for the short and long activities. Although less than half (49\%) of the chief executive's activities lasted less than nine minutes; for the assistant principal, 75 percent of all activities were less than nine minutes in duration. Only 10 percent of the chief executive's activities were 60 minutes or longer, but the proportion for assistant principals was a meager one percent. The assistant principal often moved from short event to short event at an almost unbelieveable pace.

In addition to the data substantiating Mintzberg's (1973) premise of "brevity, variety, and fragmentation" (p. 51), certain assistant principal's comments also provide information as to why Mintzberg made the rather provocative statement that, "The manager actually appears to prefer brevity and interruption in his work" (p. 51). For example, one assistant principal commented, "Notice I always jump around [from one activity to another]. That's what hooks me on these kinds of jobs. Anything else would be tame afterwards." Another stated, "I don't really know where the time goes. That's the part that's good about the job." However, he went on to say, "That's also a source of frustration." Pitner (1978) took issue with Mintzberg's (1973) statement that, "The manager feels compelled to perform a greater quantity of work at an unrelenting pace" (p. 51). Pitner (1978) stated, "While superinten- 
dents are busy, the superintendent does not maintain an unyielding pace of activities. He experiences periods of intensity and variety as well as depressed cycles of activity" ( $p .99)$. This statement could be accurately applied to assistant principals as well.

The two periods of the day in which the pace typically slowed down were during lunch and after the last class ended. Lunches, when at school, were relatively short (range: 26-55 minutes). However, the majority of assistant principals clearly stated that they attempted to make their lunch periods a time for relaxation. One said he prefers to go to lunch when teachers are not there, apparently to reduce the possibility of dealing with work-related matters during that time. Another said, "I try to make lunch strictly social." A third assistant principal stated his approach even more strongly: "I don't discuss business at Tunch."

At the end of the workday, there was often another opportunity for the pace to slow down marked7y. This depressed period of activity was noted by three of the assistant principals. One assistant principal, at 3:55 one afternoon, pointed out, "This is a quiet time of day, because no one's here." Another called a rather slow-paced late afternoon "coasting," saying, "You deserve it when from eight to three you're going constantly." The third vice-principal, who had an extended day because of a game he would be attending, said, "What I'm really kind of doing is loafing the rest of the day." 
The Assistant Principal's Workday Interactions

One of the major research questions, stated in three parts, was: With whom does an assistant principal interact? How? Why? Tables VIII, IX, and $X$ provide the basic data for answering this three-part question by delineating various aspects of the Communication and Contact Records (more complete analyses of these records for each assistant principal, Appendixes D-F).

TABLE VIII

ANALYSIS OF THE MAIL RECORD: INPUT

\begin{tabular}{|c|c|c|c|c|c|c|}
\hline Category & AP 1 & AP 2 & AP 3 & AP 4 & AP 5 & Composite \\
\hline Number of pieces received & 80 & 49 & 103 & 113 & 54 & 399 \\
\hline \multicolumn{7}{|c|}{ Form of Input } \\
\hline $\begin{array}{l}\text { Note } \\
\text { Form } \\
\text { Memo } \\
\text { Letter } \\
\text { Paper } \\
\text { Report } \\
\text { Brochure } \\
\text { Book } \\
\text { Handbook } \\
\text { Courtesy Copy } \\
\text { Newsletter } \\
\text { Periodical } \\
\text { Clipping } \\
\text { Carbon copy of letter, } \\
\text { memo, form, or note } \\
\text { Forwarded letter or memo } \\
\text { Miscellaneous }\end{array}$ & $\begin{array}{r}10 \% \\
44 \% \\
5 \% \\
6 \% \\
0 \% \\
23 \% \\
0 \% \\
0 \% \\
0 \% \\
4 \% \\
0 \% \\
4 \% \\
0 \% \\
5 \% \\
\\
0 \% \\
0 \%\end{array}$ & $\begin{array}{r}8 \% \\
13 \% \\
8 \% \\
10 \% \\
0 \% \\
4 \% \\
2 \% \\
0 \% \\
2 \% \\
2 \% \\
4 \% \\
20 \% \\
0 \% \\
4 \% \\
10 \% \\
6 \%\end{array}$ & $\begin{array}{r}6 \% \\
35 \% \\
5 \% \\
1 \% \\
0 \% \\
1 \% \\
0 \% \\
0 \% \\
0 \% \\
1 \% \\
1 \% \\
0 \% \\
0 \% \\
44 \% \\
0 \% \\
7 \%\end{array}$ & $\begin{array}{r}14 \% \\
27 \% \\
12 \% \\
4 \% \\
1 \% \\
1 \% \\
4 \% \\
1 \% \\
1 \% \\
7 \% \\
4 \% \\
5 \% \\
0 \% \\
3 \% \\
\\
2 \% \\
13 \%\end{array}$ & $\begin{array}{r}7 \% \\
43 \% \\
13 \% \\
0 \% \\
0 \% \\
2 \% \\
2 \% \\
0 \% \\
2 \% \\
6 \% \\
2 \% \\
9 \% \\
0 \% \\
2 \% \\
2 \% \\
2 \% \\
11 \%\end{array}$ & $\begin{array}{r}10 \% \\
34 \% \\
9 \% \\
4 \% \\
0 \% \\
6 \% \\
2 \% \\
0 \% \\
1 \% \\
4 \% \\
2 \% \\
6 \% \\
0 \% \\
14 \% \\
2 \% \\
8 \%\end{array}$ \\
\hline \multicolumn{7}{|c|}{ Attention } \\
\hline $\begin{array}{l}\text { Glance } \\
\text { Skim } \\
\text { Read } \\
\text { Study }\end{array}$ & $\begin{array}{r}38 \% \\
41 \% \\
20 \% \\
0 \%\end{array}$ & $\begin{array}{r}33 \% \\
14 \% \\
53 \% \\
0 \%\end{array}$ & $\begin{array}{r}44 \% \\
12 \% \\
43 \% \\
1 \%\end{array}$ & $\begin{array}{r}26 \% \\
30 \% \\
43 \% \\
1 \%\end{array}$ & $\begin{array}{r}33 \% \\
20 \% \\
46 \% \\
0 \%\end{array}$ & $\begin{array}{r}35 \% \\
24 \% \\
40 \% \\
1 \%\end{array}$ \\
\hline
\end{tabular}


TABLE VIII (continued)

\begin{tabular}{|c|c|c|c|c|c|c|}
\hline Category & AP 1 & AP 2 & AP 3 & AP 4 & AP 5 & Composite \\
\hline $\begin{array}{l}\text { Write } \\
\text { Proof }\end{array}$ & $\begin{array}{l}1 \% \\
0 \%\end{array}$ & $\begin{array}{l}0 \% \\
0 \%\end{array}$ & $\begin{array}{l}0 \% \\
1 \%\end{array}$ & $\begin{array}{l}0 \% \\
0 \%\end{array}$ & $\begin{array}{l}0 \% \\
0 \%\end{array}$ & $\begin{array}{l}0 \% \\
0 \%\end{array}$ \\
\hline \multicolumn{7}{|c|}{ Sender } \\
\hline $\begin{array}{l}\text { External board } \\
\text { Director } \\
\text { District support } \\
\text { Superior } \\
\text { Subordinate A } \\
\text { Subordinate B } \\
\text { Peer A } \\
\text { Peer B } \\
\text { Peer C } \\
\text { Client } \\
\text { Trade organization } \\
\text { Supplier or associate } \\
\text { Publisher } \\
\text { Government } \\
\text { Independent }\end{array}$ & $\begin{array}{r}0 \% \\
0 \% \\
16 \% \\
10 \% \\
60 \% \\
1 \% \\
3 \% \\
0 \% \\
0 \% \\
4 \% \\
3 \% \\
3 \% \\
0 \% \\
1 \% \\
0 \%\end{array}$ & $\begin{array}{r}10 \% \\
0 \% \\
6 \% \\
14 \% \\
41 \% \\
0 \% \\
0 \% \\
0 \% \\
0 \% \\
10 \% \\
6 \% \\
8 \% \\
0 \% \\
4 \% \\
0 \%\end{array}$ & $\begin{array}{r}0 \% \\
0 \% \\
3 \% \\
3 \% \\
91 \% \\
0 \% \\
0 \% \\
0 \% \\
0 \% \\
1 \% \\
2 \% \\
0 \% \\
0 \% \\
0 \% \\
0 \%\end{array}$ & $\begin{array}{r}0 \% \\
0 \% \\
11 \% \\
9 \% \\
51 \% \\
0 \% \\
4 \% \\
2 \% \\
0 \% \\
3 \% \\
15 \% \\
5 \% \\
0 \% \\
0 \% \\
7 \%\end{array}$ & $\begin{array}{r}0 \% \\
0 \% \\
4 \% \\
13 \% \\
67 \% \\
0 \% \\
0 \% \\
6 \% \\
0 \% \\
6 \% \\
0 \% \\
2 \% \\
0 \% \\
2 \% \\
2 \%\end{array}$ & $\begin{array}{r}1 \% \\
0 \% \\
8 \% \\
9 \% \\
64 \% \\
0 \% \\
2 \% \\
1 \% \\
0 \% \\
4 \% \\
6 \% \\
3 \% \\
0 \% \\
1 \% \\
1 \%\end{array}$ \\
\hline \multicolumn{7}{|c|}{ Purpose of Input Mail } \\
\hline $\begin{array}{l}\text { Acknowl edgements } \\
\text { Status requests } \\
\text { Solicitations } \\
\text { Authority requests } \\
\text { Total requests } \\
\text { Reference data } \\
\text { General reports } \\
\text { Periodical news } \\
\text { Events } \\
\text { Reports on operations } \\
\text { Advice on situations } \\
\text { Problems and pressures } \\
\text { Ideas } \\
\text { Total information } \\
\text { Total miscellaneous }\end{array}$ & $\begin{array}{r}5 \% \\
0 \% \\
8 \% \\
38 \% \\
51 \% \\
35 \% \\
4 \% \\
4 \% \\
0 \% \\
0 \% \\
0 \% \\
6 \% \\
1 \% \\
50 \% \\
0 \%\end{array}$ & $\begin{array}{r}2 \% \\
8 \% \\
10 \% \\
2 \% \\
22 \% \\
16 \% \\
6 \% \\
24 \% \\
20 \% \\
0 \% \\
2 \% \\
8 \% \\
0 \% \\
76 \% \\
2 \%\end{array}$ & $\begin{array}{r}0 \% \\
3 \% \\
3 \% \\
24 \% \\
30 \% \\
57 \% \\
0 \% \\
1 \% \\
2 \% \\
0 \% \\
0 \% \\
10 \% \\
0 \% \\
70 \% \\
0 \%\end{array}$ & $\begin{array}{r}6 \% \\
3 \% \\
14 \% \\
13 \% \\
47 \% \\
37 \% \\
1 \% \\
8 \% \\
7 \% \\
0 \% \\
2 \% \\
0 \% \\
4 \% \\
59 \% \\
0 \%\end{array}$ & $\begin{array}{r}2 \% \\
0 \% \\
2 \% \\
9 \% \\
13 \% \\
48 \% \\
0 \% \\
11 \% \\
0 \% \\
0 \% \\
0 \% \\
28 \% \\
0 \% \\
87 \% \\
0 \%\end{array}$ & $\begin{array}{r}3 \% \\
3 \% \\
8 \% \\
20 \% \\
34 \% \\
47 \% \\
2 \% \\
3 \% \\
5 \% \\
0 \% \\
1 \% \\
9 \% \\
1 \% \\
66 \% \\
0 \%\end{array}$ \\
\hline
\end{tabular}


TABLE IX

ANALYSIS OF THE MAIL RECORD: OUTPUT

\begin{tabular}{|c|c|c|c|c|c|c|}
\hline Category & AP 1 & AP 2 & AP 3 & AP 4 & AP 5 & Composite \\
\hline \multicolumn{7}{|c|}{ Output Volume and Initiation } \\
\hline $\begin{array}{l}\text { Number reactions to inputs } \\
\text { Number self-initiated } \\
\text { Total output } \\
\text { Output as percent of input } \\
\text { Self-initiated as percent } \\
\text { of output }\end{array}$ & $\begin{array}{l}18 \\
28 \\
46 \\
58 \% \\
61 \%\end{array}$ & $\begin{array}{c}9 \\
8 \\
17 \\
35 \% \\
47 \%\end{array}$ & $\begin{array}{l}31 \\
19 \\
50 \\
49 \% \\
38 \%\end{array}$ & $\begin{array}{l}25 \\
12 \\
37 \\
33 \% \\
32 \%\end{array}$ & $\begin{array}{l}12 \\
20 \\
32 \\
59 \% \\
63 \%\end{array}$ & $\begin{array}{c}95 \\
87 \\
182 \\
46 \% \\
48 \%\end{array}$ \\
\hline \multicolumn{7}{|c|}{ Form of Output Mai1 } \\
\hline $\begin{array}{l}\text { Note } \\
\text { Form } \\
\text { Memo } \\
\text { Letter } \\
\text { Paper } \\
\text { Report } \\
\text { Brochure } \\
\text { Book } \\
\text { Handbook } \\
\text { Courtesy copy } \\
\text { Newsletter } \\
\text { Periodical } \\
\text { Clipping } \\
\text { Carbon copy of letter, } \\
\text { memo, or note } \\
\text { Forwarded items } \\
\text { Miscellaneous }\end{array}$ & $\begin{array}{r}9 \% \\
48 \% \\
15 \% \\
13 \% \\
0 \% \\
9 \% \\
0 \% \\
0 \% \\
2 \% \\
0 \% \\
0 \% \\
0 \% \\
0 \% \\
4 \% \\
0 \% \\
0 \%\end{array}$ & $\begin{array}{r}17 \% \\
24 \% \\
29 \% \\
0 \% \\
0 \% \\
0 \% \\
0 \% \\
0 \% \\
12 \% \\
6 \% \\
0 \% \\
0 \% \\
0 \% \\
0 \% \\
0 \% \\
12 \%\end{array}$ & $\begin{array}{r}6 \% \\
66 \% \\
0 \% \\
24 \% \\
0 \% \\
0 \% \\
0 \% \\
0 \% \\
2 \% \\
0 \% \\
0 \% \\
0 \% \\
0 \% \\
0 \% \\
0 \% \\
2 \%\end{array}$ & $\begin{array}{r}30 \% \\
32 \% \\
5 \% \\
3 \% \\
0 \% \\
0 \% \\
0 \% \\
0 \% \\
0 \% \\
0 \% \\
0 \% \\
0 \% \\
0 \% \\
0 \% \\
30 \% \\
0 \%\end{array}$ & $\begin{array}{r}9 \% \\
78 \% \\
6 \% \\
3 \% \\
0 \% \\
0 \% \\
0 \% \\
0 \% \\
0 \% \\
0 \% \\
0 \% \\
0 \% \\
0 \% \\
0 \% \\
0 \% \\
3 \%\end{array}$ & $\begin{array}{r}13 \% \\
53 \% \\
9 \% \\
11 \% \\
0 \% \\
2 \% \\
0 \% \\
0 \% \\
2 \% \\
1 \% \\
0 \% \\
0 \% \\
0 \% \\
1 \% \\
6 \% \\
2 \%\end{array}$ \\
\hline \multicolumn{7}{|c|}{ Target of Output Mail } \\
\hline $\begin{array}{l}\text { External board } \\
\text { Director } \\
\text { District support } \\
\text { Superior } \\
\text { Subordinate A } \\
\text { Subordinate B } \\
\text { Peer A } \\
\text { Peer B } \\
\text { Peer C } \\
\text { Client } \\
\text { Trade organization } \\
\text { Supplier or associate } \\
\text { Publisher } \\
\text { Government } \\
\text { Independent }\end{array}$ & $\begin{array}{r}0 \% \\
0 \% \\
7 \% \\
0 \% \\
67 \% \\
0 \% \\
7 \% \\
4 \% \\
0 \% \\
15 \% \\
0 \% \\
0 \% \\
0 \% \\
0 \% \\
2 \%\end{array}$ & $\begin{array}{r}12 \% \\
0 \% \\
6 \% \\
18 \% \\
47 \% \\
24 \% \\
6 \% \\
0 \% \\
0 \% \\
0 \% \\
0 \% \\
0 \% \\
0 \% \\
0 \% \\
0 \%\end{array}$ & $\begin{array}{r}0 \% \\
0 \% \\
0 \% \\
0 \% \\
78 \% \\
0 \% \\
0 \% \\
0 \% \\
0 \% \\
0 \% \\
24 \% \\
0 \% \\
2 \% \\
0 \% \\
0 \% \\
0 \%\end{array}$ & $\begin{array}{r}0 \% \\
0 \% \\
3 \% \\
5 \% \\
92 \% \\
0 \% \\
0 \% \\
0 \% \\
0 \% \\
0 \% \\
0 \% \\
3 \% \\
3 \% \\
0 \% \\
0 \% \\
0 \%\end{array}$ & $\begin{array}{r}0 \% \\
0 \% \\
0 \% \\
0 \% \\
100 \% \\
0 \% \\
0 \% \\
0 \% \\
0 \% \\
0 \% \\
0 \% \\
0 \% \\
0 \% \\
0 \% \\
0 \%\end{array}$ & $\begin{array}{r}1 \% \\
0 \% \\
3 \% \\
3 \% \\
79 \% \\
2 \% \\
2 \% \\
2 \% \\
1 \% \\
0 \% \\
10 \% \\
1 \% \\
1 \% \\
0 \% \\
0 \% \\
0 \% \\
1 \%\end{array}$ \\
\hline
\end{tabular}


TABLE IX (continued)

\begin{tabular}{|c|c|c|c|c|c|c|}
\hline Category & AP 1 & AP 2 & AP 3 & AP 4 & AP 5 & Composite \\
\hline \multicolumn{7}{|c|}{ Purpose of Output Mail } \\
\hline Acknowledge input & $0 \%$ & $0 \%$ & $0 \%$ & $0 \%$ & $0 \%$ & $0 \%$ \\
\hline $\begin{array}{l}\text { Write to third party } \\
\text { re: input, decision, or } \\
\text { situation }\end{array}$ & $0 \%$ & $0 \%$ & $0 \%$ & $0 \%$ & $0 \%$ & $0 \%$ \\
\hline Reply to information received & $4 \%$ & $6 \%$ & $20 \%$ & $3 \%$ & $9 \%$ & $9 \%$ \\
\hline Forward information to subord. & $13 \%$ & $12 \%$ & $0 \%$ & $24 \%$ & $6 \%$ & $10 \%$ \\
\hline Reply to written request & $7 \%$ & $0 \%$ & $26 \%$ & $27 \%$ & $6 \%$ & $15 \%$ \\
\hline Forward request to subord. & $2 \%$ & $18 \%$ & $0 \%$ & $11 \%$ & $13 \%$ & $7 \%$ \\
\hline $\begin{array}{l}\text { Acknowledge or reply to } \\
\text { verbal contact }\end{array}$ & $2 \%$ & $0 \%$ & $2 \%$ & $19 \%$ & $0 \%$ & $5 \%$ \\
\hline Write report & $0 \%$ & $0 \%$ & $0 \%$ & $8 \%$ & $0 \%$ & $2 \%$ \\
\hline Originate note, letter, memo & $26 \%$ & $35 \%$ & $24 \%$ & $8 \%$ & $3 \%$ & $19 \%$ \\
\hline Originate miscellaneous & $46 \%$ & $24 \%$ & $28 \%$ & $0 \%$ & $63 \%$ & $32 \%$ \\
\hline Forward to non-subordinate & $0 \%$ & $6 \%$ & $0 \%$ & $0 \%$ & $0 \%$ & $1 \%$ \\
\hline
\end{tabular}


TABLE $X$

ANALYSIS OF THE CONTACT RECORD

\begin{tabular}{lllllll}
\hline \hline Category & AP 1 & AP 2 & AP 3 & AP 4 & AP 5 Composite \\
\hline \multicolumn{7}{c}{ Contact Totals } \\
\hline Total time in verbal & 2334 & 2018 & 1429 & 1227 & 1675 & 8683 \\
contact & min & min & min & min & min & min \\
Total number of verbal & 338 & 185 & 226 & 131 & 221 & 1101 \\
contacts & & & & & & \\
\hline
\end{tabular}

Media: Percent of Contacts/Percent of Time

\begin{tabular}{|c|c|c|c|c|c|c|}
\hline $\begin{array}{l}\text { Telephone calls } \\
\text { Scheduled meetings } \\
\text { Unscheduled meetings } \\
\text { Tours }\end{array}$ & $\begin{array}{l}30 \% / 10 \% \\
3 \% / 12 \% \\
47 \% / 32 \% \\
21 \% / 45 \%\end{array}$ & $\begin{array}{l}26 \% / 4 \% \\
10 \% / 40 \% \\
38 \% / 11 \% \\
26 \% / 45 \%\end{array}$ & $\begin{array}{l}27 \% / 9 \% \\
8 \% / 32 \% \\
44 \% / 30 \% \\
27 \% / 29 \%\end{array}$ & $\begin{array}{l}25 \% / 6 \% \\
11 \% / 47 \% \\
40 \% / 25 \% \\
24 \% / 22 \%\end{array}$ & $\begin{array}{l}73 \% / 3 \% \\
3 \% / 15 \% \\
49 \% / 40 \% \\
35 \% / 43 \%\end{array}$ & $\begin{array}{r}25 \% / 7 \% \\
6 \% / 27 \% \\
44 \% / 27 \% \\
25 \% / 39 \%\end{array}$ \\
\hline
\end{tabular}

Size of: Scheduled Meetings, Unscheduled Meetings, Tours

\begin{tabular}{lrrrrrr}
\hline Percent with 2 people & $58 \%$ & $51 \%$ & $71 \%$ & $62 \%$ & $50 \%$ & $58 \%$ \\
Percent with 3 people & $16 \%$ & $11 \%$ & $12 \%$ & $11 \%$ & $23 \%$ & $15 \%$ \\
Percent with 4 people & $4 \%$ & $4 \%$ & $5 \%$ & $3 \%$ & $7 \%$ & $5 \%$ \\
Percent with more than & $22 \%$ & $34 \%$ & $12 \%$ & $23 \%$ & $19 \%$ & $22 \%$ \\
$\quad 4$ people & & & & & & \\
\hline
\end{tabular}

Participants: Adjusted Percent of Contacts/Adjusted Percent of Time

\begin{tabular}{lcccccc}
\hline External board & $0 \% / 0 \%$ & $1 \% / 3 \%$ & $0 \% / 0 \%$ & $1 \% / 4 \%$ & $0 \% / 0 \%$ & $0 \% / 1 \%$ \\
Director & $0 \% / 0 \%$ & $0 \% / 0 \%$ & $0 \% / 0 \%$ & $1 \% / 4 \%$ & $0 \% / 0 \%$ & $0 \% / 0 \%$ \\
District support & $9 \% / 10 \%$ & $6 \% / 5 \%$ & $2 \% / 2 \%$ & $3 \% / 6 \%$ & $4 \% / 9 \%$ & $5 \% / 7 \%$ \\
Superior & $4 \% / 5 \%$ & $5 \% / 8 \%$ & $6 \% / 14 \%$ & $6 \% / 6 \%$ & $4 \% / 7 \%$ & $5 \% / 8 \%$ \\
Subordinate A & $37 \% / 30 \%$ & $47 \% / 29 \%$ & $54 \% / 36 \%$ & $67 \% / 44 \%$ & $52 \% / 38 \%$ & $49 \% / 34 \%$ \\
Subordinate B & $4 \% / 3 \%$ & $4 \% / 1 \%$ & $1 \% / 1 \%$ & $3 \% / 0 \%$ & $2 \% / 5 \%$ & $3 \% / 2 \%$ \\
Peer A & $8 \% / 10 \%$ & $7 \% / 13 \%$ & $8 \% / 13 \%$ & $8 \% / 6 \%$ & $3 \% / 7 \%$ & $7 \% / 10 \%$ \\
Peer B & $0 \% / 7 \%$ & $1 \% / 3 \%$ & $0 \% / 1 \%$ & $1 \% / 4 \%$ & $0 \% / 4 \%$ & $0 \% / 3 \%$ \\
Peer C & $0 \% / 0 \%$ & $0 \% / 0 \%$ & $0 \% / 0 \%$ & $0 \% / 0 \%$ & $0 \% / 0 \%$ & $0 \% / 0 \%$ \\
C1ient & $37 \% / 28 \%$ & $20 \% / 21 \%$ & $23 \% / 18 \%$ & $9 \% / 17 \%$ & $34 \% / 29 \%$ & $26 \% / 23 \%$ \\
Trade organization & $0 \% / 0 \%$ & $0 \% / 0 \%$ & $0 \% / 0 \%$ & $0 \% / 0 \%$ & $0 \% / 0 \%$ & $0 \% / 0 \%$ \\
Supp ier or associate & $1 \% / 2 \%$ & $2 \% / 2 \%$ & $3 \% / 5 \%$ & $1 \% / 6 \%$ & $0 \% / 0 \%$ & $2 \% / 3 \%$ \\
Pub7isher & $0 \% / 0 \%$ & $0 \% / 0 \%$ & $0 \% / 0 \%$ & $0 \% / 0 \%$ & $0 \% / 0 \%$ & $0 \% / 0 \%$ \\
Government & $2 \% / 3 \%$ & $1 \% / 7 \%$ & $1 \% / 4 \%$ & $0 \% / 0 \%$ & $0 \% / 0 \%$ & $1 \% / 2 \%$ \\
Independent & $3 \% / 9 \%$ & $5 \% / 12 \%$ & $2 \% / 5 \%$ & $1 \% / 3 \%$ & $1 \% / 1 \%$ & $3 \% / 7 \%$ \\
\hline
\end{tabular}

Form of Initiation: Percent of Total Contacts

\begin{tabular}{lrrrrrr}
\hline AP & $58 \%$ & $54 \%$ & $52 \%$ & $50 \%$ & $52 \%$ & $54 \%$ \\
Contact & $40 \%$ & $47 \%$ & $47 \%$ & $49 \%$ & $43 \%$ & $43 \%$ \\
Mutual & $2 \%$ & $3 \%$ & $0 \%$ & $1 \%$ & $4 \%$ & $2 \%$ \\
Clock & $0 \%$ & $3 \%$ & $0 \%$ & $1 \%$ & $1 \%$ & $7 \%$ \\
\hline
\end{tabular}


TABLE X (continued)

\begin{tabular}{|c|c|c|c|c|c|c|}
\hline ategory & AP 1 & AP 2 & AP 3 & AP 4 & AP 5 Cor & mposite \\
\hline \multicolumn{7}{|c|}{ Location: Percent of Contacts/Percent of Time } \\
\hline $\begin{array}{l}\text { erior's office } \\
\text { ager's office } \\
\text { 's office } \\
\text { ice of subordinate } \\
\text { l, plant, or } \\
\text { counds }\end{array}$ & $\begin{array}{c}1 \% / 0 \% \\
59 \% / 42 \% \\
0 \% / 0 \% \\
18 \% / 22 \% \\
23 \% / 44 \%\end{array}$ & $\begin{array}{c}2 \% / 8 \% \\
52 \% / 23 \% \\
1 \% / 1 \% \\
29 \% / 29 \% \\
25 \% / 46 \%\end{array}$ & $\begin{array}{r}3 \% / 15 \% \\
73 \% / 47 \% \\
1 \% / 1 \% \\
15 \% / 12 \% \\
10 \% / 11 \%\end{array}$ & $\begin{array}{c}0 \% / 0 \% \\
57 \% / 36 \% \\
2 \% / 3 \% \\
37 \% / 55 \% \\
7 \% / 6 \%\end{array}$ & $\begin{array}{cc} & 1 \% / 2 \% \\
\% \quad 67 \% / 46 \% \\
0 \% / 0 \% \\
\% \quad 22 \% / 18 \% \\
16 \% / 33 \%\end{array}$ & $\begin{array}{c}1 \% / 5 \% \\
62 \% / 38 \% \\
1 \% / 1 \% \\
22 \% / 26 \% \\
19 \% / 32 \%\end{array}$ \\
\hline $\begin{array}{l}\text { I sewhere in district } \\
\text { onference or board } \\
\text { room }\end{array}$ & $\begin{array}{l}1 \% / 2 \% \\
1 \% / 4 \%\end{array}$ & $\begin{array}{l}1 \% / 6 \% \\
0 \% / 0 \%\end{array}$ & $\begin{array}{l}1 \% / 4 \% \\
0 \% / 0 \%\end{array}$ & $\begin{array}{l}0 \% / 0 \% \\
0 \% / 0 \%\end{array}$ & $\begin{array}{l}0 \% / 9 \% \\
1 \% / 72 \%\end{array}$ & $\begin{array}{l}1 \% / 4 \% \\
0 \% / 3 \%\end{array}$ \\
\hline $\begin{array}{l}\text { vmunity } \\
\text { vay from organization }\end{array}$ & $\begin{array}{l}2 \% / 10 \% \\
0 \% / 0 \%\end{array}$ & $\begin{array}{l}2 \% / 14 \% \\
0 \% / 0 \%\end{array}$ & $\begin{array}{l}2 \% / 15 \% \\
0 \% / 0 \%\end{array}$ & $\begin{array}{l}1 \% / 7 \% \\
0 \% / 0 \%\end{array}$ & $\begin{array}{l}0 \% / 0 \% \\
0 \% / 0 \%\end{array}$ & $\begin{array}{l}1 \% / 9 \% \\
0 \% / 0 \%\end{array}$ \\
\hline \multicolumn{7}{|c|}{ Purpose of Contact: } \\
\hline $\begin{array}{l}\text { heduling } \\
\text { remony } \\
\text { ternal board work } \\
\text { Total secondary } \\
\text { atus requests and } \\
\text { solicitations }\end{array}$ & $\begin{array}{l}1 \% / 1 \% \\
3 \% / 2 \% \\
2 \% / 1 \%\end{array}$ & $\begin{array}{l}\frac{1 \%}{9} \% \\
\%\end{array}$ & $\begin{array}{l}0 \% / 0 \% \\
2 \% / 1 \% \\
6 \% / 2 \%\end{array}$ & $\begin{array}{l}2 \% / 1 \% \\
0 \% / 0 \% \\
1 \% / 1 \% \\
3 \% / 2 \% \\
1 \% / 0 \%\end{array}$ & $\begin{array}{l}1 \% / 0 \% \\
0 \% / 0 \% \\
0 \% / 0 \% \\
1 \% / 0 \% \\
0 \% / 0 \%\end{array}$ & $\begin{array}{l}2 \% / 7 \% \\
0 \% / 2 \% \\
1 \% / 2 \% \\
3 \% / 5 \% \\
3 \% / 7 \%\end{array}$ \\
\hline $\begin{array}{l}\text { tion reques } \\
\text { lager reque }\end{array}$ & $\begin{array}{l}3 \% / 1 \% \\
9 \% / 2 \%\end{array}$ & & & & $\begin{array}{l}6 \% / 1 \% \\
1 \% / 0 \%\end{array}$ & $\begin{array}{l}3 \% / 7 \% \\
9 \% / 2 \%\end{array}$ \\
\hline and & $4 \% 1$ & 15 & 2 & $13 \%$ & $7 \% / 7 \%$ & a \\
\hline $\begin{array}{l}\text { on exchange } \\
\text { onal and } \\
\text { ational tours }\end{array}$ & $\begin{array}{r}9 \% / 10 \% \\
20 \% / 45 \%\end{array}$ & $\begin{array}{l}5 \% / \\
26 \% 1\end{array}$ & $\begin{array}{l}11 \% \\
27 \%\end{array}$ & $\begin{array}{l}11 \% / 17 \% \\
24 \% / 22 \%\end{array}$ & $\begin{array}{l}\% \quad 8 \% / 12 \% \\
\% 35 \% / 43 \%\end{array}$ & $\begin{array}{r}9 \% / 10 \% \\
25 \% / 39 \%\end{array}$ \\
\hline $\begin{array}{l}\text { ving information } \\
g \text { information }\end{array}$ & $\begin{array}{l}19 \% / 12 \% \\
20 \% / 8 \%\end{array}$ & & & & & \\
\hline informational & $\begin{array}{l}1 \% / 1 \\
69 \% /\end{array}$ & $\begin{array}{r}4 \% \\
77 \%\end{array}$ & $\begin{array}{r}1 \% \\
66 \%\end{array}$ & $\begin{array}{r}1 \% \\
84 \%\end{array}$ & $\begin{array}{r}2 \% / 13 \% \\
\% 80 \% / 82 \%\end{array}$ & $\begin{array}{l}2 \% / 9 \% \\
4 \% / 79 \%\end{array}$ \\
\hline & $\begin{array}{l}3 \% 1 \\
0 \% 1\end{array}$ & $\begin{array}{l}1 \% \\
1 \%\end{array}$ & & $\begin{array}{l}3 \% \\
1 \%\end{array}$ & $\begin{array}{l}0 \% / 1 \% \\
0 \% / 1 \%\end{array}$ & $\begin{array}{l}2 \% / 4 \% \\
0 \% / 7 \%\end{array}$ \\
\hline decision- & & & U & $4 \%$ & $0 \% / 2 \%$ & $2 \% / 5 \%$ \\
\hline a & & & & & & \\
\hline $\begin{array}{l}\text { ing/Discipline } \\
\text { ne }\end{array}$ & & & & & & \\
\hline $\begin{array}{l}\text { Total Counseling/ } \\
\text { Discipl ine }\end{array}$ & $1 \% / 16 \%$ & 10 & $\% / 71 \%$ & $0 \% / 0 \%$ & $14 \% / 16 \%$ & $8 \% / 10 \%$ \\
\hline
\end{tabular}


Participants In Interactions

The composite figures of the sender, target, and participant elements of these tables directly address the first aspect of the research subproblem--with whom an assistant principal interacts. Table XI isolates and combines those three categories from the three more comprehensive tables. The participant categories were the most difficult to analyze, because contacts frequently involved more than one participant group. The data analysis was further complicated by the fact that the possible combinations were so numerous that analyzing combined categories did not seem feasible. Therefore, the researcher calculated two percentages for participant "percent of contacts" and "percent of time." The method employed by Mintzberg (1973) was used to ascertain these percentages for each assistant principal's Contact Record (Appendix F). Under this method, the number of contacts an assistant principal had with each participant group was tallied and divided by the total number of verbal contacts. In a like manner, the total amount of time with each participant group was totaled and divided by total time in verbal contacts. Since more than one participant group could be involved in a single contact, both the total "percent of contacts" and "percent of time" figures exceeded 100 percent. Therefore, adjusted percentages were also calculated. Under this second system, the total percentage figures equaled 100 percent. This was achieved by changing denominators: from number of contacts to number of participant groups in contacts; from amount of time in verbal contacts to a figure reflecting compounded time (e.g., if three participant groups were involved in a three-minute contact, each 
participant group was assigned three minutes). The "adjusted contact" and "adjusted time" percentages were used for the composite table (Table X).

TABLE XI

THE ASSISTANT PRINCIPAL'S INTERACTIONS: SENDER/TARGET OF WRITTEN COMMUNICATIONS AND PARTICIPANTS IN VERBAL CONTACTS

\begin{tabular}{|c|c|c|c|c|}
\hline Participant & $\begin{array}{c}\text { Mail } \\
\text { Senders }\end{array}$ & $\begin{array}{c}\text { Mail } \\
\text { Targets }\end{array}$ & $\begin{array}{r}\text { Verbal } \\
\text { Partic } \\
\text { Adjusted } \\
\text { Contacts }\end{array}$ & $\begin{array}{l}\text { Contact } \\
\text { pants } \\
\frac{\text { Adjusted }}{\text { Time }}\end{array}$ \\
\hline External board & $1 \%$ & $1 \%$ & $0 \%$ & $7 \%$ \\
\hline Director & $0 \%$ & $0 \%$ & $0 \%$ & $0 \%$ \\
\hline District support & $8 \%$ & $3 \%$ & $5 \%$ & $7 \%$ \\
\hline Superior & $9 \%$ & $3 \%$ & $5 \%$ & $8 \%$ \\
\hline Subordinate $A$ & $64 \%$ & $79 \%$ & $49 \%$ & $34 \%$ \\
\hline Subordinate $B$ & $0 \%$ & $2 \%$ & $3 \%$ & $2 \%$ \\
\hline Peer A & $2 \%$ & $2 \%$ & $7 \%$ & $10 \%$ \\
\hline Peer 8 & $1 \%$ & $1 \%$ & $0 \%$ & $3 \%$ \\
\hline Peer C & $0 \%$ & $0 \%$ & $0 \%$ & $0 \%$ \\
\hline client & $4 \%$ & $10 \%$ & $26 \%$ & $23 \%$ \\
\hline Trade organization & $6 \%$ & $1 \%$ & $0 \%$ & $0 \%$ \\
\hline \multirow{5}{*}{$\begin{array}{l}\text { Supplier or } \\
\text { associate } \\
\text { Publisher } \\
\text { Government } \\
\text { Independent }\end{array}$} & & & & \\
\hline & $3 \%$ & $7 \%$ & $2 \%$ & $3 \%$ \\
\hline & $0 \%$ & $0 \%$ & $0 \%$ & $0 \%$ \\
\hline & $1 \%$ & $0 \%$ & $7 \%$ & $2 \%$ \\
\hline & $1 \%$ & $1 \%$ & $3 \%$ & $7 \%$ \\
\hline
\end{tabular}

Mintzberg (1973) stated, "Subordinates generally consume one-third to one-half of the manager's contact time" (p. 53). Like the chief executives, the assistant principals were consistently involved with subordinates. The assistant principal's subordinates with in the high school (subordinate A) sent 64 percent of the incoming mail, were the targets of 79 percent of the outgoing correspondence, and were involved in nearly half (49\%) of the assistant principal's verbal contacts and 
one-third (34\%) of contact time. The client group, consisting of students and students' family members, ranks second overall as a category of people with whom an assistant principal frequently communicated; however, the results are not as consistent across mail and verbal contact categories. Clients sent and received four percent and 10 percent respectively of the assistant principal's mail, but were involved in 26 percent of the assistant principal's total contacts to which 23 percent of verbal contact time was devoted. Since so much of the assistant principal's communication focused on clients and subordinates, all other sender, target, and participant contacts categories naturally account for markedly less mail and verbal contacts. The assistant principals were clearly involved with their organizational subordinates and the young people and adults the organization is designed to serve.

Mintzberg (1973) determined, in his study of executives, that, "The manager may be likened to the neck of an hourglass, standing between his own organization and a network of outside contacts, linking them in a variety of ways" (p. 52). He said, in fact, "External contacts generally consume one-third to one-half of the manager's contact time" (p. 52). Table XII details the division of the assistant principal's external and internal contacts, in terms of proportions of contact time. The assistant principal did spend approximately one-third (36\%) of verbal contact time with people external to the organization. The following sample contacts illustrate the variety of interactions which assistant principals had with people external to the organization. One assistant principal went to a morning Rotary board meeting (external board). Another conducted a special education staff meeting at which a student and her parents 
were present (client). A vice-principal telephoned a local university professor to request her assistance with conference planning (supplier or associate). A breakfast meeting attended by a third assistant principal was held to discuss local teenage "cruising" and loitering problems; one of the meeting participants was a city commissioner (government). At various athletic contests, assistants conversed with alumni and faculty spouses (independent).

TABLE XII

THE ASSISTANT PRINCIPAL'S CONTACT TIME WITH PARTICIPANTS EXTERNAL TO AND INTERNAL TO THE ORGANIZATION

Contacts

Adjusted Contact Time (\%)

External

External Board

Client

Supplier or associate

Government

Independent

Sub Total

$\begin{array}{r}1 \\ 23 \\ 3 \\ 2 \\ 7 \\ \hline 36\end{array}$

Internal

District support personnel

Superior

Subordinate $A$

Subordinate $B$

Peer A

Peer B

Sub Total

$\begin{array}{r}7 \\ 8 \\ 34 \\ 2 \\ 10 \\ 3 \\ \hline 64\end{array}$

In a like manner, 36 percent of the assistant principals total

verbal contact time involved participants from outside the school district, however, the majority of time $(64 \%)$ was spent with internal per- 
sonnel: clerical, professional, support, and administrative. It should be noted also that under the Mintzberg system of participant categorization, students are classified as clients and, thus, external to the formal organization, although they are clearly an irreplaceable element in a school's daily operations. The highest proportion of external contact time (23 percent devoted to student and parent clients) indicates that even when verbal contact time is spent with persons external to the district, the distance from the organization is not very great.

Mintzberg (1973) concluded that, "The manager spends relatively little time with his superior...generally on the order of 10 percent" (p. 53). The results for the assistant principal are rather parallel. Though the composite of assistant principals spent a great deal of time with personnel internal to the district, little of this time (8\%) was spent with superiors. The superior category also accounts for only nine percent of input mail, three percent of output mail, and five percent of total contacts. The interactions with the principal are, in fact, even more limited than these percentages indicate, as the superior categorization also includes communications with area and central office superiors. Given the minimal written communications, contacts and time directly communicating with superiors, there is reason to question whether principals and their assistants exhibit the bonds of personal intimacy found between other "assistants-to" and their superiors (Whistler, 1960). Principals and assistant principals may have divided administrative responsibilities to such an extent that frequent interaactions do nct or cannot occur. Except for interaction in the infrequent formal meetings--administrative staff meetings, faculty meetings, hearings--the communications between principal and assistant appeared to depend on chance. They happened to arrive in the lunch room at the same 
time or encountered one another while on tour. As a result, it is questionable that a warm personal relationship results as it does between superiors and assistants who are more frequently together.

Only three sender, target, participant categories revealed no assistant principal involvement, those categories being director, peer $C$ (outside the organization), and publisher; and it would be more real istic to assume that these percentage figures were more a product of the restricted observation time than they are a reflection of a year's contacts. In fact, assistant principals spoke as if they were quite knowledgeable about individual school board members and about the board's evolution over recent years; also, most sample members were active in state and national professional organizations, whose memberships would include peers outside of the district.

Although communications are heaviest in the client and subordinate categories, the assistant principal, then, does communicate at least to some small degree with a number of audiences, many specifically named by interviewees--students, community people, teachers, coaches, court workers, parents, business-people, and other administrators. Fairly frequently, in fact, dual or multiple audiences were involved in a single activity, as mentioned previously and illustrated in Table XIII. A single contact--a scheduled meeting attended by Assistant Principal \#5--illustrates the phenomenon of multiple participant groups involved in a contact. The meeting was held at the central office and was for the purpose of reviewing various elements of the district's counseling program. Participants included other high school assistant principals (Peer B); teachers from other schools (Subordinate B); district staff in counseling, bilingual/ English-as-a-second-Language, and counseling programs (district support). 
TABLE XIII

NUMBERS OF PARTICIPANT GROUPS INVOLVED IN THE ASSISTANT PRINCIPAL'S SCHEDULED MEETINGS, UNSCHEDULED MEETINGS, AND TOURS

\begin{tabular}{llrrrrr}
\hline & \multicolumn{8}{c}{ Number } & of & Participant Groups \\
\cline { 2 - 7 } Activity & 1 & 2 & 3 & 4 & 5 & 6 \\
\hline Scheduled meetings & $47 \%$ & $26 \%$ & $18 \%$ & $6 \%$ & $1 \%$ & $1 \%$ \\
Unscheduled meetings & $38 \%$ & $10 \%$ & $1 \%$ & $1 \%$ & $0 \%$ & $0 \%$ \\
Tours & $42 \%$ & $35 \%$ & $15 \%$ & $4 \%$ & $4 \%$ & $0 \%$ \\
\hline
\end{tabular}

Perhaps for the investigator attempting to record the activities of assistant principals, the most striking aspect of the communications was the number of people with whom an assistant interacts daily. For each verbal contact, the investigator recorded the number of participants. Table XIV indicates the total number of participants involved in all the contacts of each assistant principal's five observed workdays. Those numbers naturally include some people who are counted more than once. However, the figures--ranging from 530 people to 1438 people in an assistant principal's five days of observation--do provide some tentative indication of the large number of people with whom an assistant principal was involved. Using the figure for the composite of assistant principals, the average assistant principal interacted with 929 people per work week (or 186 people per day). These data illuminate the extent to which work is verbal and people-oriented. 
TABLE XIV

TOTAL NUMBERS OF PARTICIPANTS INVOLVED

IN THE ASSISTANT PRINCIPAL'S

VERBAL CONTACTS

\begin{tabular}{lllllll}
\hline Category & AP 1 & AP 2 & AP 3 & AP 4 & AP 5 & Composite \\
\hline $\begin{array}{l}\text { Total Number of } \\
\text { Participants } \\
\text { (5 days of observation) }\end{array}$ & 1373 & 1438 & 627 & 530 & 675 & 4643 \\
\hline
\end{tabular}

Means of Interactions

The second focus of the research subproblem regarding the assistant principar's interactions was means: how does the assistant principal communicate? Mintzberg (1973) described the chief executives' methods of communication as follows:

Verbal and written contacts are the manager's work and his prime tools are five media--mail (documented), telephone (purely verbal), unscheduled meetings (informal face-to-face), scheduled meetings (formal face-to-face), and tour (observational). The manager clearly favors the three verbal media, spending most of his time in verbal contact. (p. 52)

As previously detailed in the Chronology Record analysis, the assistant principals' time was apportioned as follows: desk work, 17 percent; telephone calls, six percent; scheduled and unscheduled meetings, 24 percent each; and tours, 34 percent. Thus, the majority (54\%) of the assistant principal's work time was also devoted to the three ver: bal media--scheduled and unscheduled meetings and telephone calls. The dominance of verbal media is reemphasized by an analysis of the assistant principals' Contact Records. Twenty-five percent of the contacts were telephone calls; six percent were scheduled meetings; and forty-four percent, unscheduled meetings. As a result, a total of 75 percent of all 
contacts employed verbal media. In addition, tours, which involved another 34 percent of the assistant principal's time, cannot be viewed as strictly observational. The assistant principals, while touring, encountered and verbally communicated with many individuals, as Table XV documents. In fact, as this table indicates, on 22 percent of the tours, the assistant principal interacted with in excess of 10 people per tour. To illustrate, on one eight minute tour of the student cafeteria, halls, classrooms, and grounds, Assistant Principal \#2 conversed with 12 students, an aide, and the school's Activities Director. Table XV also reveals the emphasis on dyadic interactions. With the exception of the tour, the assistant principals' verbal communications cluster in the twoperson category.

TABLE XV

SIZE OF THE ASSISTANT PRINCIPAL'S MEETINGS AND TOURS

\begin{tabular}{|c|c|c|c|c|c|c|c|c|c|}
\hline \multirow[b]{2}{*}{ Activity } & \multicolumn{9}{|c|}{ Number of People Involved } \\
\hline & 2 & 3 & $4-10$ & $11-20$ & $21-30$ & $31-40$ & $47-50$ & $50+$ & Total \\
\hline $\begin{array}{l}\text { Scheduled } \\
\text { meetings }\end{array}$ & $39 \%$ & $10 \%$ & $30 \%$ & $8 \%$ & $3 \%$ & $3 \%$ & $0 \%$ & $7 \%$ & $100 \%$ \\
\hline $\begin{array}{l}\text { Unscheduled } \\
\text { meetings }\end{array}$ & $82 \%$ & $13 \%$ & $4 \%$ & $0 \%$ & $0 \%$ & $0 \%$ & $0 \%$ & $0 \%$ & $99 \%$ \\
\hline Tours & $22 \%$ & $20 \%$ & $36 \%$ & $14 \%$ & $4 \%$ & $2 \%$ & $1 \%$ & $1 \%$ & $100 \%$ \\
\hline $\begin{array}{l}\text { Al1 three } \\
\text { combined }\end{array}$ & $58 \%$ & $15 \%$ & $17 \%$ & $6 \%$ & $2 \%$ & $1 \%$ & $0 \%$ & $1 \%$ & $100 \%$ \\
\hline
\end{tabular}


The remaining activity category--desk work--deserves special attention. Though desk work accounted for only 17 percent of the assistant principal's time, an analysis of the mail does reveal additional information regarding how the assistant principal communicated. Relative to chief executives' mail processing, Mintzberg (1973) concluded, "Mail receives cursory treatment, al though it must be processed regularly" (p. 52) and, "The manager generates much less mail than he receives" ( $p$. 52).

The former statement needs to be modified in order to accurately reflect the assistant principal's treatment of mail. Individual assistant principals did use between three and 11 daily desk sessions to regularly review and initiate correpondence. One assistant principal alluded to the persistent need to deal with the mail, saying, "A constant job of every administrator is getting rid of paper." A1so, the majority (59\%) of input was given minimal attention, as Table VIII documented: 35 percent was simply given a glance; 24 percent was skimmed. However, another 40 percent was read at a normal pace, indicating that a substantial portion of correspondence is given more than the "cursory treatment" Mintzberg described (p. 52). Consistent with Mintzberg's chief executives, more mail is received than is initiated, as indicated by Table XVI, in which various elements of the mail records of assistant principals are drawn together. Compiling the results of 25 days of observation for the composite sample, the "output as percent of input" figure is less than one-half (46\%). This may be due, in part, to the highest proportion (41\%) of input mail being reference data, such as a set of minutes, which necessitated review and filing but not a written 
response. Regardless of the reasons for more receipt than initiation of mail, it is clear that assistant principals were more often communicated with than communicating when the written word was the basis for interaction.

TABLE XVI

THE ASSISTANT PRINCIPAL'S MAIL:

RECEIPT AND INITIATION

\begin{tabular}{lcccccc}
\hline & AP 1 & AP 2 & AP 3 & AP 4 & AP 5 & Composite \\
\hline $\begin{array}{l}\text { Number of pieces } \\
\text { received }\end{array}$ & 80 & 49 & 103 & 113 & 54 & 399 \\
$\begin{array}{l}\text { Total output } \\
\begin{array}{l}\text { Number of } \\
\text { reactions to inputs }\end{array}\end{array}$ & 46 & 17 & 50 & 37 & 32 & 182 \\
$\begin{array}{l}\text { Number self- } \\
\text { initiated }\end{array}$ & 28 & 8 & 19 & 12 & 20 & 87 \\
$\begin{array}{l}\text { Output as percent } \\
\text { of input }\end{array}$ & $58 \%$ & $35 \%$ & $49 \%$ & $33 \%$ & $59 \%$ & $46 \%$ \\
\hline
\end{tabular}

Many people would contend that forms, forms, and more forms are a symbol of modern bureaucratic institutions. The urban district is certainly not an exception to this observation if the mail of urban assistant principals is indicative of the district's total correspondence. Many forms are directed to the assistant principals, and assistant principals send out numerous forms. There were purchase order forms, forms for daily bulletin notices, forms to admit late students to their classes, referral forms for describing student misbehavior, forms to request check authorizations or the scheduling of events on the building calendar or student transfers to another high school building. In 
fact, the highest proportion of both mail input (34\%) and mail output (53\%) was by some type of form.

\section{Purpose of Interactions}

The final consideration relative to the communications of assistant principals is what Mintzberg (1973) termed purpose. Why do the vice-principal's interactions take place? Assistant principals gave numerous reasons for their interactions, of which the following are illustrative:

- "Basically they all want something."

- "Wherever there are problems, the administrative V.P. is interacting."

- "If I had to sum it al1 up, my interactions are to keep school going in the best possible way."

- "[Interactions are for making] ...decisions."

- "[Interactions are] in regard to student perfo inance and conduct."

- "[The assistant principal interacts with people] wishing to sell you something, wishing to promote a cause, assisting you with some decisions."

The results of the investigator's actual observations of desk work and verbal contacts, and the resulting mail and contact purpose categorizations, are presented in Tables XVII and XVIII. 
TABLE XVII

PURPOSES FOR THE ASSISTANT PRINCIPAL'S

WRITTEN COMMUNICATIONS

\begin{tabular}{|c|c|}
\hline Purpose & Percent \\
\hline \multicolumn{2}{|l|}{ Input Mail } \\
\hline Total requests & 34 \\
\hline $\begin{array}{l}\text { Acknowl edgments } \\
\text { Status requests } \\
\text { Solicitations } \\
\text { Authority requests }\end{array}$ & $\begin{array}{r}3 \\
3 \\
8 \\
20\end{array}$ \\
\hline Total informational & 66 \\
\hline $\begin{array}{l}\text { Reference data } \\
\text { General reports } \\
\text { Periodical news } \\
\text { Events } \\
\text { Reports on operations } \\
\text { Advice on situations } \\
\text { Problems and pressures } \\
\text { Ideas }\end{array}$ & $\begin{array}{r}41 \\
2 \\
8 \\
5 \\
1 \\
1 \\
9 \\
1\end{array}$ \\
\hline \multicolumn{2}{|l|}{ Output Mail } \\
\hline $\begin{array}{l}\text { Acknowledge input } \\
\text { Write to third party } \\
\text { Reply to information received } \\
\text { Forward information to subordinate } \\
\text { Reply to written request } \\
\text { Forward request to subordinate } \\
\text { Acknowledge or reply to verbal contact } \\
\text { Write report } \\
\text { Originate note, letter, or memo } \\
\text { Originate miscellaneous } \\
\text { Forward to non-subordinate }\end{array}$ & $\begin{array}{r}0 \\
0 \\
9 \\
10 \\
15 \\
7 \\
5 \\
2 \\
19 \\
32 \\
1\end{array}$ \\
\hline
\end{tabular}


TABLE XVIII

PURPOSES FOR THE ASSISTANT PRINCIPAL'S

VERBAL CONTACTS

\begin{tabular}{|c|c|c|}
\hline Purpose & $\begin{array}{c}\text { Adjusted } \\
\text { Contact Percent }\end{array}$ & $\begin{array}{l}\text { Adjusted } \\
\text { Time Percent }\end{array}$ \\
\hline \multicolumn{3}{|c|}{ Secondary } \\
\hline $\begin{array}{l}\text { Schedul ing } \\
\text { Ceremony } \\
\text { External board work }\end{array}$ & $\begin{array}{l}2 \\
0 \\
1\end{array}$ & $\begin{array}{l}1 \\
2 \\
2\end{array}$ \\
\hline \multicolumn{3}{|c|}{ Requests and Solicitations } \\
\hline $\begin{array}{l}\text { Status requests and solicitations } \\
\text { Action requests } \\
\text { Manager requests }\end{array}$ & $\begin{array}{l}3 \\
3 \\
9\end{array}$ & $\begin{array}{l}1 \\
1 \\
2\end{array}$ \\
\hline \multicolumn{3}{|c|}{ Informational Contacts } \\
\hline $\begin{array}{l}\text { Information exchange } \\
\text { Observational and informational tours } \\
\text { Receiving information } \\
\text { Giving information } \\
\text { Review }\end{array}$ & $\begin{array}{r}9 \\
25 \\
20 \\
18 \\
2\end{array}$ & $\begin{array}{r}10 \\
39 \\
12 \\
9 \\
9\end{array}$ \\
\hline \multicolumn{3}{|c|}{ Decision-Making } \\
\hline $\begin{array}{l}\text { Strategy } \\
\text { Negotiation }\end{array}$ & $\begin{array}{l}2 \\
0\end{array}$ & $\begin{array}{l}4 \\
1\end{array}$ \\
\hline \multicolumn{3}{|c|}{ Counseling/Discipline } \\
\hline $\begin{array}{l}\text { Counseling } \\
\text { Discipline } \\
\text { Counseling/Discipline }\end{array}$ & $\begin{array}{l}2 \\
3 \\
3\end{array}$ & $\begin{array}{l}3 \\
3 \\
4\end{array}$ \\
\hline
\end{tabular}

Data indicate that the assistant principal's input mail is predominately (66\%) informational, with the highest proportion (41\%) of all mail being simply reference data. The remaining 34 percent of the mail received by the assistant principals is classified into various types of requests with the second highest input mail category the 20 percent categorized specifically as authority requests. 
As for mail output, more than half $(51 \%)$ is accounted for by a combination of pieces of mail originated by the assistant principar. The vice-principals initiated notes, letters, and memos (32 percent of total mail output); another 19 percent was miscellaneous pieces of output-often forms. The only other output category exceeding 10 percent is that of replies to the written requests $(15 \%)$.

The assistant principal's verbal contacts were for participation in ceremonia? occasions, scheduling events, responding to and initiating requests, developing strategy, and disciplining students. However, of the major categorizations--total secondary, total requests and solicitations, total informationa?, and total counseling/discipline, again by far the highest proportions are in the informational category. Seventyfour percent of the assistant principal's contacts were for informational purposes, with 79 percent of contact time having been spent on informational interactions. Of further note, all individual purpose categories yielding 10 percent or more are subsumed by the total informational classification. Assistant principals can legitimately be viewed as information processors. For example, they focused nine percent of contact time to the exchange of information, nine percent of verbal time to giving information. In addition, contacts for the purpose of receiving information accounted for 12 percent of the assistant principal's contact time. Finally, the highest proportion of both contacts (25\%) and contact time (39\%) was for the observational and informational tours which were so frequently a part of the assistant principal's workday. Again, this activity is found under the total informational purpose. 
This emphasis on information processing, found in both mail and contact purpose categorizations, is consistent with the management emphasis on information transmission noted by Whistler (1960), Mintzberg (1973), and Pitner (1978). In this respect, the assistant principal is very much like the "assistant-to" studied by Whistler and described as "an extremely useful channel of information" (p. 208). They give, receive, review, and exchange information; they tour to gather and to deliver information. Though the literature indicates that assistant principals are often assigned pupil personnel tasks, particularly as related to student discipline, the observational data on this point needs exploration. Only eight percent of the composite assistant principals' contacts and 10 percent of contact time were devoted to counseling and/or discipline. This picture does not differ markedly even when the contacts of the three disciplinary vice-principals are isolated: total counseling/discipline contacts ranged from seven to 11 percent; their contact time for this purpose from 11 to 16 percent. This does not mean that these are the only contacts that involved discipline or counseling topics. Many of the contacts classified as informational dealt with matters related to student conduct. For example, one information exchange contact was a discussion of a student behavior card and a discipline policy statement. One assistant principal took an after-school observational tour, specifically because English-as-a-Second-Language teachers had alerted him to incidents of harrassment of Asian students. A contact categorized as informational tour was to gather further information regarding a student's purchase of an item on which the price tag was far under the local department store's normal sale price. When an Administrative Assistant told an assistant principal about various 
"skippers," this was classed as receiving information. When an assistant principal called a mother to tell her that her child was on probation and would be suspended for repeated nonattendance, that administrator was giving information. Finally, an assistant principal and a social worker meeting on an extensive case load of students conducted a review session. Though the content of such informational contacts often centered on negative aspects of teenagers' behaviors and could, as a result, be debilitating to the assistant principal, the point is that a minimal amount of the assistant principal's time was found to be for the direct purpose of disciplining young people. Instead, the assistant principal was primarity dealing with information transmission. In the same way that other managers' informational contacts might concern marketing, research, or financial planning topics, the assistant principals' often concerned student conduct. Though the topics may change, the underlying and general purpose--information processing--is the same.

For the most part, the marked differences that exist between the purpose results for assistant principals and those derived from Mintzbergs's (1973) study of chief executives appear to be attributable to the differences in status and authority between a chief executive and an assistant principal. Tables XIX and XX display the mail and contact categories which differ more than 10 percentage points for assistant principals and chief executives (Mintzberg, 1973, Tables 11-13, pp. 244245, p. 251). 
TABLE XIX

DISCREPANT PROPORTIONS* IN THE COMPARISON OF THE MAIL PIJRPOSE CATEGORIES FOR ASSISTANT PRINCIPALS AND MINTZBERG'S CHIEF EXECUTIVES

\begin{tabular}{|c|c|c|}
\hline Purpose & $\begin{array}{l}\text { Assistant } \\
\text { Principals }\end{array}$ & $\begin{array}{c}\text { Chief } \\
\text { Executives }\end{array}$ \\
\hline \multicolumn{3}{|l|}{ Input Mail } \\
\hline $\begin{array}{l}\text { Authority requests } \\
\text { Reference data } \\
\text { Reports on operations }\end{array}$ & $\begin{array}{r}20 \% \\
41 \% \\
1 \%\end{array}$ & $\begin{array}{r}5 \% \\
14 \% \\
18 \%\end{array}$ \\
\hline \multicolumn{3}{|l|}{ Output Mail } \\
\hline $\begin{array}{l}\text { Acknowledge input } \\
\text { Forward information to subordinates } \\
\text { Reply to written request }\end{array}$ & $\begin{array}{r}0 \% \\
10 \% \\
15 \%\end{array}$ & $\begin{array}{l}12 \% \\
23 \% \\
33 \%\end{array}$ \\
\hline \multicolumn{3}{|c|}{$\begin{array}{c}\text { *Categories for which more than a } 10 \text { percentage point } \\
\text { TABLE XX } \\
\text { DISCREPAIT PROPORTIONS* IN THE COMPARISON } \\
\text { OF THE CONTACT PURPOSE CATEGORIES FOR } \\
\text { ASSISTANT PRINCIPALS AND MINTZBERG'S } \\
\text { CHIEF EXECUTIVES }\end{array}$} \\
\hline \multirow[t]{2}{*}{ Purpose } & $\begin{array}{l}\text { Assistant } \\
\text { Principals }\end{array}$ & $\begin{array}{l}\text { Chief } \\
\text { Executives }\end{array}$ \\
\hline & & \\
\hline \multicolumn{2}{|c|}{ Contact $\% /$ Time $\%$} & Contact $\% /$ Time $\%$ \\
\hline $\begin{array}{l}\text { Scheduling } \\
\text { Ceremony } \\
\text { Action requests } \\
\text { Observational and informational tours }\end{array}$ & $\begin{array}{l}2 \% / 1 \% \\
0 \% / 2 \% \\
3 \% / 1 \% \\
25 \% / 39 \%\end{array}$ & $\begin{array}{c}15 \% / 3 \% \\
6 \% / 12 \% \\
17 \% / 12 \% \\
2 \% / 7 \%\end{array}$ \\
\hline
\end{tabular}

*Categories for which more than 10 percentage point difference exists. 
Discussion of several purpose categories illustrates the rationale for the speculation that differences in purpose results between chief executives and assistant principals may be due to job differences. Since the chief executive is titular head of an organization, perhaps it is only logical that this official would be involved in more ceremonial events, would receive both more requests for and reports on various actions, and would be more apt to forward correspondence to one of many subordinates. On the other hand, it may well be that the assistant principal is less insulated from trivia than is the chief executive, leading to the assistant principal's personal receipt of a high proportion of reference materials, often of rather minimal significance. The one category of discrepancy that is somewhat enigmatic is that of mail input authority requests. The chief executive wields the greatest line authority in the organization; the assistant principal exercises much less authority. It is not evident, then, why the assistant principal would receive a higher proportion of written authority requests than the chief administrator. It may be that as volume differs so does the nature of the content of correspondence. While the assistant principal may be asked to authorize a $\$ 200$ expenditure, the chief executive would likely be protected from such numerous and reiatively minor decisions but would more likely be approached when the expense was $\$ 20,000$.

Initiation and Reaction in the Assistant Principal's Workday

Much of the recent literature on managerial work contains a rather pessimistic view of the manager, whereby management exercises much less control over events than might be assumed. Stewart (1979) stated, 
"Managers can get through the day very busily without an explicit agenda, reacting to the people and problems that present themselves. The momentum of the job carries them along" (p. 38). Davis and Luthans (1980) made a similar observation: "The real, live manager operates in a world of distractions and disruptions produced by unexpected visits from coworkers, urgent phone calls, inflowing paperwork, and unscheduled meetings" (p. 67).

Observers of school administrators at work have reached similar conclusions. Wolcott (1973) determined that the principal was capable of exercising little leadership because of constraints such as policy from superiors, organization by professional subordinates, and the consistent need to compromise (Chap. 11). Austin and Brown (1970) observed that, "The activities of the assistant principal are to a considerable extent, unpredictable from day to day... Forecasting what the assistant principal will be involved in during the next hour or the next day is in the same class as forecasting the weather" (p. 9).

Mintzberg (1973), however, took a somewhat more moderate view:

The manager's job reflects a blend of duties and rights. Although superficial study of managers' activities suggests that they often control little of what they do, closer analysis suggests that the manager can exert self-control in two important ways. The manager is responsible for many initial commitments, which then lock him into a set of ongoing activities; and the manager can take advantage of his obligations by extracting information, by exercising leadership, and in many other ways. (p. 53)

Although Davis and Luthans commented, "Another interesting finding that has recently emerged is that managers tend to overestimate the control they have over what they do" (1980, p. 66), this did not hold true for subject assistant principals. Their comments reflect a strong belief that their jobs are essentially reactive: 
- "God, I try to be proactive, and some things like [a new discipline intervention program] are. Much too much of my energy goes out reacting."

- "On a percentage basis, I suppose reaction would be by far the greater part."

- "I think most of it's reactive."

- "In discipline it's always reactive."

- "...never know. Things could really jump till 4:00." "Could be calm, or all hell could break loose."

Some of the assistant principals in this sample indicated some difficulty with defining terms and with classifying work as reactive or proactive. The one sample member who considered his work mostly proactive stated that he assumed proactive was positive in connotation; reactive, negative. Then he went on to say, "Ninety percent of my work is proactive, I would say--planned, deliberate, has a purpose. My reacting ...just part of the job, part of any bureaucratic organization." Another maintained, "Everything is reactive." Another vice-principal had the same view: "Even the planned you do is in response to something... I think my creativeness is in orchestrating it."

Table XXI presents various structured-observation indicators of the degree of workday initiation and reaction of both assistant principals and Mintzberg's chief executives (1973, Tables 12 and 13, p. 245, p. 250). As previously established, both composite samples were found to have initiated less mail than they received. For assistant principals mail output as a percentage of mail input is slightly less than one-half $(46 \%)$; for chief executives, the figure is closer to one-third (35\%). 
Of the total mail sent by management, assistant prircipals self-initiated 48 percent; chief executives, only 11 percent. It should be noted, however, that much of assistant principals' self-initiated mail was rather routine in nature; each piece was certainly not a unique or timeconsuming communication. For example, assistant principals frequently sent out letters of rather established formats such as a communication to parents regarding a child's class withdrawal. They also filled in forms and wrote notes, classifications not recognized under Mintzberg's output mai1 purpose categories.

TABLE XXI

PROACTIVE/REACTIVE ASPECTS OF THE WORKDAYS OF ASSISTANT PRINCIPALS AND MINTZBERG'S

CHIEF EXECUTIVES

\begin{tabular}{lcc}
\hline \hline Initiation Indicator & $\begin{array}{c}\text { Assistant } \\
\text { Principals }\end{array}$ & $\begin{array}{c}\text { Chief } \\
\text { Executives }\end{array}$ \\
\hline Mail output as percent of input & 46 & 35 \\
Self-initiated mail as percent of & 48 & 11 \\
output & & \\
Initiation of Verbal Contacts & 54 & 32 \\
Manager Percentage & 43 & 57 \\
Contact Percentage & 2 & 5 \\
Mutual Percentage & 1 & 7 \\
Clock Percentage & & \\
\hline
\end{tabular}

The assistant principals initiated more than half (54\%) of their verbal contacts, indicating that in verbal communications the viceprincipal is more often proactive rather than reactive, contrary to interviewees' general perceptions. For chief executives, the results are reversed--the chief executives initiated 32 percent of their verbal contacts, but nearly 60 percent $(57 \%)$ were instead initiated by the 
opposite party. For both samples, the combined categories for initiation by mutual consent and by clock (meetings on a regular schedule) accounted for a rather smal1 proportion (3\% and $12 \%$ ) of total contacts. The higher proportion of clock initiation for chief executives is logicaliy tied to the top executives' numerous hours in scheduled meetings.

In summary, it is difficult to make any clear summary statements regarding initiation-reaction in the assistant principal's workday. Austin and Brown (1970) noted this difficulty (p. 19). Mintzberg (1973) also found managerial activities to be a blend of reactions and selfcontrolled activities (pp. 51-53), and Pitner (1978) concluded that suburban superintendents operated under constraints but could al so exercise initiative (p. 120). Clearly, managers react and they initiate; their work is not purely reactive, nor solely proactive. The main concern may be the "decision-press" that Peterson contended results from work activities that are reactive:

When tasks demand immediate attention, are unscheduled and nonroutine in nature, and are initiated by a variety of different people the careful coordination and planning of time and energy will be particularly difficult.... Second, frustration can develop if the individual feels controlled by the job rather than in control of it. (p. 2)

\section{Differences in the Workdays of Assistant Principais}

Assistant principals were asked whether they perceived their workdays to be similar to or different from other urban high school assistant principals. Respondents used almost the same words to state that they saw the daily work of their peers as very similar to their own. An analysis of the four basic tables delineating major aspects of the 
Chronology, Communication, and Contact Records (Table IV, VIII, IX, and $x$ ) indicates that the assistant principals' contentions of workday similarity are to some degree accurate, but also somewhat overstated.

Assistant principals are quite similar in some respects. For example, their days were all centered around a high percentage of activities of short duration and a very low proportion of activities of more than an hour in length. On a more general level, all participated in telephone conversations, scheduled and unscheduled meetings, and tours; a11. processed mail. There are, however, differences between study participants. This section will be devoted to a discussion of four factors that appeared to have some connection to workday differences--job functions, time of year when observed, personal style/philosophy of subject, and physical facilities. For each of the four factors, study data illustrative of workday differences will be presented and analyzed.

\section{Job Functions}

Mintzberg (1973) asserted, "Considerable evidence has been found to indicate that the particular function that is supervised accounts in large part for the variations in managers' work" (p. 114). The results of this study seem to substantiate such a view. For three of the observed vice-principals, student discipline is a major function. The job assignments of the two other assistant principals differ from this group and from each other. One is responsible for curriculum development and supervision of instruction; the other, for a wide variety of administraive duties, including neither discipline nor curriculum/instruction: special education, safety, and plant maintenance, to name a few. 
The curriculum and instruction assistant principal is in many ways unique. Assistant Principal \#4 had the fewest number of both activities (range: 164-368) and verbal activities (range: 131-338) and saw the fewest people in a week (range: 530-1438). That administrator devoted the most time (range: $2 \mathrm{hr} .45 \mathrm{~min} .-7 \mathrm{hr} .12 \mathrm{~min}$. ) and the highest proportion of worktime (range: $7 \%-26 \%$ ) to desk work. Assistant Principal \#4 spent the highest percentage of time (range: 12\%-35\%) in scheduled meetings but participated in the smallest number of unscheduled meetings (range: 53-158). In addition, that assistant principal was involved in the smallest proportions of both contacts and contact time with clients, the most with subordinates. While for the remainder of the sample, from 20 percent to 34 percent of contacts and from 18 percent to 29 percent of verbal time were with students and their parents or guardians, for Assistant Principal \#4 those percentages were only nine and 17 percent, respectively. On the other hand, 67 percent of Assistant Principal \#4's contacts and 44 percent of verbal contact time were with subordinates, though for other sample members, the ranges were 37-54 percent of contacts and 29-38 percent of contact time. All of these variations could be seen as proceeding from this assistant principal's major functions. The curricular and instructional tasks require scheduled observations, preand post-observation conferences with teachers, and writing sessions to review notes and prepare evaluation reports--all leading to a workday of fewer and longer planned activities, more desk work, and an emphasis on interactions with adults in the building. Differences in written communications are possibly as closely related to job function. The assistant principal for curriculum/instruction far exceeded the rest of 
the sample members in output of reports (eight percent versus zero percent for remainder of the sample) and acknowledgments to verbal contacts (19 percent versus a range of 0-2 percent for other assistant principals). Both these acknowledgments and formal reports result from the teacher observation and evaluation tasks. The former communication is employed to provide the teacher with immediate feedback; the latter is the formal, legal evaluation document nomally written at a later date.

Beyond the obvious fact that that assistant principals with disciplinary duties were the only assistant principals spending verbal contact time for the purposes of student discipline and/or counseling, other similarities to one another, and differences from the other two viceprincipals, are evident. The three disciplinary assistants participated in both the highest numbers of total activities $(368,272$, and 259 as opposed to 217 and 164) and the most unscheduled meetings (158, 109, and 99, compared to 10 and 53). Variations from the other assistant principals are also found in the mail categories. Whereas discipline assistant principals sent out approximately half $(46 \%-58 \%)$ the number of pieces of mail that they received, for the other two the percentages are closer to one-third (35\% and $33 \%)$. In addition, the discipline assistants, as a group, far exceed their counterparts in the proportion of forms used for mail output ( $78 \%, 66 \%$ and $48 \%$, as compared to $24 \%$ and $32 \%$ ). Again, these variations could be reasonably viewed as resulting from differing job functions. A typical scenario for the discipline administrator was: a teacher sends in a referral form, recounting a student's misbehavior; the vice-principal calls the student out of class; they confer; and the assistant principal replies to the teacher's referral, summarizing the 
conference and the action taken. Many of these cycles often occurred in a single day; therefore, the assistant principal conducted numerous hastily-arranged, short meetings and responded in writing to form after form.

Personal Style and Philosophy

A second factor that may wel1 contribute to differences in assistant principal workdays is the personal style and philosophy of individual assistant principals. Mintzberg (1973), in fact, has said, "The evidence shows that the incumbent's values, personality, and style, all contribute to the determination of the work he does" (p. 118). The following represents two illustrations of how unique personal attitudes to the workday may result in actual differences between assistant principals' workdays:

- While on a tour, Assistant Principal \#1 remarked that the day could be spent sending out memos, but, "I'm not that kind of person." This attitude could be a reason for the minimal attention given to written correspondence, the high involvement in the more active tours, and the large numbers of people involved in verbal contacts. This assistant principal spent the highest proportion of time in tours (range: $17 \%-47 \%$ ) but the smallest proportion of time on desk work (range: $7 \%-25 \%$ ). Further, when processing written correspondence, Assistant Principal $\frac{\| 1}{\pi}$ skimmed 41 percent of the incoming mail (compared to a range of 2-12 percent for the rest of the sample) and read only 20 percent while the remaining assistant principals read from 43-53 percent of their incoming correspondence. Perhaps as a result of the concentration on touring 
rather than desk-bound work, this administrator also interacted with a great number of people (1373) in a week.

- Assistant Principal \#2 stated, "I don't like last minute things." The data regarding the meetings in which this administrator engaged appear consistent with such an orientation. The range of scheduled meetings occuring in five days for the combined sample was 7-18; the range of time spent in unscheduled meetings, from 10 percent to 34 percent. The results for Assistant Principal \#2 fall at the upper limit for number of scheduled meetings and the lower limit for time in unscheduled meetings. It may be that this assistant principal's preference for planned events had led to the comparatively large number of scheduled meetings and small proportion of times in unplanned conferences.

\section{Time of Year}

The third potential basis for difference in workdays--time of the year--is striking when the desk sessions and mail of Assistant Principal \#3 are analyzed. The range of number of desk sessions for the sample was 30-46; for total pieces of mail processed, 66-153. In both cases, this assistant principal exceeded all colleagues. Also, Assistant Principal \#3 had the highest proportion of input of carbon copies (44 percent compared to the composite sample's 14 percent), of input from building subordinates (91 percent, with the composite sample at 64 percent), of output in the form of letters (24 percent opposed to a composite 11 percent), of outgoing correspondence to clients (24 percent; the combined sample, 10 percent). The reason for all of these discrepancies seemed clear: this subject was observed during the time in the semester that enough absences could have accrued for students to be officially with- 
drawn from class at teacher request, as well as the time when student progress reports were to be sent home by teachers. Thus, many pieces of mail from teachers, both copies and originals, crossed this assistant principal's desk. These required a good deal of paper work, including replies to subordinates and formal letters of class withdrawal to students' families.

\section{Physical Facilities}

Physical facilities may also contribute to workday differences. Two indications of this possibility were found in this study: one relative to the school grounds; another, to the office spaces of assistant principals. As previously explained, Assistant Principal \#1 devoted the highest percentage of time to tours $(47 \%)$ and the lowest percentage to desk sessions (7\%) and, perhaps as a result, communicated with numerous people in a week (1373). This individual's campus is bordered by a large city park. Because boundaries between city and school property are so nebulous and certainly not observed by large groups of students, the area Assistant Principal \#1 must patrol is very extensive. Since this area was frequented by students skipping classes and reportediy exchanging drugs, there were clear reasons for the administration to supervise this area. It may be that size of grounds and park alone necessitated this assistant principal's heavy commitment to touring.

McCaskey (1979), alluding to the importance of office design, stated, "The first thing to understand about place is that it represents territory" (p. 138). He elaborated further, saying, "Boundaries give security and privacy, protecting one from unwanted encroachments by others (at least boundaries make the statement that they are unwanted)" 
(p. 138). Typically, sampled assistant principals offices were in an office complex--the counseling center or the main office--with their secretaries some distance away. Only Assistant Principal \#2 had a rather removed office, with the secretary seated directly in front of the door. This assistant principal also was found to have had the highest number of scheduled meetings in five days (18) and the lowest proportion of time in unscheduled meetings (10\%). Perhaps these figures could be attributed to the somewhat less accessible office and the positioning of the secretary who can receive unexpected visitors. The two factors together may a 1 low Assistant Principal \#2 to exert more control over the pace of the workday.

None of the elements considered--job function, time of year, personal style/philosophy, nor physical space--can, as a result of this study, be determined to be causative and leading directly to manager workday differences. The foregoing remains necessarily speculative. Additionally, an interaction of factors could be operating--for example, personal philosophy and office configuration. The data do, however, point to some rather intriguing topics for quite focused future research projects.

$\frac{\text { Workday Parallels of Superintendents, }}{\text { Principals, and Assistant Principals }}$

The recent application of structured-observation methods to the study of principals (Crowson \& Porter-Gehrie, 1980; Peterson, 1978) and superintendents (Pitner, 1978) allows the investigator the opportunity of creating a tentative synthesis workday description of three line administrators. The section that follows relates the parallel findings regarding the workday dimensions explored in this study: activities, 
pace, duration of workday, contacts, degree of work initiation/reaction, and workday differences. For the most part, Tables IV, VI, IX, X, and XII provide the references to this study.

\section{Activities}

For superintedents and principals, work was verbal in nature. Superintendents spent an average of 31 of the week's hours in verbal contact (Pitner, 1978, p. 111); assistant principals, 29 hours. However, the dispersion of worktime among activities differed for the two administrators. In particular, superintendents devoted a higher percentage of time to scheduled meetings (51 percent versus 24 percent) while assistant principals spent a greater proportion of their time in unscheduled meetings (24 percent compared to 10 percent) and tours (34 percent as opposed to 2 percent) (Pitner, 1978, Table 10, p. 92) Principals also were observed to employ the tour as a "coping mechanism" (Crowson \& Porter-Gehrie, 1980).

Duration of Workday

Both superintendents and assistant principals worked, on the average, essentially the same number of hours per week and per day: superintendents, 43 hours a week (or a workday of 8 hours and 36 minutes) (Pitner, 1978, p. 111); assistant principals, 42 hours and 33 minutes (equalling 8 hours and 31 minutes per day).

Pace

The pace of daily work of these three school administrators was uniformly rather hectic, with brevity and fragmentation as hallmarks of this pace. For superintendents, 60 percent of work activities lasted 
less than 9 minutes; only six percent exceeded an hour (Pitner, 1978, p. 166). For the assistant principal, those percentages were: 75 percent of activities lasting less than nine minutes; one percent of more than an hour in duration. Peterson (1978) also found principal's activities were short and varied: 35 percent of principals' tasks lasted under nine minutes, and an average of 13 tasks were undertaken per hour. Crowson and Porter-Gehrie (1980) found that brevity and fragmentation mark the principal's day also: one-fifth of the principals' activities were less than a minute in length; 48 percent, less than four minutes. Though superintendents and assistant principals were quite busy, the activity pace does diminish occasionally. For example, the assistant principal's Tunches and after-school hours were nomally periods of diminished activity.

\section{Interactions}

The majority of the verbal contacts of superintendents and assistant principals were dyadic in nature. Seventy percent of the superintendents' verbal contacts were with one other person (Pitner, 1978, p. 112). The assistant principals' meetings and tours were with a second party in 58 percent of all cases. In addition, superintendents and assistant principals had similar divisions of verbal contact time with persons internal and external to their districts. Superintendents spent 73 percent of their time in verbal contact with people within the organization; 27 percent, with outsiders ( $p .110)$. For assistant principals, those figures are 64 and 36 percent, respectively. Finally, the highest proportions, for both superintendents' and assistant principals' contacts and contact time, were in the total informational category. Forty-eight 
percent of the superintendents' contacts and 40 percent of the assistant principals' contacts were within this category, as were 42 percent of the superintendents' contact time (Pitner, 1978, Table 11, pp. 95-96) and 79 percent of the assistant principals' verbal time.

Initiation/Reaction in the Workday

Superintendents initiated most (56\%) of their contacts (Pitner, 1978, p. 166), as did assistant principals (54\%). Principals also were the initiators of the majority of their activities; in excess of 60 percent were self-initiated (Peterson, 1978). However, both assistant principals and superintendents initiated less mail than they received. The percentages for output mail as proportion of input were 40 percent for superintendents (Pitner, p. 105) and 46 percent for assistant principals. 


\section{CHAPTER $V$}

\section{SUMMARY AND CONCLUSIONS}

\section{Introduction}

Five urban high school assistant principals on the west coast were observed throughout twenty-five days and evenings of school-related work. Subject assistant principals had completed at least two years of experience in the position and at the observation site. Together, they were responsible for a variety of tasks, such as attendance and discipline, activities and athletics, and curriculum and instruction. Mintzberg's work on chief executives (1973) and Pitner's research on suburban school superintendents (1978) provided the basic models for this study's data collection, coding, and analysis. Using the nonparticipant observer role, structured interviews, and the Mintzberg (1973) framework for the recording of information related to the sequence and duration of activities, incoming and outgoing mail, and verbal contacts, six research subproblems were addressed. The tables of data used to formulate responses to each of the six study questions resulted from calculation of frequency counts and percentages for the three observation records' categories. The research questions were:

1. What are the workday activities of an assistant principal?

2. How long is this day?

3. How might the pace of the workday be described?

4. With whom does an assistant principal interact? How? Why? 
5. To what extent is daily work proactive? Reactive?

6. Do the workday of various urban high school assistant principals differ in terms of content, duration, pace, contacts, or degree of work initiation?

The major limitation of this study is the typical 1imitation of many field studies: a restricted sample precludes generalization of study results and conclusions to the entire population. In-depth observation hopefully compensates for this, however, by providing the descriptive detail from which later hypotheses can be developed and tested in more controlled quantitative studies.

In this chapter, the results of the investigation of these six questions will be summarized. In addition, recommendations for researchers and school administrators will be presented.

\section{Summary}

\section{The Activities of an Assistant Principal's Workday}

The assistant principals all processed incoming and outgoing mail at their desks and by the staff mailboxes, received and initiated telephone calls, participated in both formally scheduled and quickly arranged meetings, and made tours to deliver and to gather information. However, the amount of work time alloted to each of these activities was by no means uniform. Telephone calls accounted for only six percent of their time; desk sessions, 17 percent. In combination, scheduled and unscheduled meetings consumed nearly half of worktime, with 24 percent of workdays devoted to each medium. The most unique aspect of the assistant 
principal's school days was found to be the heavy emphasis on observational or informational tours. Assistant principals spent one-third (34\%) of their time on this single activity. The fact that the majority (58\%) of worktime is in unscheduled meetings and tours is significant, as an assistant principal, thus, spends the majority of the workday in what Mintzberg (1973) termed a "stimulus-response environment" (p. 52).

\section{Length of the Assistant Principal's Workday}

Subject assistant principals worked, on the average, somewhat more than a forty-hour week. They averaged a work week of 42 hours and 33 minutes, or a workday of 8 hours and 31 minutes. The amount of time worked daily varied in particular by the presence or absence of extra calendar events, such as games, breakfast meetings, or district meetings. Most of the workday time was, of course, devoted to managerial work-specific examples being phone calls to patrons, counseling or discipline sessions with students, and tours to supervise the cafeteria. However, some of this time was necessarily personal in nature. Assistant principals took coffee breaks and short lunch hours, prepared bank deposits on payday, and called home. As the work week is only slightly more than the traditional 40 hours, the tensions and dissatisfactions sometimes attributed to the assistant principals probably result from work content rather than from work hours.

Pace of the Workday

Though the assistant principals' work pace often slowed down a great deal at lunch time or after the closing bel1, their days normally 
ranged from frenetic to merely busy. The composite sample undertook more than 1,000 (1280) activities during the observed twenty-five days. Activities were sometimes conducted simultaneously. For example, an assistant principal could be in a meeting when the telphone rang and a teacher wishing to share a problem entered the office. All activities were relatively short in duration. Telephone calls averaged two minutes; unscheduled meetings, five minutes; and desk sessions, nine. Tours lasted an average of 12 minutes. Even the scheduled meeting was only 36 minutes, on the average. Perhaps the most striking features of the daily pace are conveyed in the following figures: 75 percent of all activities lasted less than nine minutes; only one percent exceeded an hour. Given this pace, completing tasks requiring a good deal of time and reflection was quite difficult. For example, one assistant principal was required to write a summary of normal discipline procedures--for conferences, suspensions; fights, obscenity, drug possession and use. He sat down to work on this project over and over, often accomplishing little before the next problem was presented to him.

\section{The Assistant Principal's Interactions}

The assistant principal communicated with very large numbers of people--including members of external boards; district support personnel, such as school district police and curriculum specialists; their principals and other superiors in the urban district hierarchy; other assistant principals; colleagues in professional organizations; university personne1; social workers. By far their greatest nuriber of interactions were with building subordinates, however; 64 percent of their input mail 
came from subordinates and 79 percent of output mail went to them. Of a11 verbal contacts, 49 percent were with secretaries, clerks, teachers, aides, and custodians. The second highest proportion of contacts (26\%) was with clients, students and patrons. In addition, external contacts accounted for 36 percent of the total contact time of assistant principals; but internal communications, the majority (64\%) of verbal contact time. Concisely stated, assistant principals devoted their time and energy to those people most deserving of it: the students and parents who are the system's clients; and the professional and non-certificated staff who serve those clients.

The assistant principals, as revealed by the division of worktime among activities, spent much more time in the verbal and observational/ verbal media than with the written word. A high proportion of mail (34\%, input; $53 \%$, output) was by the bureaucracy's forms. When involved in verbal activities--meetings and tours, in particular--assistant principals were often dealing with multiple individuals and participant groups, though the majority of verbal contacts were with only one other person. The major purpose for interactions was informational--to observe, give, receive, review or mutually exchange information. Specifically, 66 percent of mail received, 74 percent of all contacts, and 79 percent of contact time were for this general purpose. The subjects of the assistant principal's contacts are often depressing ones--for example, unhappiness stemming from student problems with teachers, peers, or family. However, the core of the assistant principal's contacts are, like those of managers in other organizations, to process information. 
Initiation and Reaction In the Assistant Principal's Daily Work

An examination of the mail and of the verbal contacts of assistant principals provides somewhat differing answers to this research question. Verbal contacts were more often than not (54\%) initiated by the assistant principal. He or she frequently chose to tour at a given time or voluntarily set up a meeting or initiated a phone call. With the mail, only a slightly different picture emerged. Perhaps the best indicator of reaction/initiation of written communications is that the assistant principal's output is 46 percent of input mail volume. In short, the assistant principal both initiates and responds, with initiation of verbal contacts occuring in slightly higher proportions than initiation of written communications. Learning more about the nature of reaction/ initiation in daily work is probably one of the most pressing needs for future management research. Given the problems besetting large American organizations, it is not very instructive if researchers can only continue to state that managers both react and initiate.

Workday Differences of Assistant Principals

There appears to be some connection between the workday variations of assistant principals and such factors as job function, time of school year, personal style/philosophy of the incumbent, and physical facilities. These connections remain, from this investigation, somewhat tenuous but thought-provoking. Can a calmer, more controlled day result simply from the office arrangement? Do certain times of the academic year lead to clear emphasis on particular activities? Can personal 
beliefs about the nature of one's work, in fact, markedly affect the workday? Do differing job descriptions have a direct link to workday differences?

Assistant principals, when asked to describe their workdays, used many adjectives: tiring, frustrating, busy, hectic, unrewarding, diverse, long, euphoric, depressing, interesting, challenging, fatiguing, exhausting, pleasant. The foregoing summary provides data suggesting that each of these words could, at various times, appropriately describe the urban high school assistant principal's school day.

Workday Parallels of Superintendents, Principals, and Assistant Principals

Since three previous educational administration studies (Crowson \& Porter-Gehrie, 1980; Peterson, 1978; Pitner, 1978) also employed structured-observation methodology, the investigator was able to tentatively join the workday description of assistant principals with those of superintendents and principals. Parallel data were not always available for all three positions, but work characteristics similar to at least two of the positions were:

- An emphsis on verbal activities

- A work week slightly exceeding 40 hours

- Brevity and fragmentation of activities

- Dyadic interactions

- A majority of verbal contact time spent with persons within the district

- A high proportion of contacts and contact time devoted to information processing

- Almost equal proportions of reactive and proactive behaviors 


\section{Recommendations for Researchers}

and School Administrators

Since the literature on the assistant principalship is not extensive and on many topics raises more questions than are answered, there are numerous promising directions for future study consideration by researchers and by prospective and incumbent practitioners of school administration. The investigator, however, chose to specify two recommendations that together could address several of the issues most closely related to this specific study.

\section{Observational Studies of School Administrators}

The observational studies of the last decade on assistant principals (Austin \& Brown, 1970), principals (Crowson \& Porter-Gehrie, 1980; Peterson, 1973; Wolcott, 1973) and superintendents (Pitner, 1978) have all provided provocative information regarding the true nature of managerial work in school systems. In many respects the results challenge traditional theory about management days, giving rise to concerns about the appropriateness of university and district training for school administrators, as well as the hiring of them. These studies are, however, simply beginnings, as samples were small and observations were place-bound. Replication is necessary. A series of observational studies is needed in rural, urban, and suburban locations and with numerous other administrators--if field study results are to be synthesized and generalized and needed hypotheses regarding managerial workdays are to be developed. 
Though replication is certainty necessary, the field of management research would be well served if each replication refined the previous research questions and expanded the methodological approaches. For example, future study of the assistant principal's workday might employ the Mintzberg framework (1973) so that study results can be compared and contrasted to the results of this study. In addition, however, the researcher might revise the means for classifying contact reaction/ initiation, as only nebulous conclusions could be reached regarding this work aspect based on either this study or Austin and Brown's (1970). Also, since at least one observational study has been conducted on the school administration positions of superintendent, principal, and assistant principal, at least propositions, if not hypotheses, regarding school management should be developed from future studies.

Finally, it could be quite productive to employ more ethnographic approaches to the study of managerial workdays in school districts. For example, more extended observations--over longer periods of time and including study of personal life--are needed if several intriguing but tentative notions are to be examined. These notions include the possible social and psychological implications of management pace (Carlson, 1951, p. 75) and the potential cause-effect relationships of personal values, philosophy and style, and time of year to workday differences.

It is also conceivable that informal shadowing of colleagues by prospective and practicing administrators could lead to increasingly appropriate career decisions, local hiring criteria, and inservice 
training programs. It is difficult to determine how to approach any of these personnel elements with only vague conceptions of the real nature of the school administrator's workday.

Exploration of the Proactive and Reactive Work in Formal Organizations

Two of the major focuses of recent observational studies have been reaction versus initiation in the manager's workday and the pace of that day. Additionally, organizational theorists have pointed to the more a11-encompassing concept of uncertainty in modern formal organizations. Today's urban school system in many ways exempiifies organizational uncertainty. Conflicting interest groups and public demands, court decisions, fiscal constraints, and changing federal administrations, all contribute to a rather profound degree of uncertainty. In fact, uncertainty may not be only a haunting concern for upper levels of administration. For assistant principals unceritainty may be a daily, even hourly, condition, as the events that lead to and derive from the frequent unscheduled meetings and routine tours are so unpredictable. The extent to which organizational uncertainty, reactive behaviors, and daily pace are linked is not known. Both administrators and those who conduct research regarding them could enhance the potential of modern organizations if they were more knowledgable regarding workday dimensions, such as reaction/ initiation and pace of day, and the formal organization. When focusing specifically on the concepts of initiation and reaction, both the researcher and the sample members were somewhat troubled by even the terminology of reactive and proactive work activities. Davis and Luthans (1980) recently attempted to define the terms proactive, reactive, and adaptive. Continuing attempts to define these terms, to 
measure the behaviors they describe, and to develop propositions on modification of these behaviors would be valuable if, as both Davis and Luthans (1980) and Stewart (1979) asserted, the ultimate effectiveness of administrators and the organizations they serve can be improved by proper attention to these concepts. Davis and Luthans (1980) maintained that development of social learning theory can serve as a framework to analyze and improve the effectiveness of managerial behaviors: proactive, reactive, and adaptive. Stewart's (1979) recent work is built around three questions: "Do some, or many, managers have explicit agendas, that is, personal plans for what they are trying to achieve? If so, what kinds of explicit agendas can be distinguished? How do agendas of managers in similar jobs differ?" (p. 34) Her speculation that proactive managers with explicit agendas may be more effective, in combination with Davis and Luthans (1980) contention that all three types of management behaviors can be positively modified, offer challenging areas of study for educational researchers and for the administrators attempting to cope with their uncertain environments and their busy workdays, particularly if even a small portion of Stanek's (1980) observations is accurate:

Bureaucratic managers, trained to deal with certainty, find ways to cope with the uncertainty that is costly to the organization. They polarize problems into black or white, shorten time horizons (for example, put off the five-year plan), search for routines, delight in trivia, react rather than proact, flare up, withdraw, work harder and longer, write more reports, hold more meetings, make more visits, escape into excessive behavior or the use of drugs or drink, and eventually break down. (p. 46) 


\section{Reference Notes}

1. My1nechuk, Larry. Personal Communication, March 19, 1980.

2. Wolcott, Harry F. Mirrors, models and monitors: Educator adaptions of the ethnographic innovation (2nd draft, Geo. Spindler [Ed.J). Book in prepartion, March 1979.

3. Wol cott, Harry. Personal communication, May 27, 1980. 


\section{Bibliography}

The assistant principal: A collection of ERIC document resumes. Eugene, OR: University of Oregon, 1973. (ERIC Document Reproduction Service No. ED 073 563)

Austin, David B. The assistant principal--What does he do? Theory into Practice, February 1979, 11(1), 68-72.

Austin, David B., \& Brown, Harry L., Jr. Report of the assistant principalship. volume 3: The study of the secondary school principalship. Washington, D.C.: National Association of Secondary School Principals, 1970. (ERIC Document Reproduction Service No. ED 053 499)

Barratt, Thomas K. Assistant principals. School Board Journal, 1955, 130,56 .

Becker, Howard S., Geer, Blanche, Hughes, Everett C., \& Strauss, Anselm L. Boys in white: Student culture in medical school. Chicago: University of Chicago Press, 1967.

Bevan, John K., Bugher, William D., Mazzei, Renato, Moore, Barry, \& Nichols, Ted. What does an assistant principal do? Several tell how they spend a work week. NASSP Bulletin, October 1973, 57, 81-99.

Black, Alice Brenda. Clarifying the role of the assistant principal. NASSP Bulletin, May 1980, 64, 33-39.

Blau, Peter M., \& Scott, Richard W. Formal organizations. San Francisco: Chandler Publishing Company, 1962.

Boettcher, Brian E. Is due process changing the role of the assistant principal? NASSP Bulletin, October 1973, 57, 75-80.

Bordinger, Donald L. Making the assistant principalship a career position. NASSP Bulletin, October 1973, 57, 10-15.

Brown, Glenn J., \& Rentschler, James E. Why don't assistant principals get the principalship? NASSP Bulletin, October 1973, 57, 36-47.

Burgess, Lovola. The new assistant principal--Key person in the principal's team. (Paper presented at the National Association of Secondary School Principals Annual Convention, Anaheim, March 1972). (ERIC Document Reproduction Service No. ED 062 717) 
Burgess, Lovola. Accepting the challenges of career development. NASSP Bulletin, October 1973, 57, 48-52.

Burgess, Lovola. The assistant principalship: Where now? NASSP Builetin, April 1976, 60, 67-81.

Burns, Tom. The directions of activity and communications in a departmental executive group. Human Relations, 1954, ㄱ, 73-97.

Carlson, Sune. Executive behavior: A study of the work load and working methods of managing directors. Stockholm: Strombergs, 1951 .

Childress, Jack. Cited in, assistant principals need role definition, keynoter says. NASSP Newsletter, December 1972, 20(4),

Childress, Jack R. The challenge of the assistant principalship. NASSP Bulletin, October 1973, 57, 1-9.

Clements, J. Enhancing the role of the assistant principal. NASSP Bulletin, May 1980, 64, 14-22.

Cohen, Michael D., \& March, James G. Leadership and ambiguity. New York: McGraw-Hi71, 1974.

Collins, Daniel $J$. The assistant principal as antagonist. NASSP Bulletin, 1976, 60, 65-69.

Croft, John C., \& Morton, John R. The assistant principal: In quandry or comfort? Paper presented at the Annual Meeting of the American Educational Research Association, New York, 1977. (ERIC Document Reproduction Service No. ED 136 392)

Crowson, Robert L., \& Porter-Gehrie, Cynthia. The discretionary behavior of principals in large-city schools. Educational Administration Quarterly, Winter 1980, 10(1), 45-69.

Culver, Ted. The assistant principal: Administrator or policeman? NASSP Bulletin, January 1978, 62, 112-114.

Cusick, Philip A. Inside high school: The student's world. New York: Holt, Rinehart \& Winston, Inc., 1973.

Davis, Tim R. V., \& Luthans, Fred. Managers in action: A new look at their behavior and operating modes. Organizational Dynamics, Summer $1980, \underline{9}(1), 64-80$.

Dohan, Margaret. Principals and vice-principals. bibliographies in education. no. 65. Ottawa: Canadian Teachers' Federation, 1978. (ERIC Document Reproduction Service No. 168 163) 
Dubin, Robert S. Business behavior behaviorally viewed. In George B. Strather (Ed.), Social science approaches to business behavior. Homewood, Illinois: The Dorsey Press, Inc. \& Richard D. Irwin, Inc., 1976.

Dubin, Robert, \& Spray, S. Lee. Executive behavior and interaction. Industrial Relations, 1964, 8, 99-108.

Egan, Peter William. The assistant principalship with emphasis on its relationship to the principalship (Doctoral dissertation, Northwestern University, 1969). (University Microfilm No. 70-44)

Fallon, Bernard V. Advice to the prospective assistant principal. NASSP Bulletin, 1974, 58, 76-80.

Garawski, Robert A. The assistant principal: His job and organizational potency. Clearing House, September 1978, 52(1), 8-10.

Gatti, Richard D., \& Gatti, Daniel J. Encyclopedic dictionary of school Iaw. West Nyack, NY: Parker Publishing Company, Inc., 1975.

Gillespie, T. Marcus. The assistant principal: Status, duties, and responsibilities. National Association of Secondary Schooi Principals, $1961,4 \underline{5,59-68 .}$

Glaser, Barney G., \& Strauss, Anselm L. The discovery of grounded theory: Strategies for qualitative research. Chicago: Aldine Publishing Company, 1967.

Greenham, William $H$. Who is the assistant principal? Explorations into an elusive role. American Secondary Education, September $1972, \underline{2}(4), 27-32$.

Gross, Richard A., Shapiro, Marvin, \& Meehan, John. Principals and assistants: How the management team can succeed. NASSP Bulletin, May 1980, 64, 26-28.

Guest, Robert H. Of time and the foreman. Personnel, 1956, 32, $478-486$.

Hencley, Stephen P. Functional interrelationships within administrative performance systems. In Donald J. Leu \& Herbert D. Rudman (Eds.), Preparation programs for school administrators: Common and specialized learnings. East Lansing, Michigan: Dffice of Research and Publications, College of Education, Michigan State University, 1963.

Hentges, Joseph T. A normative study of the assistant principalship in selected Minnesota secondary schools (Ed. Specialist thesis, Mankato State University, 1976). (ERIC Document Reproduction Serice No. ED 163 148) 
Hurley, Leo. The vice principal. NASSP Bulletin, 1965, 49, 12-14. Hurwitz, Howard L. A day in the life of an administrative assistant. High Points: The Work of the High Schools of New York City, October 1957, 39(7), 23-25.

Jarrett, R. W. The activities of the assistant principal in secondary schools. The Bulletin of the National Association of Secondary School Principals, September 1958, 42, 28-32.

Job description for the assistant principal. NASSP Bulletin, May 1980, $\underline{64}, 51-55$.

Joly, Roxee $W$. A principal looks at the assistant principal. NASSP Bulletin, October 1973, 57, 16-27.

Koerner, Thomas F. After-thoughts: The editor comments. NASSP Bulletin, October 1973, 57, 124-125.

Kriekard, John A., \& Norton, M. Scott. Using the competency approach to the assistant principalship. NASSP Bulletin, May 1980, 64, $1-8$.

Leu, Donald J., \& Rudman, Herbert C. (Eds.) Preparation programs for school administrators: Common and specialized Tearnings. East Lansing, Michigan: Office of Research and Publications, College of Education, Michigan State University, 1963.

Livingston, Sterling. Myth of the well-educated manager. Harvard Business Review, 1971, 49, 79-80.

Lutz, Frank W., \& Iannaccone, Laurence (Eds.). Understanding educational organizations: A field study approach. Columbus, Ohio: Charles E. Merrit1 Publishing Co., 1969.

Long, Charles M. Duties of secondary school vice principals. National Association of Secondary School Principals, February 1957, 4II(226), 26-37.

March, James G. \& Simon, Herbert A. Organizations. New York: Wiley, 1958.

Mazzei, Renato. What is a vice-principal? Clearinghouse, 1976, 49, 319.

McCal1, Morgan W., Jr. Leaders and leadership: Of substance and shadow. In J. R. Hackman, E. E. Lawler III, \& L. W. Porter (Eds.), Perspectives on behavior in organization. New York: McGrawHilT, 1977.

McCaskey, Michael $\mathrm{W}$. The hidden messages managers send. Harvard Business Review, November-December 1979, 56, 135-148. 
Mintzberg, Henry. Structured observation as a method to study managerial work. The Journal of Management Studies, $1970, \underline{I}(1)$, $B-97-B-110$.

Mintzberg, Henry. Managerial work: Analysis from observation. Management Science, October 1971, 18(2), B-97-B-110.

Mintzberg, Henry. The nature of managerial work. New York: Harper \& Row, 1973.

Mintzberg, Henry. The manager's job: Folklore and fact. Harvard Business Review, July-August 1975, 53(4), 49-61.

Mitchell, Mack. As disciplinarians assistant principals can be effective counselors, mediators. NASSP Bulletin, May 1980, 64, 29-32.

Novak, Benjamin J. Examining the role of the vice-principal. American School Board Journal, June 1963, 146(6), 19-20.

Ogilvie, Doug. Leadership and the high school deputy principa?. The Journal of Educational Administration, 1977, 15(1), 92-103.

Peterson, Kent D. The principal's tasks. Administrator's Notebook, $1978,26(8), 1-4$.

Pitner, Nancy Josephine. Descriptive study of the everyday activities of suburban school superintendents: The management of information (Doctoral dissertation, The Ohio State University, 1978). (University Microfilms No. 7908199)

Potter, James M., Jr. Ten suggestions: Enhancing the role of the assistant principal. NASSP Bulletin, May 1980, 64, 9-12.

Principals and vice-principals. Bibliographies in education, No. 51. Ottawa: Canadian Teachers Federation, 1975. (ERIC Document Reproduction Service No. 114995 )

Rankin, Donald L. A unified approach to administration. NASSP Bulletin, October 1973, 57, 70-74.

Rist, Ray C. BTitzkrieg ethnography: On the transformation of a method into a movement. Educational Researcher, 1980, 9 , 8-10.

Salley, Columbus, McPherson, R. Bruce, \& Baehr, Melany E. What principals do: A preliminary occupational analysis. In Donald A. Erickson \& Theodore L. Reller (Eds.), The Principal in Metropolitan Schools. Berkley: McCutchan Publishing Corp., 1979.

Sarason, Seymour B. The culture of the school and the problem of change. Boston: Allyn \& Bacon, Inc., 1971. 
Smerka, Terrence J. A 'modus operandi' for the assistant principal. NÁSSP Bulletin, May 1980, 64, 23-25.

Smith, Louis M., \& Keith, Pat M. Anatomy of an educational innovation: An organizational analysis of an elementary school. New York: John Wiley \& Sons, Inc., 1971.

Spindler, George D. The role of the school administrator. In George D. Spindler (Ed.), Education and culture: Anthropological approaches. New York: Holt, Rinehart and Winston, 1973.

Sprague, Nancy F. Involing the assistant principal on the administrative team. HASSP Bulletin, October 1973, 57, 28-35.

Stanek, Lou Willet. Women in Management: Can it be a renaissance for everybody? Management Review, November 1980, 69(11), 44-43.

Stewart, Rosemary. Managers and their jobs: A study of the similarities and differences in the ways managers spend their time. London: MacMillan, 1967.

Stewart, Rosemary. Managerial agendas--Reactive or proactive? Organizational Dynamics, Autumn 1979, $\underline{8}(2), 34-47$.

Stokes, Russe11, ur. The assistant principal's student activities arena. NASSP Bulletin, October 1973, 57, 63-69.

Thompson, James D. Organizations in action. New York: McGraw-Hill Book Company, 1957.

Turner, Harold E. The VPI as a VIP. NASSP Bulletin, October 1973, 57, 53-62.

Valentine, Jerry. Preparing your assistant for the principalship. NASSP Bulletin, May 1980, 64, 40-43.

Van Eman, Charles R. The functions of the assistant high school principal and other assistant executives. Educational Research Bulletin, 1926, $\underline{5}, 148-150$.

Weick, Karl E. Systematic observational methods. In Gardner Lindzey \& Elliot Aronson (Eds.), The handbook of social psychology (2nd Ed.) (Vol. 2). Men1o Park, CA: Addison-Westey Publishing Company, 1968.

Wells, Philip C., Nelson, Robert H., \& Johnsen, Earl M. The assistant secondary school principal. NASSP Bulletin, 1965, 49, 15-22.

Whistler, Thomas $L$. The "assistant-to" in four administrative settings. Administrative Science Quarterly, 1960, $\underline{5}, 181-216$.

Whyte, William H., Jr. How hard do executives work? Fortune, January 1954, 49, pp. 108-111, 148, 150-152. 
Wolcott, Harry. An ethnographic approach to the study of school administrators. In Albert $H$. Yee (Ed.), Social interaction in educational settings. Englewood Cliffs, $\mathrm{NJ}$ : Prentice-Ha71, Inc., 1971. (a)

Wolcott, Harry. Handle with care: Necessary precautions in the anthropology of schools. In Murray L. Wax, Stanley Diamond, \& Fred 0. Gearing (Eds.), Anthropological perspectives on education. New York: Basic Books, Inc., 1971. (b)

Wolcott, Harry $F$. The man in the principal's office: An ethnography. New York: Holt, Rinehart \& Winston, Inc., 1973.

Wolcott, Harry F. Ethnographic approaches to research in education: A bibliography on method. Eugene, OR: Center for Educational Policy and Management, University of Oregon, 1974. (a)

Wolcott, Harry. The elementary school principal: Notes from a field study. In George Dearborn Spindler (Ed.), Education and cultural process: Toward an anthropology of education. New York: Holt, Rinehart and Winston, Inc., 1974. (b)

Wolcott, Harry. Criteria for an ethnographic approach to research in schools. Human Organization, 1975, 34(2), 111-125.

Wolcott, Harry. Study guide for ethnographic research methods in education. Washington, D.C.: American Educationa? Research Association, nd. 
APPENDIXES 
Appendix A

Structured-Observation Forms 
Chronology Record

Assistant

Principal

Day, Date

\begin{tabular}{ll}
\hline Time & $\begin{array}{l}\text { Medium } \\
\text { UnscheduTed Meeting } \\
\text { Scheduled Meeting } \\
\text { Desk Work }\end{array}$ \\
Shone Ca11
\end{tabular}


Assistant

Written Communication Record

Principal

Day, Date

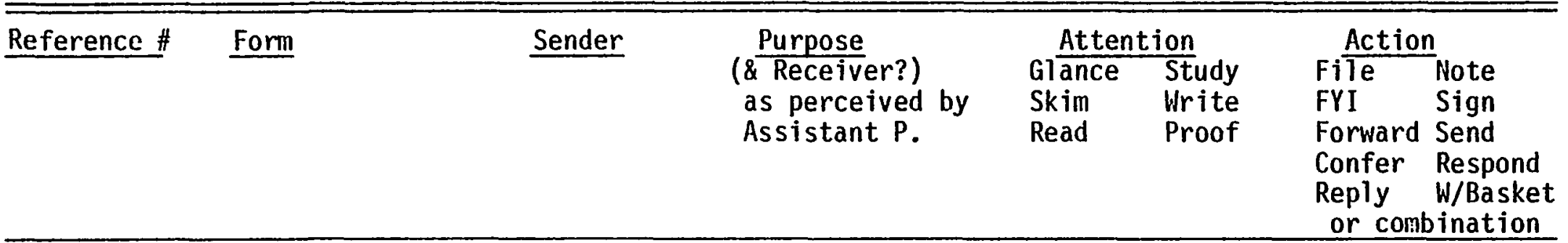


Day, Date

\begin{tabular}{|c|c|c|c|c|c|c|}
\hline Reference & Medium & Purpose & Participant(s) & \# Participants & $\begin{array}{l}\text { Initiation } \\
\text { Self } \\
\text { Contact } \\
\text { Mutual } \\
\text { Clock }\end{array}$ & $\begin{array}{l}\text { Place } \\
\text { 1. Superior's Office } \\
\text { 2. A.P.'s Office } \\
\text { 3. Peer's Office } \\
\text { 4. Subord. 's Office } \\
\text { 5. Hall/Piant/Ground } \\
\text { 6. Conf./Bd. Rm. } \\
\text { 7. Elsewh./Dist. } \\
\text { 8. Community } \\
\text { 9. Away/Org. }\end{array}$ \\
\hline
\end{tabular}


Appendix B

Interview Schedule 


\section{INTERVIEW SCHEDULE}

1. What would you say if you were asked to describe the job of assistant principal to someone totally unfamiliar with the position?

2. What kind of person do you think makes a good assistant principal?

3. Is the assistant principalship what you expected it to be?

4. What are your satisfactions as an assistant principal? How could those satisfactions be increased?

5. What leads to dissatisfaction with your position?

6. To what degree and in what ways does the principal affect the assistant principal's level of job satisfaction?

7. What adjectives would you use to describe your typical workday as an assistant principal?

8. What are the activities of a typical school day as an assistant principal?

9. Could you describe your typical working hours, including evenings and weekends?

10. How might the pace of your workday be described?

11. With whom does an assistant principal interact? How? Why?

12. To what extent do you consider your work as assistant principal proactive? Reactive?

13. Do you think your workday is similar to/different from the workdays of other urban high school assistant principals?

14. What was I not able to observe about your workdays in the five days I was here?

15. What are you future career plans?

16. Do you think experiences as an assistant principal provide adequate and appropriate preparation for a principalship? 
Appendix $C$

Chronology Records 
CHRONOLOGY RECORD

ASSISTANT PRINCIPAL $\$$

\begin{tabular}{|c|c|c|c|c|c|c|}
\hline Ca tecory & Day 1 & Dav? & Day 3 & Day 4 & Dav 5 & Totai \\
\hline Total hours worked & $447 \mathrm{~min}$ & $452 \min$ & 437 min & 435 min & $464 \min$ & $\begin{array}{l}37 \mathrm{hr} \\
15 \mathrm{~min}\end{array}$ \\
\hline $\begin{array}{l}\text { Hours in evening events } \\
\text { (included) }\end{array}$ & $42 \min$ & $90 \mathrm{~min}$ & $0 \min$ & 0 min & 0 min & $\begin{array}{rl}2 & \mathrm{hr} \\
12 \mathrm{~min}\end{array}$ \\
\hline $\begin{array}{l}\text { Hours in travel to outside events } \\
\text { (not included) } \\
\text { Total number of activities } \\
\text { Total amount of mail } \\
\text { Average amount of mail processed per day }\end{array}$ & $\begin{array}{l}10 \text { min } \\
58 \\
21 \\
-\end{array}$ & $\begin{array}{l}40 \text { min } \\
58 \\
20 \\
-\end{array}$ & $\begin{array}{l}0 \text { min } \\
77 \\
41 \\
-\end{array}$ & $\begin{array}{l}0 \text { min } \\
93 \\
28 \\
-\end{array}$ & $\begin{array}{l}0 \text { min } \\
82 \\
16 \\
\end{array}$ & $\begin{array}{l}50 \mathrm{~min} \\
368 \\
126 \\
25\end{array}$ \\
\hline \multicolumn{7}{|c|}{ Desk Work } \\
\hline $\begin{array}{l}\text { Number of sessions } \\
\text { Time on desk work }\end{array}$ & 25 min & $\begin{array}{l}5 \\
46 \text { min }\end{array}$ & $\begin{array}{r}5 \\
39 \\
\text { min }\end{array}$ & 21 min & $\begin{array}{l}8 \\
33 \text { min }\end{array}$ & \multirow{2}{*}{$\begin{array}{l}30 \\
2 \mathrm{hr} \\
45 \mathrm{~min} \\
6 \mathrm{~min} \\
7 \%\end{array}$} \\
\hline $\begin{array}{l}\text { Avarage duration } \\
\text { Proportion of time }\end{array}$ & $\begin{array}{l}5 \mathrm{~min} \\
6 *\end{array}$ & ${ }_{10 \%}^{9}$ min & $\begin{array}{l}3 \min \\
9 \%\end{array}$ & $\begin{array}{l}3 \min \\
5 \%\end{array}$ & $\begin{array}{l}4 \text { min } \\
7.0\end{array}$ & \\
\hline \multicolumn{7}{|c|}{ Telephone Calls } \\
\hline $\begin{array}{l}\text { Number of calls } \\
\text { Time on telephone }\end{array}$ & $\begin{array}{l}12 \\
35 \text { min }\end{array}$ & $\begin{array}{l}13 \\
21 \mathrm{~min}\end{array}$ & $\begin{array}{l}26 \\
58 \text { min }\end{array}$ & $\begin{array}{l}25 \\
55 \mathrm{~min}\end{array}$ & 25 min & \multirow{2}{*}{$\begin{array}{l}101 \\
4 \text { hr } \\
1 \text { min } \\
2 \min \\
11 \%\end{array}$} \\
\hline $\begin{array}{l}\text { Average duration } \\
\text { Proportion of time }\end{array}$ & $\begin{array}{l}3 \text { min } \\
8 \%\end{array}$ & $\sum_{5 \%}^{2} \min$ & $\frac{2}{13 \%} \min$ & $2 \mathrm{~min}$ & $\frac{3 \text { min }}{16 \%}$ & \\
\hline \multicolumn{7}{|c|}{ Scheduled Meetings } \\
\hline $\begin{array}{l}\text { Number of meetings } \\
\text { Time in meetings }\end{array}$ & $3 \frac{1}{m i n}$ & $89 \min$ & 93 min & $42 \min$ & $26 \min$ & \multirow{2}{*}{$\begin{array}{l}9 \\
4 \mathrm{hr} \\
46 \mathrm{~min} \\
32 \min \\
13 \%\end{array}$} \\
\hline $\begin{array}{l}\text { Average duration } \\
\text { Proportion of time }\end{array}$ & $\begin{array}{l}36 \text { min } \\
8 \%\end{array}$ & $\begin{array}{l}30 \text { min } \\
20.5\end{array}$ & $\begin{array}{l}46 \min \\
27 \%\end{array}$ & $\begin{array}{l}21 \text { min } \\
10 \%\end{array}$ & $\begin{array}{l}26 \min \\
6 \%\end{array}$ & \\
\hline \multicolumn{7}{|c|}{ Unscheduled Meetings } \\
\hline $\begin{array}{l}\text { Number of meetings } \\
\text { Time in meetings }\end{array}$ & $\begin{array}{r}24 \\
129 \min \end{array}$ & $112 \mathrm{~min}$ & 127 min & 207 min & 180 min & \multirow{2}{*}{$\begin{array}{l}153 \\
12 \mathrm{rr} \\
36 \mathrm{~min} \\
5 \mathrm{~min} \\
34 \%\end{array}$} \\
\hline $\begin{array}{l}\text { Average duration } \\
\text { Proportion of time }\end{array}$ & $\begin{array}{l}5 \text { min } \\
29 \%\end{array}$ & $\begin{array}{l}45 \% \\
25 i n\end{array}$ & ${ }_{20 \%}^{5} \min$ & $\begin{array}{l}4 \text { min } \\
42 \%\end{array}$ & $5 \mathrm{~min}$ & \\
\hline \multicolumn{7}{|c|}{ Tours } \\
\hline $\begin{array}{l}\text { Number of tours } \\
\text { Time on tours }\end{array}$ & $\begin{array}{l}16 \\
248 \mathrm{~min}\end{array}$ & $211^{9} \min$ & $\begin{array}{r}17 \\
189 \mathrm{~min}\end{array}$ & $\begin{array}{l}10 \\
182 \text { min }\end{array}$ & 221 min & \multirow{2}{*}{$\begin{array}{l}70 \\
17 \mathrm{hr} \\
31 \mathrm{~min} \\
15 \min \\
47 \%\end{array}$} \\
\hline $\begin{array}{l}\text { Average duration } \\
\text { Proportion of time }\end{array}$ & $\begin{array}{l}15 \min \\
55 \%\end{array}$ & $\begin{array}{l}23 \min \\
47 \%\end{array}$ & $\begin{array}{l}11 \text { min } \\
43 \%\end{array}$ & $\begin{array}{l}18 \mathrm{~min} \\
42 \%\end{array}$ & $\begin{array}{l}12 \min \\
48 \%\end{array}$ & \\
\hline \multicolumn{7}{|c|}{ Length of Activities } \\
\hline $\begin{array}{l}\text { Proportion of activities lasting less } \\
\text { than } 9 \text { minutes } \\
\text { Proportion lasting longer than } 60 \text { minutes }\end{array}$ & $\begin{array}{r}79 \% \\
2 \%\end{array}$ & $\begin{aligned} 74 \stackrel{y}{m} \\
2 \stackrel{\%}{\%}\end{aligned}$ & $\begin{array}{r}81 \% \\
0 \%\end{array}$ & $\begin{array}{r}78 \% \\
0 \%\end{array}$ & $\begin{array}{r}77 \% \\
0 \%\end{array}$ & $\begin{array}{l}78 \% \\
1 \%\end{array}$ \\
\hline
\end{tabular}


CHRONOLOGY RECORO

AJSISTANT PRINCIPAL $\% 2$

\begin{tabular}{|c|c|c|c|c|c|c|}
\hline Category & Day 1 & Day 2 & Day 3 & Day 4 & Day 5 & Total \\
\hline Total hours worked & 516 min & $426 \min$ & 429 min & 376 min & 575 min & $38 \mathrm{hr}$ \\
\hline Hours in evening events (inciuded) & 145 min & 0 min & $50 \min$ & $64 \mathrm{~min}$ & $185 \min$ & $\begin{array}{rl}7 & \mathrm{hr} \\
24 & \min \end{array}$ \\
\hline $\begin{array}{l}\text { Hours in travel to outside events } \\
\text { (not included) }\end{array}$ & 30 min & 0 min & 30 min & $30 \min$ & $15 \min$ & $\begin{array}{l}1 \mathrm{hr} \\
45 \mathrm{~min}\end{array}$ \\
\hline Total number of activities & $\begin{array}{l}31 \\
18\end{array}$ & 51 & 58 & $\begin{array}{l}43 \\
10\end{array}$ & $\begin{array}{l}34 \\
10\end{array}$ & $\begin{array}{r}217 \\
66\end{array}$ \\
\hline Average amount of mail processed per day & - & - & - & - & - & 13 \\
\hline \multicolumn{7}{|c|}{ Desk Hork } \\
\hline $\begin{array}{l}\text { Number of sessions } \\
\text { Time on desk work }\end{array}$ & $90 \mathrm{~min}$ & 60 min & 171 min & 59 min & $4 \frac{3}{\min }$ & \multirow{2}{*}{$\begin{array}{l}32 \\
5 \mathrm{hr} \\
56 \mathrm{mir} \\
11 \mathrm{mir} \\
15 \%\end{array}$} \\
\hline $\begin{array}{l}\text { Average duration } \\
\text { Preportion of time }\end{array}$ & 11 min & $\begin{array}{l}10 \mathrm{~min} \\
14 \%\end{array}$ & $24 \%^{3}$ min & $\begin{array}{l}15 \text { min } \\
16_{N}^{*}\end{array}$ & ${ }_{8 \%}^{15} \min$ & \\
\hline \multicolumn{7}{|c|}{ Telephone Calls } \\
\hline $\begin{array}{l}\text { Number of calls } \\
\text { Time on talephone }\end{array}$ & $\begin{array}{l}5 \\
5 \text { min }\end{array}$ & $\begin{array}{l}16 \\
29 \min \end{array}$ & 11 min & $\begin{array}{l}11 \\
26 \\
\text { min }\end{array}$ & $\stackrel{5}{10}_{\min }$ & \multirow{2}{*}{$\begin{array}{l}48 \text { hr } \\
1 \text { hr } \\
27 \text { min } \\
2 \text { min } \\
4 \%\end{array}$} \\
\hline $\begin{array}{l}\text { Average duration } \\
\text { Proportion of time }\end{array}$ & $\frac{1}{2 \%} \min$ & $\begin{array}{l}2 \min \\
7 \%\end{array}$ & $\begin{array}{l}1 \min \\
4 \%\end{array}$ & $\frac{2}{7} \min$ & $\begin{array}{l}2 m \text { min } \\
2 \%\end{array}$ & \\
\hline \multicolumn{7}{|c|}{ Scheduled Meetings } \\
\hline $\begin{array}{l}\text { Number of meetings } \\
\text { Time in meetings }\end{array}$ & $145^{4}$ min & $150^{4} \min$ & $\begin{array}{r}4 \\
35 \\
\text { min }\end{array}$ & 125 min & $345^{4} \min$ & \multirow{2}{*}{$\begin{array}{l}18 \\
13 \mathrm{hr} \\
21 \text { min } \\
45 \text { min } \\
34 \%\end{array}$} \\
\hline $\begin{array}{l}\text { Average duration } \\
\text { Proportion of time }\end{array}$ & $\begin{array}{l}36 \mathrm{~min} \\
28 \%\end{array}$ & $\begin{array}{l}38 \mathrm{~min} \\
35 \%\end{array}$ & $\begin{array}{l}9 \min \\
8 x\end{array}$ & $\begin{array}{l}63 \text { min } \\
33 \%\end{array}$ & $\begin{array}{l}87 \text { min } \\
60 \%\end{array}$ & \\
\hline \multicolumn{7}{|c|}{ Unscheduled Meetings } \\
\hline $\begin{array}{l}\text { Numbers of meetings } \\
\text { Time in meetings }\end{array}$ & 23 min & $\begin{array}{l}14 \\
51 \text { min }\end{array}$ & $32 \mathrm{~min}$ & $\begin{array}{l}16 \\
46 \text { min }\end{array}$ & $\begin{array}{l}12 \\
23 \min \end{array}$ & \multirow{2}{*}{$\begin{array}{l}70 \\
3 \mathrm{hr} \\
44 \cdot \mathrm{min} \\
3 \mathrm{~min} \\
10 \%\end{array}$} \\
\hline $\begin{array}{l}\text { Average duration } \\
\text { Proportion of time }\end{array}$ & $\begin{array}{l}4 \text { min } \\
4 \%\end{array}$ & $\begin{array}{l}4 \min \\
12 \%\end{array}$ & $\begin{array}{l}4 \mathrm{~min} \\
19.0\end{array}$ & $\begin{array}{l}3 \text { min } \\
12 \%\end{array}$ & $\begin{array}{l}2 \mathrm{~min} \\
4: 0\end{array}$ & \\
\hline \multicolumn{7}{|c|}{ Tours } \\
\hline $\begin{array}{l}\text { Number of tours } \\
\text { Titie on tours }\end{array}$ & $\begin{array}{c}8 \\
252 \text { min }\end{array}$ & $\begin{array}{l}11 \\
148 \min \end{array}$ & $\begin{array}{l}10 \\
204 \min \end{array}$ & $\begin{array}{l}10 \\
146 \text { min }\end{array}$ & $\begin{array}{l}10 \\
155 \text { min }\end{array}$ & \multirow{2}{*}{$\begin{array}{r}49 \\
15 \mathrm{hr} \\
6 \text { min } \\
\quad \\
\text { min }\end{array}$} \\
\hline $\begin{array}{l}\text { Average duration } \\
\text { Proportion of time }\end{array}$ & $\begin{array}{l}32 \min \\
49 \%\end{array}$ & $\begin{array}{l}13 \min \\
35 \%\end{array}$ & $\begin{array}{l}20 \min \\
48 \%\end{array}$ & $\begin{array}{l}15 \text { min } \\
39 \%\end{array}$ & $\begin{array}{l}16 \text { min } \\
27 \%\end{array}$ & \\
\hline \multicolumn{7}{|c|}{ Length of Activities } \\
\hline $\begin{array}{l}\text { Proportion of activities lasting iess } \\
\text { than } 9 \text { minutes }\end{array}$ & $55 \%$ & $71 \%$ & $72 \%$ & $74 \%$ & $71 \%$ & $70 \%$ \\
\hline Proportion lasting longer than 60 minutes & $5 \%$ & $4 \%$ & $0 \%$ & $5 \%$ & $6 \%$ & $4 \%$ \\
\hline
\end{tabular}


CHRONOLOGY RECORD

ASSISTANT PRINCIPAL $\# 3$

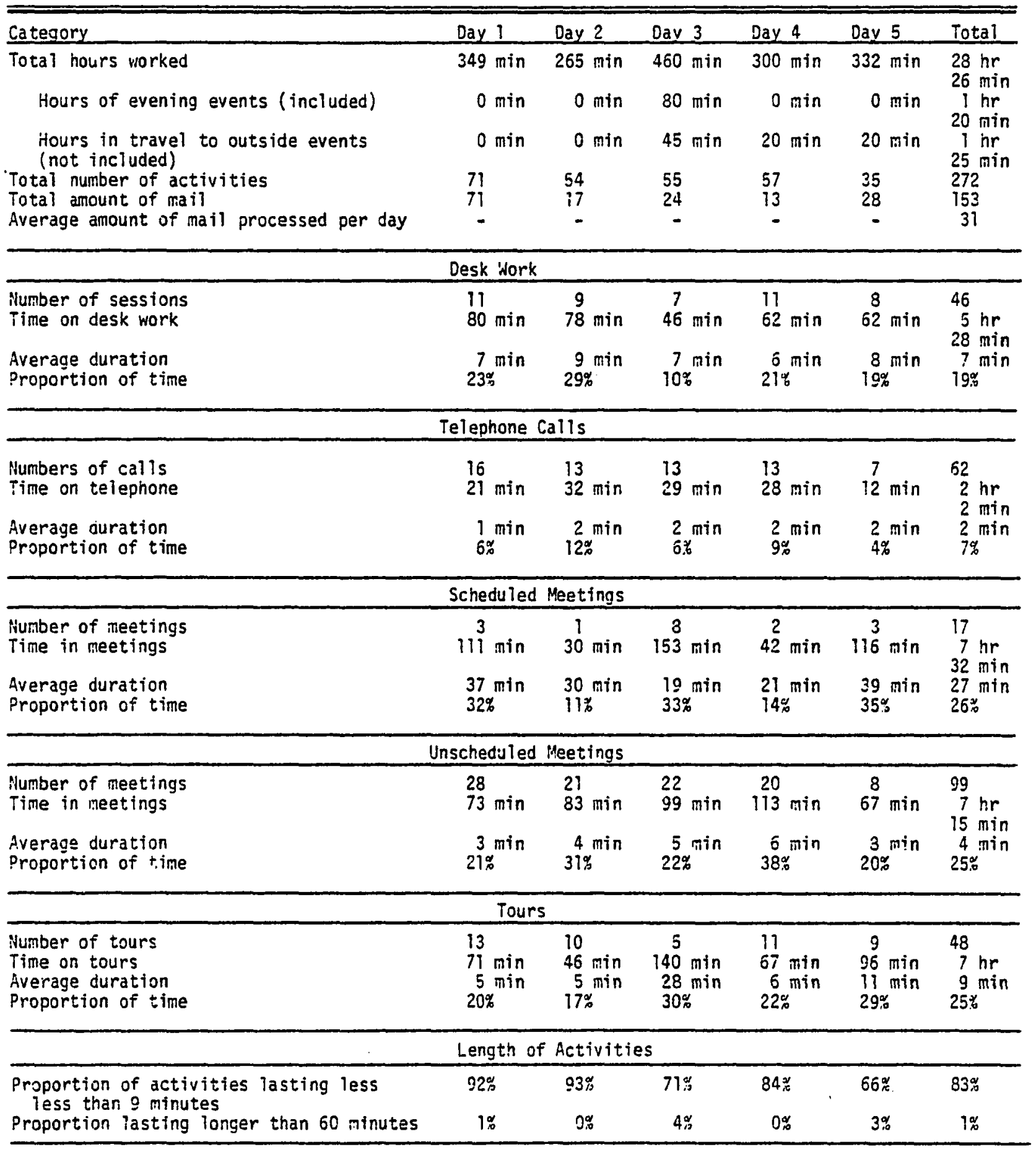


CHRONOLOGY RECORO

ASSISTANT PRIIICIPAL $\$ 4$

\begin{tabular}{|c|c|c|c|c|c|c|}
\hline Category & Day 1 & Day 2 & Dav 3 & Day 4 & Day 5 & Total \\
\hline Total hours worked & $311 \min$ & $345 \min$ & $352 \mathrm{~min}$ & $333 \mathrm{~min}$ & 290 min & 27 hrs \\
\hline $\begin{array}{l}\text { Hours of evening events (included) } \\
\text { Hours in travel to outside events } \\
\text { (not included) }\end{array}$ & $\begin{array}{r}0 \min \\
68 \min \end{array}$ & $\begin{array}{l}0 \text { min } \\
0 \text { min }\end{array}$ & $\begin{array}{l}0 \min \\
0 \text { min }\end{array}$ & 0 min & $\begin{array}{l}0 \text { min } \\
0 \text { min }\end{array}$ & $\begin{array}{l}0 \mathrm{hr} \\
1 \mathrm{hr} \\
8 \mathrm{~min}\end{array}$ \\
\hline $\begin{array}{l}\text { Total number of activities } \\
\text { Total amount of mail }\end{array}$ & $\begin{array}{l}29 \\
23\end{array}$ & $\begin{array}{l}32 \\
40\end{array}$ & $\begin{array}{l}33 \\
16\end{array}$ & $\begin{array}{l}39 \\
49\end{array}$ & $\begin{array}{l}31 \\
22\end{array}$ & $\begin{array}{l}164 \\
150\end{array}$ \\
\hline Average amount of mail processed per day & - & - & - & - & - & 30 \\
\hline \multicolumn{7}{|c|}{ Desk Work } \\
\hline $\begin{array}{l}\text { Number of sessions } \\
\text { Time on desk work }\end{array}$ & $\begin{array}{l}6 \\
82 \\
\text { min }\end{array}$ & 67 min & 61 min & $178 \mathrm{~min}$ & $44 \min$ & \multirow{2}{*}{$\begin{array}{l}33 \\
7 \text { hr } \\
12 \text { min } \\
13 \text { min } \\
26 \%\end{array}$} \\
\hline $\begin{array}{l}\text { Average duration } \\
\text { Proportion of time }\end{array}$ & $\begin{array}{l}14 \min \\
26 \%\end{array}$ & $\begin{array}{l}10 \min \\
19 \%\end{array}$ & ${ }_{17 \%}^{8} \min$ & $\begin{array}{l}20 \mathrm{~min} \\
53 \%\end{array}$ & $\begin{array}{l}15 \min \\
15 \%\end{array}$ & \\
\hline \multicolumn{7}{|c|}{ Telephone Calls } \\
\hline Number of calls & 5 & 4 min & 11 & 7 & 6 & \multirow{2}{*}{$\begin{array}{c}33 \\
1 \mathrm{hr} \\
11 \mathrm{~min} \\
2 \mathrm{~min} \\
4 \%\end{array}$} \\
\hline $\begin{array}{l}\text { Average duration } \\
\text { Proportion of time }\end{array}$ & $\begin{array}{l}2 \min \\
4 \%\end{array}$ & $1 \%$ & $\begin{array}{l}3 \min \\
8 \%\end{array}$ & ${ }_{3 \%}^{2} \min$ & $\begin{array}{l}3 \text { min } \\
5 \%\end{array}$ & \\
\hline \multicolumn{7}{|c|}{ Scheduled Meetings } \\
\hline $\begin{array}{l}\text { Number of meetings } \\
\text { Time in meetings }\end{array}$ & $155^{3} \min$ & $219^{5} \min$ & $150^{4} \min$ & $\begin{array}{l}0 \\
0\end{array}$ & $51 \mathrm{~min}$ & \multirow{2}{*}{$\begin{array}{r}14 \\
9 \mathrm{hr} \\
36 \mathrm{~min} \\
41 \mathrm{~min} \\
35 \%\end{array}$} \\
\hline $\begin{array}{l}\text { Average duration } \\
\text { Proportion of time }\end{array}$ & $\begin{array}{l}52 \mathrm{~min} \\
50 \%\end{array}$ & $\begin{array}{l}44 \text { min } \\
63 \%\end{array}$ & $\begin{array}{l}38 \text { min } \\
43 \%\end{array}$ & $\overline{0 \%}$ & $\begin{array}{l}26 \text { min } \\
13 \%\end{array}$ & \\
\hline \multicolumn{7}{|c|}{ Unscheduled Meetings } \\
\hline $\begin{array}{l}\text { Number of meetings } \\
\text { Time in meetings }\end{array}$ & $45 \mathrm{~min}$ & $\begin{array}{l}10 \\
34 \mathrm{~min}\end{array}$ & $4^{4} \mathrm{~min}$ & $\begin{array}{l}17 \\
59 \text { min }\end{array}$ & $121 \mathrm{~min}$ & \multirow{2}{*}{$\begin{array}{l}53 \\
5 \text { hr } \\
7 \text { min } \\
6 \text { min } \\
19 \%\end{array}$} \\
\hline $\begin{array}{l}\text { Average duration } \\
\text { Proportion of time }\end{array}$ & 5 min & $\begin{array}{l}3 \mathrm{~min} \\
10 \%\end{array}$ & $\begin{array}{l}12 \min \\
14 \%\end{array}$ & ${ }_{18 \%}^{3} \min$ & $\stackrel{9}{42} \min$ & \\
\hline \multicolumn{7}{|c|}{ Tours } \\
\hline $\begin{array}{l}\text { Number of tours } \\
\text { Time on tours }\end{array}$ & 23 min & 28 min & ${ }_{6}^{6} \min$ & $\begin{array}{r}6 \\
92 \mathrm{~min}\end{array}$ & $\begin{array}{l}7 \\
64 \min \end{array}$ & \multirow{2}{*}{$\begin{array}{r}31 \\
4 \mathrm{hr} \\
33 \mathrm{~min} \\
9 \mathrm{~min} \\
17 \%\end{array}$} \\
\hline $\begin{array}{l}\text { Average duration } \\
\text { Proportion of time }\end{array}$ & $4 \min$ & $\begin{array}{l}5 \mathrm{~min} \\
8 \%\end{array}$ & $\begin{array}{l}11 \text { min } \\
19 \%\end{array}$ & $\begin{array}{l}15 \min \\
28 \%\end{array}$ & $22 \%$ & \\
\hline \multicolumn{7}{|c|}{ Length of Activities } \\
\hline $\begin{array}{l}\text { Proportion of activities lasting less } \\
\text { than } 9 \text { minutes }\end{array}$ & $66 \%$ & $72 \%$ & $70 \%$ & $69 \%$ & $52 \%$ & $66 \%$ \\
\hline Proportion lasting longer than 60 minutes & $3 \%$ & $0 \%$ & $0 \%$ & $0 \%$ & $0 \%$ & 18 \\
\hline
\end{tabular}


CHRONOLOGY RECORD

ASSISTANT PRINCIPAL $: 5$

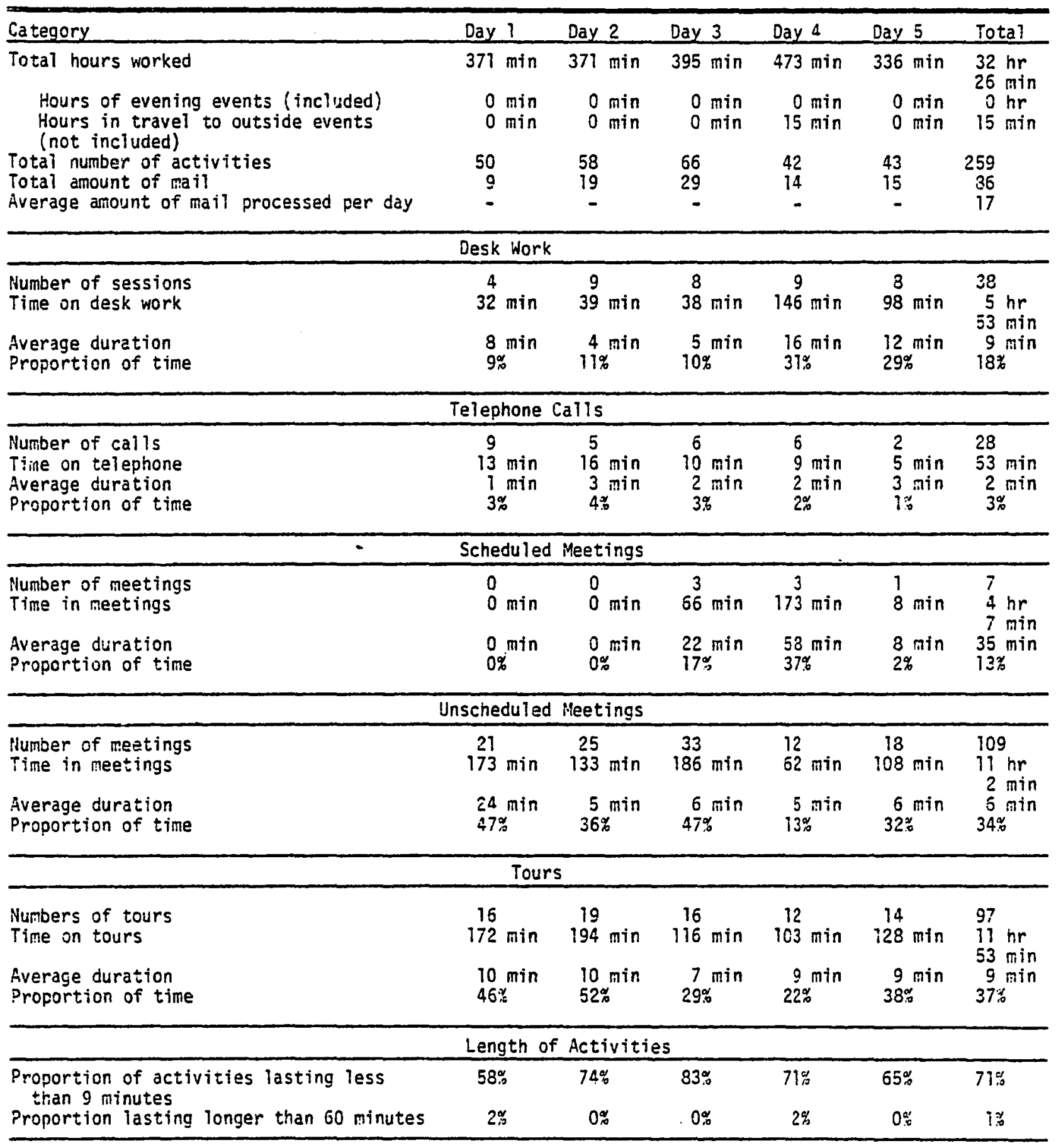


Appendix D

Ma il Input Records 
MAIL RECORD, INPUT

ASSISTANT PRINCIPAL \#T

\begin{tabular}{|c|c|c|c|c|c|c|}
\hline Category & Day 1 & Day 2 & Day 3 & Day 4 & Day 5 & Total \\
\hline Number pieces received & 12 & 14 & 32 & 16 & 6 & 80 \\
\hline \multicolumn{7}{|c|}{ Form of Input } \\
\hline $\begin{array}{l}\text { Note } \\
\text { Form } \\
\text { Memo } \\
\text { Letter } \\
\text { Paper } \\
\text { Report } \\
\text { Brochure } \\
\text { Book } \\
\text { Handbook } \\
\text { Courtesy copy } \\
\text { Newsletter } \\
\text { Periodical } \\
\text { Clipping } \\
\text { Carbon copy of letter, memo, form, or note } \\
\text { Forwarded ietter or memo } \\
\text { Miscellaneous }\end{array}$ & $\begin{array}{r}25 \% \\
42 \% \\
0 \% \\
8 \% \\
0 \% \\
25 \% \\
0 \% \\
0 \% \\
0 \% \\
0 \% \\
0 \% \\
0 \% \\
0 \% \\
0 \% \\
0 \% \\
0 \%\end{array}$ & $\begin{array}{r}0 \% \\
64 \% \\
0 \% \\
7 \% \\
0 \% \\
0 \% \\
0 \% \\
0 \% \\
0 \% \\
14 \% \\
0 \% \\
7 \% \\
0 \% \\
7 \% \\
0 \% \\
0 \%\end{array}$ & $\begin{array}{r}6 \% \\
56 \% \\
9 \% \\
6 \% \\
0 \% \\
16 \% \\
0 \% \\
0 \% \\
0 \% \\
0 \% \\
0 \% \\
3 \% \\
0 \% \\
3 \% \\
0 \% \\
0 \%\end{array}$ & $\begin{array}{r}13 \% \\
6 \% \\
6 \% \\
6 \% \\
0 \% \\
0 \% \\
44 \% \\
0 \% \\
0 \% \\
0 \% \\
6 \% \\
0 \% \\
6 \% \\
0 \% \\
13 \% \\
0 \% \\
0 \%\end{array}$ & $\begin{array}{r}17 \% \\
33 \% \\
0 \% \\
0 \% \\
0 \% \\
50 \% \\
0 \% \\
0 \% \\
0 \% \\
0 \% \\
0 \% \\
0 \% \\
0 \% \\
0 \% \\
0 \% \\
0 \%\end{array}$ & $\begin{array}{r}10 \% \\
44 \% \\
5 \% \\
6 \% \\
0 \% \\
23 \% \\
0 \% \\
0 \% \\
0 \% \\
0 \% \\
4 \% \\
0 \% \\
4 \% \\
0 \% \\
5 \% \\
0 \% \\
0 \%\end{array}$ \\
\hline \multicolumn{7}{|c|}{ Attention } \\
\hline $\begin{array}{l}\text { Glance } \\
\text { Skin } \\
\text { Read } \\
\text { Study } \\
\text { Write } \\
\text { Proof }\end{array}$ & $\begin{array}{r}8 \% \\
75 \% \\
17 \% \\
0 \% \\
0 \% \\
0 \%\end{array}$ & $\begin{array}{l}21 \% \\
64 \% \\
14 \% \\
0 \% \\
0 \% \\
0 \%\end{array}$ & $\begin{array}{l}63 \% \\
22 \% \\
16 \% \\
0 \% \\
0 \% \\
0 \%\end{array}$ & $\begin{array}{r}31 \% \\
25 \% \\
44 \% \\
0 \% \\
0 \% \\
0 \%\end{array}$ & $\begin{array}{r}17 \% \\
67 \% \\
0 \% \\
0 \% \\
17 \% \\
0 \%\end{array}$ & $\begin{array}{r}38 \% \\
41 \% \\
20 \% \\
0 \% \\
1 \% \\
0 \%\end{array}$ \\
\hline \multicolumn{7}{|c|}{ Sender } \\
\hline $\begin{array}{l}\text { External board } \\
\text { Director } \\
\text { District support } \\
\text { Superior } \\
\text { Subordinate A } \\
\text { Subordinate B } \\
\text { Peer A } \\
\text { Peer B } \\
\text { Peer C } \\
\text { Client } \\
\text { Trade organization } \\
\text { Supplier or associate } \\
\text { Publisher } \\
\text { Government } \\
\text { Independent }\end{array}$ & $\begin{array}{l}0 \% \\
0 \% \\
33 \% \\
25 \% \\
33 \% \\
0 \% \\
0 \% \\
0 \% \\
0 \% \\
0 \% \\
0 \% \\
0 \% \\
0 \% \\
8 \% \\
0 \%\end{array}$ & $\begin{array}{l}0 \% \\
0 \% \\
0 \% \\
21 \% \\
54 \% \\
0 \% \\
7 \% \\
0 \% \\
0 \% \\
7 \% \\
0 \% \\
0 \% \\
0 \% \\
0 \% \\
0 \%\end{array}$ & $\begin{array}{r}0 \% \\
0 \% \\
13 \% \\
3 \% \\
72 \% \\
0 \% \\
3 \% \\
0 \% \\
0 \% \\
3 \% \\
0 \% \\
6 \% \\
0 \% \\
0 \% \\
0 \%\end{array}$ & $\begin{array}{r}0 \% \\
0 \% \\
13 \% \\
5 \% \\
63 \% \\
6 \% \\
0 \% \\
0 \% \\
0 \% \\
0 \% \\
13 \% \\
0 \% \\
0 \% \\
0 \% \\
0 \%\end{array}$ & $\begin{array}{r}0 \% \\
0 \% \\
50 \% \\
0 \% \\
33 \% \\
0 \% \\
0 \% \\
0 \% \\
0 \% \\
17 \% \\
0 \% \\
0 \% \\
0 \% \\
0 \% \\
0 \%\end{array}$ & $\begin{array}{l}0 \% \\
0 \% \\
16 \% \\
10 \% \\
00 \% \\
1 \% \\
3 \% \\
0 \% \\
0 \% \\
4 \% \\
3 \% \\
3 \% \\
0 \% \\
1 \% \\
0 \%\end{array}$ \\
\hline \multicolumn{7}{|c|}{ Purpose of Input Mail } \\
\hline $\begin{array}{l}\text { Acknowledgments } \\
\text { Status requests } \\
\text { Solicitations } \\
\text { Authority requests } \\
\text { Total requests } \\
\text { Reference data } \\
\text { General reports } \\
\text { Periodical news } \\
\text { Events } \\
\text { Reports on operations } \\
\text { Advice on situations } \\
\text { Problems and pressures } \\
\text { idsas } \\
\text { Total information } \\
\text { Total miscellaneous }\end{array}$ & $\begin{array}{r}0 \% \\
0 \% \\
8 \% \\
17 \% \\
25 \% \\
58 \% \\
0 \% \\
0 \% \\
0 \% \\
0 \% \\
0 \% \\
0 \% \\
8 \% \\
8 \% \\
74 \% \\
7 \% \\
0 \%\end{array}$ & $\begin{array}{r}14 \% \\
0 \% \\
0 \% \\
43 \% \\
57 \% \\
36 \% \\
0 \% \\
7 \% \\
0 \% \\
0 \% \\
0 \% \\
0 \% \\
0 \% \\
0 \% \\
43 \% \\
0 \%\end{array}$ & $\begin{array}{r}3 \% \\
0 \% \\
9 \% \\
53 \% \\
65 \% \\
31 \% \\
0 \% \\
3 \% \\
0 \% \\
0 \% \\
0 \% \\
0 \% \\
0 \% \\
3 \% \% \\
0 \%\end{array}$ & $\begin{array}{r}0 \% \\
0 \% \\
6 \% \\
37 \% \\
37 \% \\
38 \% \\
0 \% \\
6 \% \\
0 \% \\
0 \% \\
0 \% \\
19 \% \\
0 \% \\
6 \% \% \\
0 \%\end{array}$ & $\begin{array}{r}17 \% \\
0 \% \\
17 \% \\
0 \% \\
34 \% \\
0 \% \\
50 \% \\
0 \% \\
0 \% \\
0 \% \\
0 \% \\
17 \% \\
0 \% \\
67 \% \\
0 \%\end{array}$ & $\begin{array}{r}5 \% \\
0 \% \\
3 \% \\
38 \% \\
51 \% \\
35 \% \\
4 \% \\
4 \% \\
0 \% \\
0 \% \\
0 \% \\
0 \% \\
6 \% \\
1 \% \\
50 \% \\
0 \%\end{array}$ \\
\hline
\end{tabular}


MAIL RECORD, INPUT

ASSISTANT PRINCIPAL \#2

\begin{tabular}{|c|c|c|c|c|c|c|}
\hline Category & Day 1 & Day 2 & Day 3 & Day 4 & Day 5 & Total \\
\hline Number pieces received & 12 & 8 & 11 & 9 & 9 & 49 \\
\hline \multicolumn{7}{|c|}{ Form of Input } \\
\hline $\begin{array}{l}\text { Note } \\
\text { Form } \\
\text { Memo } \\
\text { Letter } \\
\text { Paper } \\
\text { Report } \\
\text { Brochure } \\
\text { Book } \\
\text { Handbook } \\
\text { Courtesy copy } \\
\text { Newsletter } \\
\text { Periodical } \\
\text { CTipping } \\
\text { Carbon copy of letter, memo, form, or note } \\
\text { Forwarded letter or memo } \\
\text { Miscellaneous }\end{array}$ & $\begin{array}{r}17 \% \\
8 \% \\
17 \% \\
8 \% \\
0 \% \\
8 \% \\
0 \% \\
0 \% \\
8 \% \\
8 \% \\
0 \% \\
17 \% \\
0 \% \\
0 \% \\
0 \% \\
8 \%\end{array}$ & $\begin{array}{r}0 \% \\
0 \% \\
13 \% \\
25 \% \\
0 \% \\
13 \% \\
13 \% \\
0 \% \\
0 \% \\
0 \% \\
25 \% \\
13 \% \\
0 \% \\
0 \% \\
0 \% \\
0 \%\end{array}$ & $\begin{array}{r}9 \% \\
55 \% \\
9 \% \\
9 \% \\
0 \% \\
0 \% \\
0 \% \\
0 \% \\
0 \% \\
0 \% \\
0 \% \\
9 \% \\
0 \% \\
0 \% \\
0 \% \\
9 \%\end{array}$ & $\begin{array}{r}11 \% \\
0 \% \\
0 \% \\
0 \% \\
0 \% \\
0 \% \\
0 \% \\
0 \% \\
0 \% \\
0 \% \\
0 \% \\
44 \% \\
0 \% \\
0 \% \\
33 \% \\
11 \%\end{array}$ & $\begin{array}{r}0 \% \\
22 \% \\
0 \% \\
11 \% \\
0 \% \\
0 \% \\
0 \% \\
0 \% \\
0 \% \\
0 \% \\
0 \% \\
22 \% \\
0 \% \\
22 \% \\
22 \% \\
0 \%\end{array}$ & $\begin{array}{r}8 \% \\
18 \% \\
8 \% \\
10 \% \\
0 \% \\
4 \% \\
2 \% \\
0 \% \\
2 \% \\
2 \% \\
4 \% \\
20 \% \\
0 \% \\
4 \% \\
10 \% \\
6 \%\end{array}$ \\
\hline \multicolumn{7}{|c|}{ Attention } \\
\hline $\begin{array}{l}\text { Glance } \\
\text { Skim } \\
\text { Read } \\
\text { Study. } \\
\text { Write } \\
\text { Proof }\end{array}$ & $\begin{array}{r}58 \% \\
0 \% \\
42 \% \\
0 \% \\
0 \% \\
0 \%\end{array}$ & $\begin{array}{r}0 \% \\
25 \% \\
75 \% \\
0 \% \\
0 \% \\
0 \%\end{array}$ & $\begin{array}{r}9 \% \\
9 \% \\
82 \% \\
0 \% \\
0 \% \\
0 \%\end{array}$ & $\begin{array}{r}75 \% \\
22 \% \\
11 \% \\
0 \% \\
0 \% \\
0 \%\end{array}$ & $\begin{array}{r}22 \% \\
22 \% \\
56 \% \\
0 \% \\
0 \% \\
0 \%\end{array}$ & $\begin{array}{l}33 \% \\
14 \% \\
53 \% \\
0 \% \\
0 \% \\
0 \%\end{array}$ \\
\hline \multicolumn{7}{|c|}{ Sender } \\
\hline $\begin{array}{l}\text { External board } \\
\text { Director } \\
\text { District support } \\
\text { Superior } \\
\text { Subordinate A } \\
\text { Subordinate B } \\
\text { Peer A } \\
\text { Peer B } \\
\text { Peer C } \\
\text { Client } \\
\text { Trade organization } \\
\text { Supplier or assoctate } \\
\text { Publisher } \\
\text { Government } \\
\text { Independent }\end{array}$ & $\begin{array}{r}8 \% \\
0 \% \\
0 \% \\
8 \% \\
50 \% \\
0 \% \\
0 \% \\
0 \% \\
0 \% \\
25 \% \\
0 \% \\
8 \% \\
0 \% \\
0 \% \\
0 \%\end{array}$ & $\begin{array}{r}38 \% \\
0 \% \\
13 \% \\
25 \% \\
0 \% \\
0 \% \\
0 \% \\
0 \% \\
0 \% \\
0 \% \\
25 \% \\
0 \% \\
0 \% \\
0 \% \\
0 \%\end{array}$ & $\begin{array}{l}9 \% \\
0 \% \\
0 \% \\
0 \% \\
73 \% \\
0 \% \\
0 \% \\
0 \% \\
0 \% \\
9 \% \\
0 \% \\
9 \% \\
0 \% \\
0 \% \\
0 \%\end{array}$ & $\begin{array}{r}0 \% \\
0 \% \\
22 \% \\
22 \% \\
33 \% \\
0 \% \\
0 \% \\
0 \% \\
0 \% \\
0 \% \\
0 \% \\
11 \% \\
0 \% \\
11 \% \\
0 \%\end{array}$ & $\begin{array}{r}0 \% \\
0 \% \\
0 \% \\
22 \% \\
33 \% \\
0 \% \\
0 \% \\
0 \% \\
0 \% \\
11 \% \\
11 \% \\
11 \% \\
0 \% \\
11 \% \\
0 \%\end{array}$ & $\begin{array}{r}10 \% \\
0 \% \\
65 \% \\
14 \% \\
41 \% \\
0 \% \\
0 \% \\
0 \% \\
0 \% \\
0 \% \\
10 \% \\
5 \% \\
8 \% \\
0 \% \\
4 \% \\
0 \%\end{array}$ \\
\hline \multicolumn{7}{|c|}{ Purpese of Input Mail } \\
\hline $\begin{array}{l}\text { Acknowledgments } \\
\text { Status requests } \\
\text { Solicitations } \\
\text { Authority requests } \\
\text { Total requests } \\
\text { Reference data } \\
\text { General roports } \\
\text { Periodical news } \\
\text { Events } \\
\text { Reports on operations } \\
\text { Advice on situations } \\
\text { Problems and pressures } \\
\text { Ideas } \\
\text { Total information } \\
\text { iotal mi scellaneous }\end{array}$ & $\begin{array}{r}8 \% \\
25 \% \\
8 \% \\
8 \% \\
49 \% \\
25 \% \\
0 \% \\
17 \% \\
0 \% \\
0 \% \\
0 \% \\
8 \% \\
0 \% \\
50 \% \\
0 \%\end{array}$ & $\begin{array}{r}0 \% \\
0 \% \\
13 \% \\
0 \% \\
13 \% \\
13 \% \\
39 \% \\
38 \% \\
0 \% \\
0 \% \\
0 \% \\
0 \% \\
0 \% \\
89 \% \\
0 \%\end{array}$ & $\begin{array}{r}0 \% \\
0 \% \\
9 \% \\
0 \% \\
9 \% \\
0 \% \\
0 \% \\
0 \% \\
9 \% \\
73 \% \\
0 \% \\
0 \% \\
9 \% \\
0 \% \\
91 \% \\
9 \% \\
0 \%\end{array}$ & $\begin{array}{r}0 \% \\
0 \% \\
0 \% \\
0 \% \\
0 \% \\
33 \% \\
0 \% \\
44 \% \\
17 \% \\
0 \% \\
0 \% \\
11 \% \\
17 \% \\
100 \% \\
0 \%\end{array}$ & $\begin{array}{r}0 \% \\
0 \% \\
22 \% \\
0 \% \\
22 \% \\
11 \% \\
0 \% \\
22 \% \\
11 \% \\
0 \% \\
11 \% \\
11 \% \\
0 \% \\
66 \% \\
11 \%\end{array}$ & $\begin{array}{r}2 \% \\
8 \% \\
10 \% \\
2 \% \\
22 \% \\
15 \% \\
6 \% \\
24 \% \\
20 \% \\
0 \% \\
2 \% \\
3 \% \\
0 \% \\
76 \% \\
2 \% \\
2 \%\end{array}$ \\
\hline
\end{tabular}


MAIL RECORO, INPUT

ASSISTANT PRINCIPAL \#3

\begin{tabular}{|c|c|c|c|c|c|c|}
\hline Category & Day 1 & Day 2 & Day 3 & Day 4 & Day 5 & Total \\
\hline Number pieces received & 60 & 6 & 12 & 5 & 20 & 103 \\
\hline \multicolumn{7}{|c|}{ Form of Input } \\
\hline $\begin{array}{l}\text { Note } \\
\text { Form } \\
\text { Memo } \\
\text { Letter } \\
\text { Paper } \\
\text { Report } \\
\text { Brochure } \\
\text { Book } \\
\text { Handbook } \\
\text { Courtesy copy } \\
\text { Newsletter } \\
\text { Periodical } \\
\text { Clipping } \\
\text { Carbon copy of letter, memo, form, or note } \\
\text { Forwarded letter or memo } \\
\text { Miscellaneous }\end{array}$ & $\begin{array}{r}7 \% \\
23 \% \\
0 \% \\
0 \% \\
0 \% \\
2 \% \\
0 \% \\
0 \% \\
0 \% \\
0 \% \\
0 \% \\
0 \% \\
0 \% \\
68 \% \\
0 \% \\
0 \%\end{array}$ & $\begin{array}{r}0 \% \\
83 \% \\
0 \% \\
0 \% \\
0 \% \\
0 \% \\
0 \% \\
0 \% \\
0 \% \\
0 \% \\
0 \% \\
0 \% \\
0 \% \\
17 \% \\
0 \% \\
0 \%\end{array}$ & $\begin{array}{r}17 \% \\
50 \% \\
0 \% \\
0 \% \\
0 \% \\
0 \% \\
0 \% \\
0 \% \\
0 \% \\
0 \% \\
0 \% \\
0 \% \\
0 \% \\
17 \% \\
0 \% \\
17 \%\end{array}$ & $\begin{array}{r}0 \% \\
100 \% \\
0 \% \\
0 \% \\
0 \% \\
0 \% \\
0 \% \\
0 \% \\
0 \% \\
0 \% \\
0 \% \\
0 \% \\
0 \% \\
0 \% \\
0 \% \\
0 \% \\
0 \%\end{array}$ & $\begin{array}{r}0 \% \\
30 \% \\
25 \% \\
5 \% \\
0 \% \\
0 \% \\
0 \% \\
0 \% \\
0 \% \\
5 \% \\
5 \% \\
5 \% \\
0 \% \\
0 \% \\
5 \% \\
0 \% \\
25 \% \\
\% \\
\% \\
\% \\
\% \\
\% \\
\% \\
\end{array}$ & $\begin{array}{r}6 \% \\
35 \% \\
5 \% \\
1 \% \\
0 \% \\
1 \% \\
1 \% \\
0 \% \\
0 \% \\
0 \% \\
1 \% \\
1 \% \\
0 \% \\
0 \% \\
0 \% \\
44 \% \\
0 \% \\
7 \%\end{array}$ \\
\hline \multicolumn{7}{|c|}{ Attention } \\
\hline $\begin{array}{l}\text { Glance } \\
\text { Skim } \\
\text { Read } \\
\text { Study } \\
\text { Write } \\
\text { Proof }\end{array}$ & $\begin{array}{r}68 \% \\
8 \% \\
22 \% \\
2 \% \\
0 \% \\
0 \%\end{array}$ & $\begin{array}{l}17 \% \\
17 \% \\
67 \% \\
0 \% \\
0 \% \\
0 \%\end{array}$ & $\begin{array}{r}0 \% \\
0 \% \\
100 \% \\
0 \% \\
0 \% \\
0 \%\end{array}$ & $\begin{array}{r}0 \% \\
0 \% \\
100 \% \\
0 \% \\
0 \% \\
0 \%\end{array}$ & $\begin{array}{r}15 \% \\
30 \% \\
50 \% \\
0 \% \\
0 \% \\
5 \%\end{array}$ & $\begin{array}{r}44 \% \\
12 \% \\
43 \% \\
1 \% \\
1 \% \\
0 \% \\
1 \%\end{array}$ \\
\hline \multicolumn{7}{|c|}{ Sender } \\
\hline $\begin{array}{l}\text { External board } \\
\text { Director } \\
\text { District support } \\
\text { Superior } \\
\text { Subordinate A } \\
\text { Subordinate B } \\
\text { Peer A } \\
\text { Peer B } \\
\text { Peer C } \\
\text { Client } \\
\text { Trade organization } \\
\text { Supplier or associate } \\
\text { Publisher } \\
\text { Government } \\
\text { Independent }\end{array}$ & $\begin{array}{l}0 \% \\
0 \% \\
0 \% \\
0 \% \\
0 \% \\
10 \% \\
0 \% \\
0 \% \\
0 \% \\
0 \% \\
0 \% \\
0 \% \\
0 \% \\
0 \% \\
0 \% \\
0 \%\end{array}$ & $\begin{array}{r}0 \% \\
0 \% \\
0 \% \\
0 \% \\
100 \% \\
0 \% \\
0 \% \\
0 \% \\
0 \% \\
0 \% \\
0 \% \\
0 \% \\
0 \% \\
0 \% \\
0 \% \\
0 \%\end{array}$ & $\begin{array}{l}0 \% \\
0 \% \\
0 \% \\
8 \% \\
92 \% \\
0 \% \\
0 \% \\
0 \% \\
0 \% \\
0 \% \\
0 \% \\
0 \% \\
0 \% \\
0 \% \\
0 \% \\
0 \%\end{array}$ & $\begin{array}{l}0 \% \\
0 \% \\
0 \% \\
0 \% \\
100 \% \\
0 \% \\
0 \% \\
0 \% \\
0 \% \\
0 \% \\
0 \% \\
0 \% \\
0 \% \\
0 \% \\
0 \% \\
0 \%\end{array}$ & $\begin{array}{r}0 \% \\
0 \% \\
15 \% \\
10 \% \\
60 \% \\
0 \% \\
0 \% \\
0 \% \\
0 \% \\
5 \% \\
10 \% \\
0 \% \\
0 \% \\
0 \% \\
0 \%\end{array}$ & $\begin{array}{r}0 \% \\
0 \% \\
3 \% \\
3 \% \\
3 \% \\
91 \% \\
0 \% \\
0 \% \\
0 \% \\
0 \% \\
1 \% \\
2 \% \\
0 \% \\
0 \% \\
0 \% \\
0 \% \\
0 \%\end{array}$ \\
\hline \multicolumn{7}{|c|}{ Purpose of Input Mail } \\
\hline $\begin{array}{l}\text { Acknowledgments } \\
\text { Status requests } \\
\text { Solicitations } \\
\text { Authority requests } \\
\text { Totai requests } \\
\text { Reference data } \\
\text { General reports } \\
\text { Periodical news } \\
\text { Events } \\
\text { Reports on operations } \\
\text { Advice on situations } \\
\text { Problems and pressures } \\
\text { Ideas } \\
\text { Total information } \\
\text { Total miscellaneous }\end{array}$ & $\begin{array}{r}0 \% \\
2 \% \\
0 \% \\
17 \% \\
19 \% \\
80 \% \\
0 \% \\
0 \% \\
0 \% \\
0 \% \\
0 \% \\
2 \% \\
0 \% \\
82 \% \\
0 \%\end{array}$ & $\begin{array}{l}0 \% \\
0 \% \\
0 \% \\
17 \% \\
17 \% \\
17 \% \\
0 \% \\
0 \% \\
0 \% \\
0 \% \\
0 \% \\
67 \% \\
0 \% \\
84 \% \\
0 \%\end{array}$ & $\begin{array}{r}0 \% \\
0 \% \\
0 \% \\
67 \% \\
67 \% \\
33 \% \\
0 \% \\
0 \% \\
0 \% \\
0 \% \\
0 \% \\
0 \% \\
0 \% \\
33 \% \\
0 \%\end{array}$ & $\begin{array}{r}0 \% \\
0 \% \\
0 \% \\
80 \% \\
80 \% \\
0 \% \\
0 \% \\
0 \% \\
0 \% \\
0 \% \\
0 \% \\
0 \% \\
20 \% \\
0 \% \\
20 \% \\
0 \%\end{array}$ & $\begin{array}{r}0 \% \\
10 \% \\
15 \% \\
10 \% \\
35 \% \\
30 \% \\
0 \% \\
5 \% \\
10 \% \\
0 \% \\
0 \% \\
20 \% \\
0 \% \\
65 \% \\
0 \%\end{array}$ & $\begin{array}{r}0 \% \\
3 \% \\
3 \% \\
24 \% \\
30 \% \\
57 \% \\
0 \% \\
1 \% \\
2 \% \\
0 \% \\
0 \% \\
0 \% \\
70 \% \\
0 \% \\
70 \% \\
0 \%\end{array}$ \\
\hline
\end{tabular}


MAIL RECORD, INPUT

ASSISTANT PRINCIPAL $\# 4$

\begin{tabular}{|c|c|c|c|c|c|c|}
\hline Category & Day 1 & Day 2 & Day 3 & Day 4 & Day 5 & Total \\
\hline Number pieces received & 20 & 31 & 13 & 33 & 16 & 113 \\
\hline \multicolumn{7}{|c|}{ Form of Input } \\
\hline $\begin{array}{l}\text { Note } \\
\text { Form } \\
\text { Memo } \\
\text { Letter } \\
\text { Paper } \\
\text { Report } \\
\text { Brochure } \\
\text { Book } \\
\text { Handbook } \\
\text { Courtesy copy } \\
\text { Newsletter } \\
\text { Periodical } \\
\text { Clipping } \\
\text { Carbon copy of letter, memo, form, or note } \\
\text { Forwarded letter or memo } \\
\text { Miscellaneous }\end{array}$ & $\begin{array}{r}15 \% \\
25 \% \\
10 \% \\
0 \% \\
0 \% \\
5 \% \\
5 \% \\
0 \% \\
0 \% \\
20 \% \\
10 \% \\
0 \% \\
0 \% \\
0 \% \\
0 \% \\
10 \%\end{array}$ & $\begin{array}{r}19 \% \\
32 \% \\
10 \% \\
3 \% \\
0 \% \\
0 \% \\
0 \% \\
0 \% \\
0 \% \\
10 \% \\
3 \% \\
3 \% \\
0 \% \\
0 \% \\
0 \% \\
19 \%\end{array}$ & $\begin{array}{r}31 \% \\
8 \% \\
15 \% \\
8 \% \\
8 \% \\
0 \% \\
0 \% \\
8 \% \\
0 \% \\
0 \% \\
0 \% \\
0 \% \\
8 \% \\
0 \% \\
0 \% \\
8 \% \\
8 \%\end{array}$ & $\begin{array}{r}3 \% \\
27 \% \\
15 \% \\
9 \% \\
0 \% \\
0 \% \\
6 \% \\
3 \% \\
3 \% \\
3 \% \\
3 \% \\
6 \% \\
0 \% \\
9 \% \\
0 \% \\
12 \%\end{array}$ & $\begin{array}{r}13 \% \\
38 \% \\
13 \% \\
0 \% \\
0 \% \\
0 \% \\
0 \% \\
0 \% \\
0 \% \\
0 \% \\
0 \% \\
6 \% \\
13 \% \\
0 \% \\
0 \% \\
6 \% \\
13 \%\end{array}$ & $\begin{array}{r}14 \% \\
27 \% \\
12 \% \\
4 \% \\
1 \% \\
1 \% \\
4 \% \\
1 \% \\
1 \% \\
7 \% \\
7 \% \\
4 \% \\
5 \% \\
0 \% \\
2 \% \\
2 \% \\
2 \% \\
13 \%\end{array}$ \\
\hline \multicolumn{7}{|c|}{ Attention } \\
\hline $\begin{array}{l}\text { Glance } \\
\text { Skim } \\
\text { Read } \\
\text { Study } \\
\text { Write } \\
\text { Proof }\end{array}$ & $\begin{array}{r}30 \% \\
40 \% \\
25 \% \\
5 \% \\
0 \% \\
0 \%\end{array}$ & $\begin{array}{l}29 \% \\
16 \% \\
55 \% \\
0 \% \\
0 \% \\
0 \%\end{array}$ & $\begin{array}{r}23 \% \\
8 \% \\
69 \% \\
0 \% \\
0 \% \\
0 \%\end{array}$ & $\begin{array}{r}27 \% \\
48 \% \\
24 \% \\
0 \% \\
0 \% \\
0 \%\end{array}$ & $\begin{array}{r}13 \% \\
25 \% \\
63 \% \\
0 \% \\
0 \% \\
0 \%\end{array}$ & $\begin{array}{r}26 \% \\
30 \% \\
43 \% \\
1 \% \\
0 \% \\
0 \%\end{array}$ \\
\hline \multicolumn{7}{|c|}{ Sender } \\
\hline $\begin{array}{l}\text { External board } \\
\text { Director } \\
\text { District support } \\
\text { Superior } \\
\text { Subordinate A } \\
\text { Subordinate B } \\
\text { Peer A } \\
\text { Peer } 8 \\
\text { Peer } C \\
\text { Client } \\
\text { Trade organization } \\
\text { Supplier or associate } \\
\text { Publisher } \\
\text { Government } \\
\text { Independent }\end{array}$ & $\begin{array}{r}0 \% \\
0 \% \\
10 \% \\
0 \% \\
45 \% \\
0 \% \\
10 \% \\
10 \% \\
0 \% \\
5 \% \\
15 \% \\
5 \% \\
0 \% \\
0 \% \\
0 \%\end{array}$ & $\begin{array}{r}0 \% \\
0 \% \\
6 \% \\
10 \% \\
65 \% \\
0 \% \\
0 \% \\
0 \% \\
0 \% \\
3 \% \\
13 \% \\
0 \% \\
0 \% \\
0 \% \\
3 \%\end{array}$ & $\begin{array}{r}0 \% \\
0 \% \\
3 \% \\
8 \% \\
46 \% \\
0 \% \\
15 \% \\
0 \% \\
0 \% \\
8 \% \\
0 \% \\
15 \% \\
0 \% \\
0 \% \\
0 \%\end{array}$ & $\begin{array}{r}0 \% \\
0 \% \\
12 \% \\
12 \% \\
39 \% \\
0 \% \\
3 \% \\
0 \% \\
0 \% \\
0 \% \\
27 \% \\
9 \% \\
0 \% \\
0 \% \\
0 \%\end{array}$ & $\begin{array}{l}0 \% \\
0 \% \\
19 \% \\
13 \% \\
63 \% \\
0 \% \\
0 \% \\
0 \% \\
0 \% \\
0 \% \\
6 \% \\
0 \% \\
0 \% \\
0 \% \\
0 \%\end{array}$ & $\begin{array}{r}0 \% \\
0 \% \\
11 \% \\
9 \% \\
5 \% \\
0 \% \\
4 \% \\
2 \% \\
0 \% \\
3 \% \\
15 \% \\
5 \% \\
0 \% \\
0 \% \\
1 \%\end{array}$ \\
\hline \multicolumn{7}{|c|}{ Purpose of Input Mail } \\
\hline $\begin{array}{l}\text { Acknowl edgments } \\
\text { Status requests } \\
\text { Solicitations } \\
\text { Authority requests } \\
\text { Total requests } \\
\text { Reference data } \\
\text { General repcrts } \\
\text { Feriodical news } \\
\text { Events } \\
\text { Reports on operations } \\
\text { Advice on situations } \\
\text { Problems and pressures } \\
\text { ldeas } \\
\text { Total information } \\
\text { Total miscellaneous }\end{array}$ & $\begin{array}{r}0 \% \\
5 \% \\
15 \% \\
5 \% \\
25 \% \\
50 \% \\
0 \% \\
5 \% \\
15 \% \\
0 \% \\
5 \% \\
0 \% \\
0 \% \\
75 \% \\
0 \%\end{array}$ & $\begin{array}{r}10 \% \\
3 \% \\
10 \% \\
32 \% \\
55 \% \\
32 \% \\
0 \% \\
3 \% \\
10 \% \\
0 \% \\
0 \% \\
0 \% \\
0 \% \\
45 \% \\
0 \%\end{array}$ & $\begin{array}{r}23 \% \\
8 \% \\
8 \% \\
0 \% \\
39 \% \\
38 \% \\
0 \% \\
8 \% \\
0 \% \\
0 \% \\
0 \% \\
0 \% \\
15 \% \\
61 \% \\
0 \%\end{array}$ & $\begin{array}{r}3 \% \\
0 \% \\
27 \% \\
12 \% \\
42 \% \\
36 \% \\
0 \% \\
9 \% \\
6 \% \\
0 \% \\
0 \% \\
0 \% \\
6 \% \\
57 \% \\
0 \%\end{array}$ & $\begin{array}{r}0 \% \\
0 \% \\
0 \% \\
38 \% \\
38 \% \\
37 \% \\
6 \% \\
19 \% \\
0 \% \\
0 \% \\
6 \% \\
0 \% \\
0 \% \\
62 \% \\
0 \%\end{array}$ & $\begin{array}{r}6 \% \\
3 \% \\
14 \% \\
18 \% \\
47 \% \\
37 \% \\
1 \% \\
8 \% \\
7 \% \\
7 \% \\
0 \% \\
2 \% \\
0 \% \\
4 \% \\
59 \% \\
0 \%\end{array}$ \\
\hline
\end{tabular}


MAIL RECORD, INPUT

ASSISTANT PRINCIPAL \#5

\begin{tabular}{|c|c|c|c|c|c|c|}
\hline Category & Day 1 & Day 2 & Day 3 & Day 4 & Day 5 & Total \\
\hline Number pieces received & 8 & .13 & 17 & 10 & 6 & 54 \\
\hline \multicolumn{7}{|c|}{ Form of Input } \\
\hline $\begin{array}{l}\text { Note } \\
\text { Form } \\
\text { Memo } \\
\text { Letter } \\
\text { Paper } \\
\text { Report } \\
\text { Brochure } \\
\text { Book } \\
\text { Handbook } \\
\text { Courtesy copy } \\
\text { Hewsletter } \\
\text { Periodical } \\
\text { Clipping } \\
\text { Carbon copy of letter, memo, form, or note } \\
\text { Forwarded letter or memo } \\
\text { Miscellaneous }\end{array}$ & $\begin{array}{r}25 \% \\
25 \% \\
0 \% \\
0 \% \\
0 \% \\
13 \% \\
0 \% \\
0 \% \\
0 \% \\
13 \% \\
0 \% \\
25 \% \\
0 \% \\
0 \% \\
0 \% \\
0 \%\end{array}$ & $\begin{array}{l}0 \% \\
46 \% \\
0 \% \\
0 \% \\
0 \% \\
0 \% \\
8 \% \\
0 \% \\
8 \% \\
15 \% \\
8 \% \\
8 \% \\
0 \% \\
0 \% \\
8 \% \\
0 \%\end{array}$ & $\begin{array}{r}6 \% \\
59 \% \\
12 \% \\
0 \% \\
0 \% \\
0 \% \\
0 \% \\
0 \% \\
0 \% \\
0 \% \\
0 \% \\
0 \% \\
6 \% \\
0 \% \\
0 \% \\
0 \% \\
18 \%\end{array}$ & $\begin{array}{r}0 \% \\
30 \% \\
50 \% \\
0 \% \\
0 \% \\
0 \% \\
0 \% \\
0 \% \\
0 \% \\
0 \% \\
0 \% \\
0 \% \\
0 \% \\
0 \% \\
0 \% \\
20 \%\end{array}$ & $\begin{array}{r}17 \% \\
33 \% \\
0 \% \\
0 \% \\
0 \% \\
0 \% \\
0 \% \\
0 \% \\
0 \% \\
0 \% \\
0 \% \\
0 \% \\
17 \% \\
0 \% \\
17 \% \\
0 \% \\
17 \%\end{array}$ & $\begin{array}{r}7 \% \\
43 \% \\
13 \% \\
0 \% \\
0 \% \\
2 \% \\
2 \% \\
2 \% \\
0 \% \\
2 \% \\
6 \% \\
2 \% \\
9 \% \\
9 \% \\
0 \% \\
2 \% \\
2 \% \\
11 \%\end{array}$ \\
\hline \multicolumn{7}{|c|}{ Attention } \\
\hline $\begin{array}{l}\text { Glance } \\
\text { Skim } \\
\text { Read } \\
\text { Study } \\
\text { Write } \\
\text { Proof }\end{array}$ & $\begin{array}{r}38 \% \\
13 \% \\
50 \% \\
0 \% \\
0 \% \\
0 \%\end{array}$ & $\begin{array}{r}46 \% \\
8 \% \\
46 \% \\
0 \% \\
0 \% \\
0 \%\end{array}$ & $\begin{array}{r}18 \% \\
29 \% \\
53 \% \\
0 \% \\
0 \% \\
0 \%\end{array}$ & $\begin{array}{r}40 \% \\
30 \% \\
30 \% \\
0 \% \\
0 \% \\
0 \%\end{array}$ & $\begin{array}{r}33 \% \\
17 \% \\
50 \% \\
0 \% \\
0 \% \\
0 \%\end{array}$ & $\begin{array}{r}33 \% \\
20 \% \\
46 \% \\
0 \% \\
0 \% \\
0 \%\end{array}$ \\
\hline \multicolumn{7}{|c|}{ Sender } \\
\hline \multirow[t]{2}{*}{$\begin{array}{l}\text { External board } \\
\text { Director } \\
\text { District support } \\
\text { Superior } \\
\text { Subordinate A } \\
\text { Subordinate B } \\
\text { Peer A } \\
\text { Peer B } \\
\text { Peer C } \\
\text { Client } \\
\text { Trade organization } \\
\text { Supplier or associate } \\
\text { Publisher } \\
\text { Government } \\
\text { Independent }\end{array}$} & $\begin{array}{r}0 \% \\
0 \% \\
0 \% \\
0 \% \\
75 \% \\
0 \% \\
0 \% \\
0 \% \\
0 \% \\
0 \% \\
13 \% \\
0 \% \\
0 \% \\
0 \% \\
0 \% \\
13 \%\end{array}$ & $\begin{array}{r}0 \% \\
0 \% \\
0 \% \\
23 \% \\
38 \% \\
0 \% \\
0 \% \\
15 \% \\
0 \% \\
8 \% \\
0 \% \\
8 \% \\
0 \% \\
8 \% \\
0 \%\end{array}$ & $\begin{array}{r}0 \% \\
0 \% \\
6 \% \\
\tilde{0} \% \\
88 \% \\
0 \% \\
0 \% \\
0 \% \\
0 \% \\
6 \% \\
0 \% \\
0 \% \\
0 \% \\
0 \% \\
0 \%\end{array}$ & $\begin{array}{r}0 \% \\
0 \% \\
0 \% \\
0 \% \\
50 \% \\
50 \% \\
0 \% \\
0 \% \\
10 \% \\
0 \% \\
0 \% \\
0 \% \\
0 \% \\
0 \% \\
0 \% \\
0 \%\end{array}$ & $\begin{array}{r}0 \% \\
0 \% \\
17 \% \\
0 \% \\
83 \% \\
0 \% \\
0 \% \\
0 \% \\
0 \% \\
0 \% \\
0 \% \\
0 \% \\
0 \% \\
0 \% \\
0 \% \\
0 \%\end{array}$ & $\begin{array}{r}0 \% \\
0 \% \\
4 \% \\
13 \% \\
67 \% \\
0 \% \\
0 \% \\
6 \% \\
0 \% \\
6 \% \\
0 \% \\
0 \% \\
2 \% \\
0 \% \\
2 \% \\
2 \%\end{array}$ \\
\hline & pose of & put $\mathrm{Mail}$ & & & & \\
\hline $\begin{array}{l}\text { Acknowl edgments } \\
\text { Status requests } \\
\text { Solicitations } \\
\text { Authority requests } \\
\text { Total requests } \\
\text { Reference data } \\
\text { General reports } \\
\text { Periodical news } \\
\text { Events } \\
\text { Reports on operations } \\
\text { Advice on situations } \\
\text { Probiems and pressures } \\
\text { Ideas } \\
\text { Total information } \\
\text { Total miscellaneous }\end{array}$ & $\begin{array}{r}13 \% \\
0 \% \\
0 \% \\
0 \% \\
13 \% \\
38 \% \\
0 \% \\
25 \% \\
0 \% \\
0 \% \\
0 \% \\
25 \% \\
0 \% \\
88 \% \\
0 \%\end{array}$ & $\begin{array}{r}0 \% \\
0 \% \\
8 \% \\
23 \% \\
37 \% \\
46 \% \\
0 \% \\
15 \% \\
0 \% \\
0 \% \\
0 \% \\
8 \% \\
0 \% \\
69 \% \\
0 \%\end{array}$ & $\begin{array}{r}0 \% \\
0 \% \\
0 \% \\
12 \% \\
12 \% \\
35 \% \\
0 \% \\
6 \% \\
0 \% \\
0 \% \\
0 \% \\
47 \% \\
0 \% \\
88 \% \\
0 \%\end{array}$ & $\begin{array}{r}0 \% \\
0 \% \\
0 \% \\
0 \% \\
0 \% \\
90 \% \\
0 \% \\
0 \% \\
0 \% \\
0 \% \\
0 \% \\
20 \% \\
0 \% \\
100 \% \\
0 \%\end{array}$ & $\begin{array}{r}0 \% \\
0 \% \\
0 \% \\
0 \% \\
0 \% \\
50 \% \\
0 \% \\
17 \% \\
0 \% \\
0 \% \\
0 \% \\
33 \% \\
0 \% \\
100 \% \\
0 \%\end{array}$ & $\begin{array}{r}2 \% \\
0 \% \\
2 \% \\
9 \% \\
9 \% \\
13 \% \\
45 \% \\
0 \% \\
11 \% \\
0 \% \\
0 \% \\
0 \% \\
28 \% \\
0 \% \\
87 \% \\
0 \%\end{array}$ \\
\hline
\end{tabular}


Appendix E

Mail Output Records 
MAIL RECORO, OUTPUT

ASSISTANT PRIIICIPAL \#1

\begin{tabular}{|c|c|c|c|c|c|c|}
\hline Catesory & Day 1 & Day 2 & Dav 3 & Day 4 & Day 5 & Total \\
\hline $\begin{array}{l}\text { Number reactions to inputs } \\
\text { Number self-initiated } \\
\text { Total output } \\
\text { Output as percent of input } \\
\text { Self-initiated as percent of output }\end{array}$ & $\begin{array}{c}5 \\
4 \\
9 \\
75 \% \\
44 \%\end{array}$ & $\begin{array}{c}1 \\
5 \\
6 \\
43 \% \\
83 \%\end{array}$ & $\begin{array}{c}5 \\
4 \\
9 \\
28 \% \\
44 \%\end{array}$ & $\begin{array}{l}5 \\
7 \\
12 \\
75 \% \\
58 \%\end{array}$ & $\begin{array}{c}2 \\
8 \\
10 \\
167 \% \\
30 \%\end{array}$ & $\begin{array}{l}18 \\
28 \\
46 \\
58 \% \\
61 \%\end{array}$ \\
\hline \multicolumn{7}{|c|}{ Form of Output Mail } \\
\hline $\begin{array}{l}\text { Note } \\
\text { Form } \\
\text { Memo } \\
\text { Letter } \\
\text { Paper } \\
\text { Report } \\
\text { Brochure } \\
\text { Book } \\
\text { Handbook } \\
\text { Courtesy copy } \\
\text { Newsletter } \\
\text { Pertodical } \\
\text { Clipping } \\
\text { Carbon copy of letter, memo, or note } \\
\text { Forwarded items } \\
\text { Miscellaneous }\end{array}$ & $\begin{array}{r}11 \% \\
11 \% \\
33 \% \\
11 \% \\
0 \% \\
33 \% \\
0 \% \\
0 \% \\
0 \% \\
0 \% \\
0 \% \\
0 \% \\
0 \% \\
0 \% \\
0 \% \\
0 \%\end{array}$ & $\begin{array}{r}0 \% \\
67 \% \\
0 \% \\
33 \% \\
0 \% \\
0 \% \\
0 \% \\
0 \% \\
0 \% \\
0 \% \\
0 \% \\
0 \% \\
0 \% \\
0 \% \\
0 \% \\
0 \%\end{array}$ & $\begin{array}{r}0 \% \\
67 \% \\
22 \% \\
0 \% \\
0 \% \\
11 \% \\
0 \% \\
0 \% \\
0 \% \\
0 \% \\
0 \% \\
0 \% \\
0 \% \\
0 \% \\
0 \% \\
0 \%\end{array}$ & $\begin{array}{r}25 \% \\
50 \% \\
8 \% \\
8 \% \\
0 \% \\
0 \% \\
0 \% \\
0 \% \\
0 \% \\
8 \% \\
0 \% \\
0 \% \\
0 \% \\
0 \% \\
0 \% \\
0 \% \\
0 \% \\
0 \%\end{array}$ & $\begin{array}{r}0 \% \\
50 \% \\
10 \% \\
20 \% \\
0 \% \\
0 \% \\
0 \% \\
0 \% \\
0 \% \\
0 \% \\
0 \% \\
0 \% \\
0 \% \\
0 \% \\
0 \% \\
20 \% \\
0 \% \\
0 \%\end{array}$ & $\begin{array}{r}9 \% \\
48 \% \\
15 \% \\
13 \% \\
13 \% \\
0 \% \\
9 \% \\
0 \% \\
0 \% \\
2 \% \\
2 \% \\
0 \% \\
0 \% \\
0 \% \\
0 \% \\
0 \% \\
4 \% \\
0 \% \\
0 \%\end{array}$ \\
\hline \multicolumn{7}{|c|}{ Target of Output Mail } \\
\hline $\begin{array}{l}\text { External board } \\
\text { Director } \\
\text { District support } \\
\text { Superior } \\
\text { Subordinate A } \\
\text { Subordinate B } \\
\text { Peer A } \\
\text { Peer B } \\
\text { Peer C } \\
\text { Client. } \\
\text { Trade orzanization } \\
\text { Supplier or associate } \\
\text { Publisher } \\
\text { Government } \\
\text { Independent }\end{array}$ & $\begin{array}{r}0 \% \\
0 \% \\
0 \% \\
0 \% \\
56 \% \\
0 \% \\
11 \% \\
22 \% \\
0 \% \\
11 \% \\
0 \% \\
0 \% \\
0 \% \\
0 \% \\
0 \%\end{array}$ & $\begin{array}{r}0 \% \\
0 \% \\
0 \% \\
0 \% \\
83 \% \\
0 \% \\
0 \% \\
0 \% \\
0 \% \\
17 \% \\
0 \% \\
0 \% \\
0 \% \\
0 \% \\
0 \%\end{array}$ & $\begin{array}{r}0 \% \\
0 \% \\
11 \% \\
0 \% \\
56 \% \\
0 \% \\
22 \% \\
0 \% \\
0 \% \\
11 \% \\
0 \% \\
0 \% \\
0 \% \\
0 \% \\
11 \%\end{array}$ & $\begin{array}{l}0 \% \\
0 \% \\
0 \% \\
0 \% \\
92 \% \\
0 \% \\
0 \% \\
0 \% \\
0 \% \\
0 \% \\
0 \% \\
0 \% \\
0 \% \\
0 \% \\
0 \% \\
0 \%\end{array}$ & $\begin{array}{r}0 \% \\
0 \% \\
20 \% \\
0 \% \\
50 \% \\
0 \% \\
0 \% \\
0 \% \\
0 \% \\
30 \% \\
0 \% \\
0 \% \\
0 \% \\
0 \% \\
0 \%\end{array}$ & $\begin{array}{l}0 \% \\
0 \% \\
7 \% \\
0 \% \\
6 \% \\
0 \% \\
0 \% \\
7 \% \\
4 \% \\
0 \% \\
15 \% \\
0 \% \\
0 \% \\
0 \% \\
0 \% \\
0 \% \\
2 \%\end{array}$ \\
\hline \multicolumn{7}{|c|}{ Purpose of Output iail } \\
\hline $\begin{array}{l}\text { Acknowledge input } \\
\text { 'Arite to third party re: input, decision, } \\
\text { situation } \\
\text { Reply to information received } \\
\text { Forward information to subordinate } \\
\text { Reply to written request } \\
\text { Forward request to subordinate } \\
\text { Acknowledge or repiy to verbal contact } \\
\text { Arite report } \\
\text { Originate note, letter, or memo } \\
\text { Originate miscellaneous } \\
\text { Forward to non-subordinate }\end{array}$ & $\begin{array}{r}0 \% \\
0 \% \\
0 \% \\
0 \% \\
22 \% \\
11 \% \\
0 \% \\
0 \% \\
0 \% \\
33 \% \\
33 \% \\
0 \%\end{array}$ & $\begin{array}{r}0 \% \\
0 \% \\
0 \% \\
0 \% \\
17 \% \\
0 \% \\
17 \% \\
0 \% \\
0 \% \\
17 \% \\
50 \% \\
0 \%\end{array}$ & $\begin{array}{r}0 \% \\
0 \% \\
0 \% \\
22 \% \\
11 \% \\
0 \% \\
0 \% \\
0 \% \\
0 \% \\
67 \% \\
0 \%\end{array}$ & $\begin{array}{r}0 \% \\
0 \% \\
17 \% \\
3 \% \\
0 \% \\
0 \% \\
0 \% \\
0 \% \\
33 \% \\
42 \% \\
0 \%\end{array}$ & $\begin{array}{r}0 \% \\
0 \% \\
0 \% \\
0 \% \\
0 \% \\
10 \% \\
0 \% \\
10 \% \\
0 \% \\
0 \% \\
40 \% \\
40 \% \\
0 \%\end{array}$ & $\begin{array}{r}0 \% \\
0 \% \\
4 \% \\
4 \% \\
15 \% \\
7 \% \\
2 \% \\
2 \% \\
2 \% \\
0 \% \\
26 \% \\
46 \% \\
0 \%\end{array}$ \\
\hline
\end{tabular}


MAIL RECORD, OUTPUT

ASSISTANT PRIHCIPAL $\$ 2$

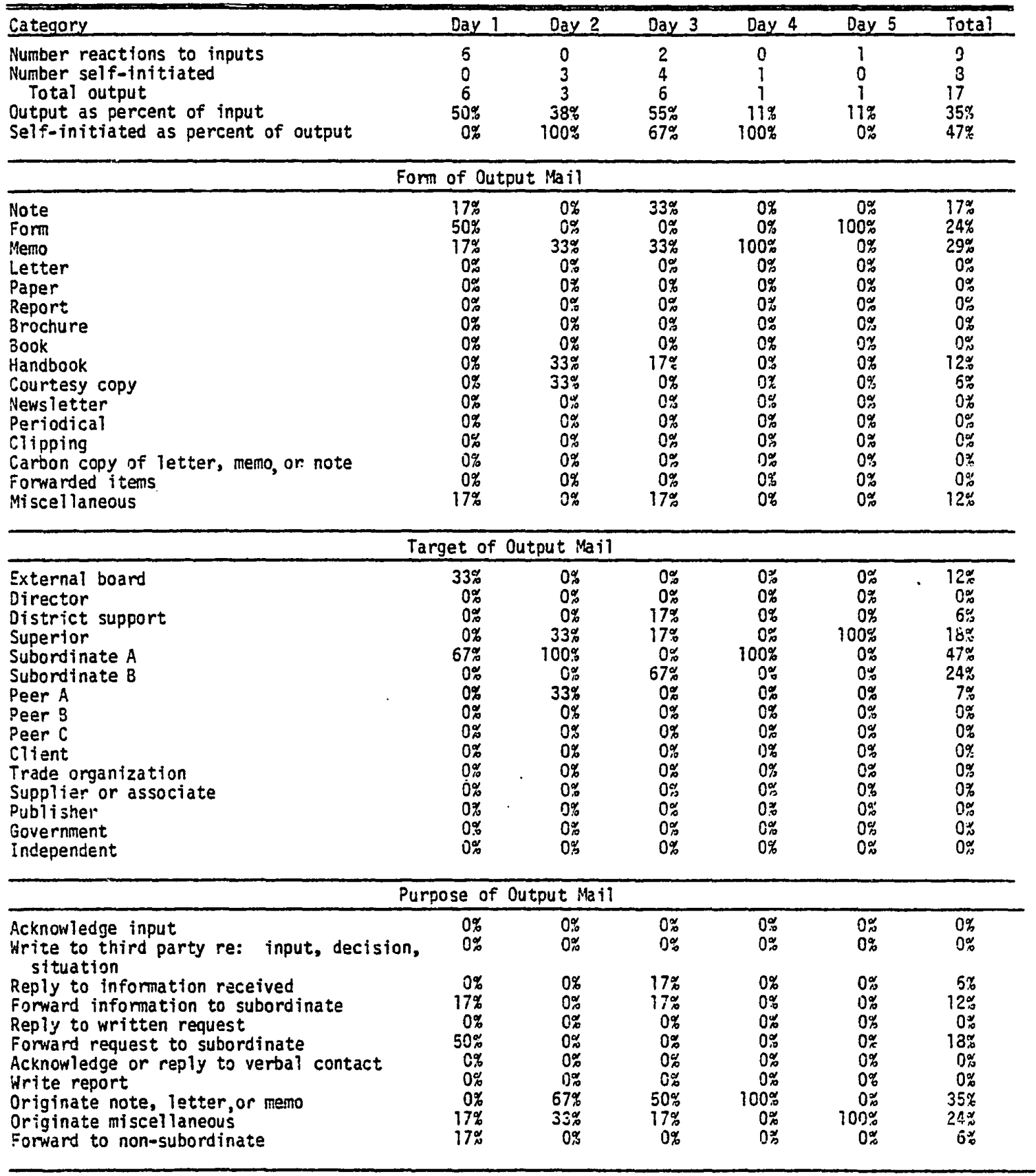


MAIL RECORD, OUTPUT

ASSISTANT PRIMCIPAL \#3

\begin{tabular}{|c|c|c|c|c|c|c|}
\hline Category & Day 1 & Day 2 & Day 3 & Day 4 & Day 5 & Total \\
\hline $\begin{array}{l}\text { Number reactions to inputs } \\
\text { Number self-initiated } \\
\text { Total output } \\
\text { Output as percent of input } \\
\text { Self-initiated as percent of output }\end{array}$ & $\begin{array}{l}3 \\
8 \\
11 \\
18 \% \\
73 \%\end{array}$ & $\begin{array}{c}7 \\
4 \\
11 \\
183 \% \\
36 \%\end{array}$ & $\begin{array}{r}11 \\
7 \\
12 \\
100 \% \\
8 \%\end{array}$ & $\begin{array}{r}5 \\
3 \\
8 \\
160 \% \\
38 \%\end{array}$ & $\begin{array}{c}5 \\
3 \\
8 \\
40 \% \\
38 \%\end{array}$ & $\begin{array}{l}31 \\
19 \\
50 \\
49 \% \\
38 \%\end{array}$ \\
\hline \multicolumn{7}{|c|}{ Form of Output Mail } \\
\hline $\begin{array}{l}\text { Note } \\
\text { Form } \\
\text { Memo } \\
\text { Letter } \\
\text { Paper } \\
\text { Report } \\
\text { Brochure } \\
\text { Book } \\
\text { Handbook } \\
\text { Courtesy copy } \\
\text { Newsletter } \\
\text { Periodical } \\
\text { Clipping } \\
\text { Carbon copy of letter, memo, or note } \\
\text { Forwarded items } \\
\text { Miscellaneous }\end{array}$ & $\begin{array}{r}0 \% \\
64 \% \\
0 \% \\
36 \% \\
0 \% \\
0 \% \\
0 \% \\
0 \% \\
0 \% \\
0 \% \\
0 \% \\
0 \% \\
0 \% \\
0 \% \\
0 \% \\
0 \%\end{array}$ & $\begin{array}{r}18 \% \\
55 \% \\
0 \% \\
27 \% \\
0 \% \\
0 \% \\
0 \% \\
0 \% \\
0 \% \\
0 \% \\
0 \% \\
0 \% \\
0 \% \\
0 \% \\
0 \% \\
0 \%\end{array}$ & $\begin{array}{r}8 \% \\
58 \% \\
0 \% \\
33 \% \\
0 \% \\
0 \% \\
0 \% \\
0 \% \\
0 \% \\
0 \% \\
0 \% \\
0 \% \\
0 \% \\
0 \% \\
0 \% \\
0 \% \\
0 \%\end{array}$ & $\begin{array}{r}0 \% \\
75 \% \\
0 \% \\
13 \% \\
0 \% \\
0 \% \\
0 \% \\
0 \% \\
0 \% \\
13 \% \\
0 \% \\
0 \% \\
0 \% \\
0 \% \\
0 \% \\
0 \% \\
0 \%\end{array}$ & $\begin{array}{r}0 \% \\
88 \% \\
0 \% \\
0 \% \\
0 \% \\
0 \% \\
0 \% \\
0 \% \\
0 \% \\
0 \% \\
0 \% \\
0 \% \\
0 \% \\
0 \% \\
0 \% \\
0 \% \\
0 \% \\
13 \%\end{array}$ & $\begin{array}{r}6 \% \\
66 \% \\
0 \% \\
24 \% \\
0 \% \\
0 \% \\
0 \% \\
0 \% \\
0 \% \\
2 \% \\
0 \% \\
0 \% \\
0 \% \\
0 \% \\
0 \% \\
0 \% \\
0 \% \\
2 \% \\
2 \%\end{array}$ \\
\hline \multicolumn{7}{|c|}{ Target of Output Mail } \\
\hline $\begin{array}{l}\text { External board } \\
\text { Oirector } \\
\text { District support } \\
\text { Superior } \\
\text { Subordinate A } \\
\text { Subordinate B } \\
\text { Peer A } \\
\text { Peer B } \\
\text { Peer C } \\
\text { Client } \\
\text { Trade organization } \\
\text { Supplier or associate } \\
\text { Pubijsher } \\
\text { Government } \\
\text { Independent }\end{array}$ & $\begin{array}{r}0 \% \\
0 \% \\
0 \% \\
0 \% \\
73 \% \\
0 \% \\
0 \% \\
0 \% \\
0 \% \\
36 \% \\
0 \% \\
0 \% \\
0 \% \\
0 \% \\
0 \%\end{array}$ & $\begin{array}{r}0 \% \\
0 \% \\
0 \% \\
0 \% \\
02 \% \\
0 \% \\
0 \% \\
0 \% \\
0 \% \\
0 \% \\
18 \% \\
0 \% \\
0 \% \\
0 \% \\
0 \% \\
0 \%\end{array}$ & $\begin{array}{l}0 \% \\
0 \% \\
0 \% \\
0 \% \\
67 \% \\
0 \% \\
0 \% \\
0 \% \\
0 \% \\
33 \% \\
0 \% \\
0 \% \\
0 \% \\
0 \% \\
0 \%\end{array}$ & $\begin{array}{l}0 \% \\
0 \% \\
0 \% \\
0 \% \\
75 \% \\
0 \% \\
0 \% \\
0 \% \\
0 \% \\
13 \% \\
0 \% \\
13 \% \\
0 \% \\
0 \% \\
0 \%\end{array}$ & $\begin{array}{r}0 \% \\
0 \% \\
0 \% \\
0 \% \\
100 \% \\
0 \% \\
0 \% \\
0 \% \\
0 \% \\
13 \% \\
0 \% \\
0 \% \\
0 \% \\
0 \% \\
0 \% \\
0 \%\end{array}$ & $\begin{array}{r}0 \% \\
0 \% \\
0 \% \\
0 \% \\
78 \% \\
0 \% \\
0 \% \\
0 \% \\
0 \% \\
0 \% \\
24 \% \\
0 \% \\
2 \% \\
0 \% \\
0 \% \\
0 \%\end{array}$ \\
\hline \multicolumn{7}{|c|}{ Purpose of Output Mail } \\
\hline $\begin{array}{l}\text { Acknowledge input } \\
\text { Write to third party re: input, decision, } \\
\text { situation } \\
\text { Reply to information received } \\
\text { Forward information to subordinate } \\
\text { Reply to written request } \\
\text { Forward request to subordinate } \\
\text { Acknowledge or reply to verbal contact } \\
\text { Write report } \\
\text { Originate note, letter, or memo } \\
\text { Originate miscellaneous } \\
\text { Forward to non-subordinate }\end{array}$ & $\begin{array}{r}0 \% \\
0 \% \\
9 \% \\
0 \% \\
18 \% \\
0 \% \\
0 \% \\
0 \% \\
36 \% \\
36 \% \\
0 \%\end{array}$ & $\begin{array}{r}0 \% \\
0 \% \\
45 \% \\
0 \% \\
0 \% \\
0 \% \\
0 \% \\
0 \% \\
27 \% \\
27 \% \\
0 \%\end{array}$ & $\begin{array}{r}0 \% \\
0 \% \\
8 \% \\
0 \% \\
50 \% \\
0 \% \\
0 \% \\
0 \% \\
33 \% \\
3 \% \\
0 \%\end{array}$ & $\begin{array}{r}0 \% \\
0 \% \\
0 \% \\
0 \% \\
0 \% \\
50 \% \\
0 \% \\
13 \% \\
0 \% \\
13 \% \\
25 \% \\
0 \%\end{array}$ & $\begin{array}{r}0 \% \\
0 \% \\
0 \% \\
38 \% \\
0 \% \\
13 \% \\
0 \% \\
0 \% \\
0 \% \\
0 \% \\
50 \% \\
0 \%\end{array}$ & $\begin{array}{r}0 \% \\
0 \% \\
0 \% \\
20 \% \\
0 \% \\
26 \% \\
0 \% \\
2 \% \\
2 \% \\
0 \% \\
24 \% \\
28 \% \\
0 \%\end{array}$ \\
\hline
\end{tabular}


MAIL RECORD, OUTPUT

ASSISTANT PRINCIPAL $\# 4$

\begin{tabular}{|c|c|c|c|c|c|c|}
\hline Category & Day 1 & Day 2 & Day 3 & Day 4 & Day 5 & Total \\
\hline $\begin{array}{l}\text { Number reactions to inputs } \\
\text { Number self-initiated } \\
\text { Total output } \\
\text { Output as percent of input } \\
\text { Seif-initiated as percent of output }\end{array}$ & $\begin{array}{l}1 \\
2 \\
3 \\
15 \% \\
67 \%\end{array}$ & $\begin{array}{c}4 \\
5 \\
9 \\
29 \% \\
56 \%\end{array}$ & $\begin{array}{c}0 \\
3 \\
3 \\
23 \% \\
100 \%\end{array}$ & $\begin{array}{l}14 \\
2 \\
16 \\
48 \% \\
13 \%\end{array}$ & $\begin{array}{r}6 \\
0 \\
6 \\
38 \% \\
0 \%\end{array}$ & $\begin{array}{l}25 \\
12 \\
37 \\
33 \% \\
32 \%\end{array}$ \\
\hline \multicolumn{7}{|c|}{ Form of Output inail } \\
\hline $\begin{array}{l}\text { Note } \\
\text { Form } \\
\text { Hemo } \\
\text { Letter } \\
\text { Paper } \\
\text { Report } \\
\text { Brochure } \\
\text { Book } \\
\text { Handbook } \\
\text { Courtesy copy } \\
\text { Newsletter } \\
\text { Periodical } \\
\text { Clipping } \\
\text { Carbon copy of letter, memo, or note } \\
\text { Forwarded itens } \\
\text { Miscellaneous }\end{array}$ & $\begin{array}{r}33 \% \\
33 \% \\
33 \% \\
0 \% \\
0 \% \\
0 \% \\
0 \% \\
0 \% \\
0 \% \\
0 \% \\
0 \% \\
0 \% \\
0 \% \\
0 \% \\
0 \% \\
0 \%\end{array}$ & $\begin{array}{r}67 \% \\
0 \% \\
11 \% \\
11 \% \\
0 \% \\
0 \% \\
0 \% \\
0 \% \\
0 \% \\
0 \% \\
0 \% \\
0 \% \\
0 \% \\
0 \% \\
11 \% \\
0 \%\end{array}$ & $\begin{array}{r}100 \% \\
0 \% \\
0 \% \\
0 \% \\
0 \% \\
0 \% \\
0 \% \\
0 \% \\
0 \% \\
0 \% \\
0 \% \\
0 \% \\
0 \% \\
0 \% \\
0 \% \\
0 \%\end{array}$ & $\begin{array}{r}0 \% \\
38 \% \\
0 \% \\
0 \% \\
0 \% \\
0 \% \\
0 \% \\
0 \% \\
0 \% \\
0 \% \\
0 \% \\
0 \% \\
0 \% \\
0 \% \\
63 \% \\
0 \%\end{array}$ & 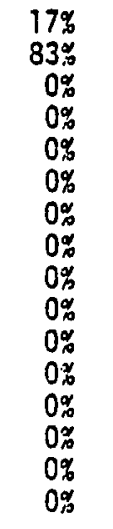 & $\begin{array}{r}30 \% \\
32 \% \\
5 \% \\
3 \% \\
0 \% \\
0 \% \\
0 \% \\
0 \% \\
0 \% \\
0 \% \\
0 \% \\
0 \% \\
0 \% \\
0 \% \\
0 \% \\
30 \% \\
0 \%\end{array}$ \\
\hline \multicolumn{7}{|c|}{ Target of Output Mail } \\
\hline $\begin{array}{l}\text { External board } \\
\text { Director } \\
\text { District support } \\
\text { Superior } \\
\text { Subordinate A } \\
\text { Subordinate B } \\
\text { Peer A } \\
\text { Peer B } \\
\text { Peer C } \\
\text { Client } \\
\text { Trade organization } \\
\text { Supplier or associate } \\
\text { Publisher } \\
\text { dovernment } \\
\text { Independent }\end{array}$ & $\begin{array}{r}0 \% \\
0 \% \\
0 \% \\
0 \% \\
67 \% \\
0 \% \\
0 \% \\
0 \% \\
0 \% \\
0 \% \\
33 \% \\
0 \% \\
0 \% \\
0 \% \\
0 \%\end{array}$ & $\begin{array}{r}0 \% \\
0 \% \\
0 \% \\
11 \% \\
100 \% \\
0 \% \\
11 \% \\
0 \% \\
0 \% \\
0 \% \\
0 \% \\
0 \% \\
0 \% \\
0 \% \\
0 \%\end{array}$ & $\begin{array}{r}0 \% \\
0 \% \\
0 \% \\
0 \% \\
100 \% \\
0 \% \\
0 \% \\
0 \% \\
0 \% \\
0 \% \\
0 \% \\
0 \% \\
0 \% \\
0 \% \\
0 \%\end{array}$ & $\begin{array}{l}0 \% \\
0 \% \\
6 \% \\
6 \% \\
88 \% \\
0 \% \\
0 \% \\
0 \% \\
0 \% \\
0 \% \\
0 \% \\
6 \% \\
0 \% \\
0 \% \\
0 \%\end{array}$ & $\begin{array}{r}0 \% \\
0 \% \\
0 \% \\
0 \% \\
100 \% \\
0 \% \\
0 \% \\
0 \% \\
0 \% \\
0 \% \\
0 \% \\
0 \% \\
0 \% \\
0 \% \\
0 \%\end{array}$ & $\begin{array}{l}0 \% \\
0 \% \\
3 \% \\
5 \% \\
92 \% \\
0 \% \\
0 \% \\
0 \% \\
0 \% \\
0 \% \\
3 \% \\
3 \% \\
0 \% \\
0 \% \\
0 \%\end{array}$ \\
\hline \multicolumn{7}{|c|}{ Purpose of Output :hail } \\
\hline $\begin{array}{l}\text { Acknowledge input } \\
\text { Write to third party re: input, decision, } \\
\text { situation }\end{array}$ & $\begin{array}{l}0 \% \\
0 \%\end{array}$ & $\begin{array}{l}0 \% \\
0 \%\end{array}$ & $\begin{array}{l}0 \% \\
0 \%\end{array}$ & $\begin{array}{l}0 \% \\
0 \%\end{array}$ & $\begin{array}{l}0 \% \\
0 \%\end{array}$ & $\begin{array}{l}0 \% \\
0 \%\end{array}$ \\
\hline $\begin{array}{l}\text { Reply to information received } \\
\text { Forward information to subordinate } \\
\text { Reply to written request } \\
\text { Forward request to subordinate } \\
\text { Acknowledge or reply to verbal contact } \\
\text { irite report } \\
\text { Originate nota, letter, or memo } \\
\text { Originate miscel ianeous } \\
\text { Forward to non-subordinate }\end{array}$ & $\begin{array}{r}0 \% \\
0 \% \\
33 \% \\
0 \% \\
33 \% \\
0 \% \\
33 \% \\
0 \% \\
0 \%\end{array}$ & $\begin{array}{r}11 \% \\
0 \% \\
0 \% \\
33 \% \\
44 \% \\
0 \% \\
11 \% \\
0 \% \\
0 \%\end{array}$ & $\begin{array}{r}0 \% \\
0 \% \\
0 \% \\
0 \% \\
6 \% \% \\
0 \% \\
0 \% \\
33 \% \\
0 \% \\
0 \%\end{array}$ & $\begin{array}{r}0 \% \\
56 \% \\
i 9 \% \\
6 \% \\
0 \% \\
19 \% \\
0 \% \\
0 \% \\
0 \%\end{array}$ & $\begin{array}{r}0 \% \\
0 \% \\
100 \% \\
0 \% \\
0 \% \\
0 \% \\
0 \% \\
0 \% \\
0 \%\end{array}$ & $\begin{array}{r}3 \% \\
24 \% \\
27 \% \\
11 \% \\
19 \% \\
8 \% \\
8 \% \\
8 \% \\
0 \% \\
0 \%\end{array}$ \\
\hline
\end{tabular}


MAIL RECORD, OUTPUT

ASSISTANT PRINCIPAL \#5

\begin{tabular}{|c|c|c|c|c|c|c|}
\hline Category & Day 1 & Day 2 & Day 3 & Day 4 & Day 5 & Total \\
\hline $\begin{array}{l}\text { Number reactions to inputs } \\
\text { Number self-initiated } \\
\text { Total output } \\
\text { Output as percent of input } \\
\text { Self-initiated as percent of output }\end{array}$ & $\begin{array}{c}0 \\
1 \\
1 \\
13 \% \\
100 \%\end{array}$ & $\begin{array}{l}3 \\
3 \\
6 \\
46 \% \\
50 \%\end{array}$ & $\begin{array}{l}2 \\
10 \\
12 \\
71 \% \\
83 \%\end{array}$ & $\begin{array}{c}2 \\
2 \\
4 \\
40 \% \\
50 \%\end{array}$ & $\begin{array}{c}5 \\
4 \\
9 \\
150 \% \\
44 \%\end{array}$ & $\begin{array}{l}12 \\
20 \\
32 \\
59 \% \\
63 \%\end{array}$ \\
\hline \multicolumn{7}{|c|}{ Form of Output Mail } \\
\hline $\begin{array}{l}\text { Note } \\
\text { Form } \\
\text { ilemo } \\
\text { Letter } \\
\text { Paper } \\
\text { Report } \\
\text { Brochure } \\
\text { Book } \\
\text { Handbook } \\
\text { Courtesy copy } \\
\text { Newsletter } \\
\text { Periodical } \\
\text { Clipping } \\
\text { Carton copy of letter, memo, or note } \\
\text { Forwarded itens } \\
\text { Miscellaneous }\end{array}$ & $\begin{array}{r}0 \% \\
100 \% \\
0 \% \\
0 \% \\
0 \% \\
0 \% \\
0 \% \\
0 \% \\
0 \% \\
0 \% \\
0 \% \\
0 \% \\
0 \% \\
0 \% \\
0 \% \\
0 \%\end{array}$ & $\begin{array}{r}0 \% \\
100 \% \\
0 \% \\
0 \% \\
0 \% \\
0 \% \\
0 \% \\
0 \% \\
0 \% \\
0 \% \\
0 \% \\
0 \% \\
0 \% \\
0 \% \\
0 \% \\
0 \%\end{array}$ & $\begin{array}{r}8 \% \\
92 \% \\
0 \% \\
0 \% \\
0 \% \\
0 \% \\
0 \% \\
0 \% \\
0 \% \\
0 \% \\
0 \% \\
0 \% \\
0 \% \\
0 \% \\
0 \% \\
0 \%\end{array}$ & $\begin{array}{r}0 \% \\
50 \% \\
50 \% \\
0 \% \\
0 \% \\
0 \% \\
0 \% \\
0 \% \\
0 \% \\
0 \% \\
0 \% \\
0 \% \\
0 \% \\
0 \% \\
0 \% \\
0 \%\end{array}$ & $\begin{array}{r}22 \% \\
56 \% \\
0 \% \\
11 \% \\
0 \% \\
0 \% \\
0 \% \\
0 \% \\
0 \% \\
0 \% \\
0 \% \\
0 \% \\
0 \% \\
0 \% \\
0 \% \\
11 \% \\
0 \% \\
\% \\
\% \\
\end{array}$ & $\begin{array}{r}9 \% \\
78 \% \\
6 \% \\
3 \% \\
0 \% \\
0 \% \\
0 \% \\
0 \% \\
0 \% \\
0 \% \\
0 \% \\
0 \% \\
0 \% \\
0 \% \\
0 \% \\
0 \% \\
0 \% \\
3 \% \\
3 \%\end{array}$ \\
\hline \multicolumn{7}{|c|}{ Target of Output Mefl } \\
\hline $\begin{array}{l}\text { External board } \\
\text { Director } \\
\text { District support } \\
\text { Superior } \\
\text { Subordinate A } \\
\text { Subordinate B } \\
\text { Peer A } \\
\text { Peer B } \\
\text { Peer C } \\
\text { Client } \\
\text { Trade organization } \\
\text { Supplier or associate } \\
\text { Publisher } \\
\text { Government } \\
\text { independent }\end{array}$ & $\begin{array}{r}0 \% \\
0 \% \\
0 \% \\
0 \% \\
100 \% \\
0 \% \\
0 \% \\
0 \% \\
0 \% \\
0 \% \\
0 \% \\
0 \% \\
0 \% \\
0 \% \\
0 \%\end{array}$ & $\begin{array}{r}0 \% \\
0 \% \\
0 \% \\
0 \% \\
100 \% \\
0 \% \\
0 \% \\
0 \% \\
0 \% \\
0 \% \\
0 \% \\
0 \% \\
0 \% \\
0 \% \\
0 \%\end{array}$ & $\begin{array}{r}0 \% \\
0 \% \\
0 \% \\
0 \% \\
100 \% \\
0 \% \\
0 \% \\
0 \% \\
0 \% \\
0 \% \\
0 \% \\
0 \% \\
0 \% \\
0 \% \\
0 \%\end{array}$ & $\begin{array}{r}0 \% \\
0 \% \\
0 \% \\
0 \% \\
100 \% \\
0 \% \\
0 \% \\
0 \% \\
0 \% \\
0 \% \\
0 \% \\
0 \% \\
0 \% \\
0 \% \\
0 \%\end{array}$ & $\begin{array}{r}0 \% \\
0 \% \\
0 \% \\
0 \% \\
100 \% \\
0 \% \\
0 \% \\
0 \% \\
0 \% \\
0 \% \\
0 \% \\
0 \% \\
0 \% \\
0 \% \\
0 \%\end{array}$ & $\begin{array}{r}0 \% \\
0 \% \\
0 \% \\
0 \% \\
100 \% \\
0 \% \\
0 \% \\
0 \% \\
0 \% \\
0 \% \\
0 \% \\
0 \% \\
0 \% \\
0 \% \\
0 \% \\
0 \%\end{array}$ \\
\hline \multicolumn{7}{|c|}{ Purpose of Output Mail } \\
\hline $\begin{array}{l}\text { Acknowledge input } \\
\text { Write to third party re: input, decision, } \\
\text { situation }\end{array}$ & $\begin{array}{l}0 \% \\
0 \%\end{array}$ & $\begin{array}{l}0 \% \\
0 \%\end{array}$ & $\begin{array}{l}0 \% \\
0 \%\end{array}$ & $\begin{array}{l}0 \% \\
0 \%\end{array}$ & $\begin{array}{l}0 \% \\
0 \%\end{array}$ & $\begin{array}{l}0 \% \\
0 \%\end{array}$ \\
\hline $\begin{array}{l}\text { Reply to information received } \\
\text { Forward information to subordinate } \\
\text { Reply to written request } \\
\text { Forward request to subordinate } \\
\text { Acknowledge or reply to verbal contact } \\
\text { Write report } \\
\text { Originate note, letter, or memo } \\
\text { Originate miscel laneous } \\
\text { Forward to non-subordinate }\end{array}$ & $\begin{array}{r}0 \% \\
0 \% \\
0 \% \\
0 \% \\
0 \% \\
0 \% \\
0 \% \\
100 \% \\
0 \%\end{array}$ & $\begin{array}{r}33 \% \\
0 \% \\
17 \% \\
0 \% \\
0 \% \\
0 \% \\
0 \% \\
50 \% \\
0 \%\end{array}$ & $\begin{array}{l}8 \% \\
0 \% \\
8 \% \\
0 \% \\
0 \% \\
0 \% \\
8 \% \\
75 \% \\
0 \%\end{array}$ & $\begin{array}{r}C \% \\
25 \% \\
0 \% \\
0 \% \\
0 \% \\
0 \% \\
0 \% \\
75 \% \\
0 \%\end{array}$ & $\begin{array}{r}0 \% \\
11 \% \\
0 \% \\
44 \% \\
0 \% \\
0 \% \\
0 \% \\
44 \% \\
0 \%\end{array}$ & $\begin{array}{r}9 \% \\
6 \% \\
6 \% \\
13 \% \\
0 \% \\
0 \% \\
3 \% \\
63 \% \\
0 \%\end{array}$ \\
\hline
\end{tabular}


Appendix $F$

Contact Records 
APPEINDIX $F(T)$

CONTACT RECORD

ASSISTANT PRINCIPAL \#1

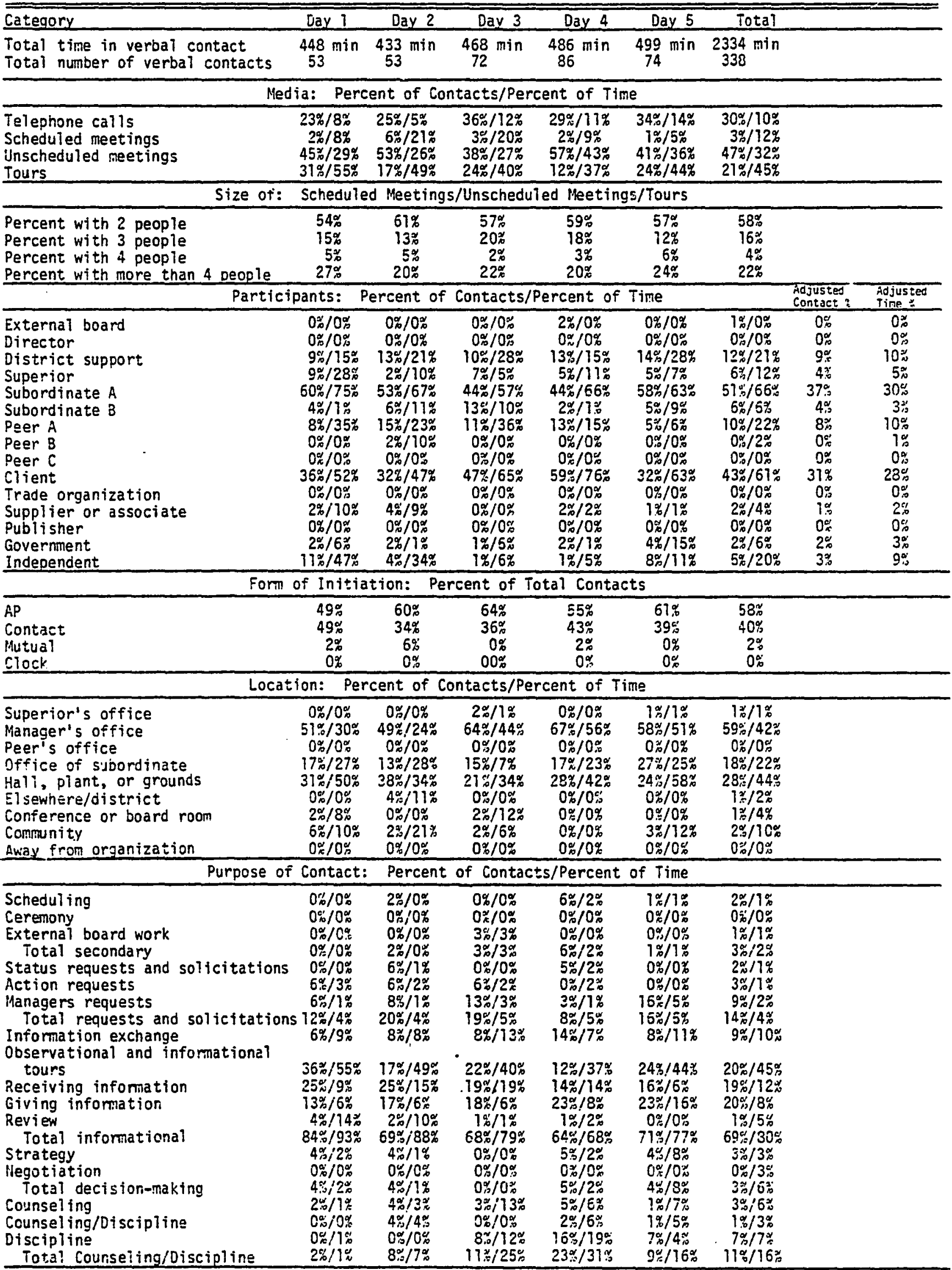


APPENDIX $F(2)$

CONTACT RECORD

ASSISTANT PRINCIPAL \#2

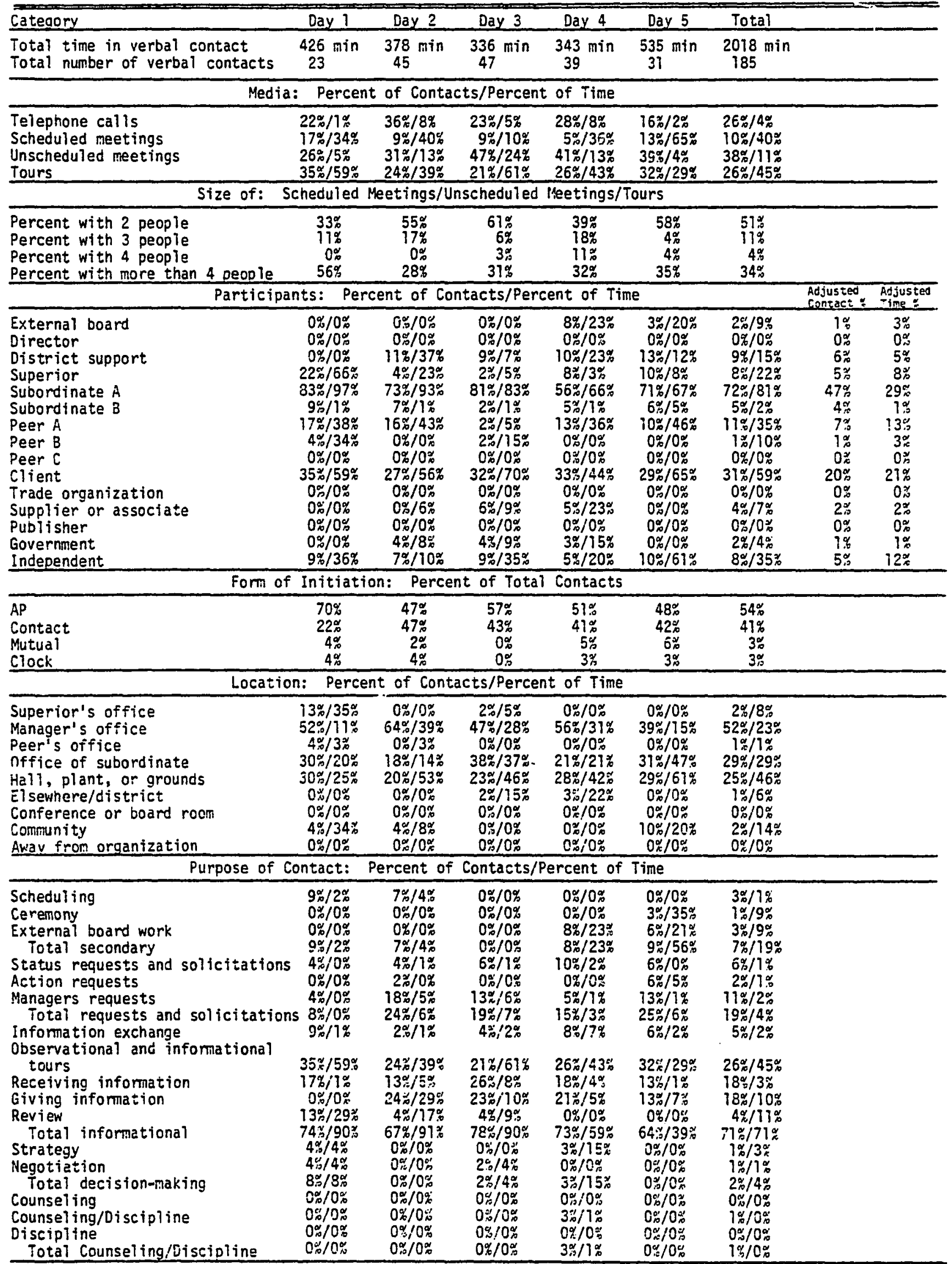


APPENCIX $F(3)$

CONTACT RECORD

ASSISTANT PRINICIPAL

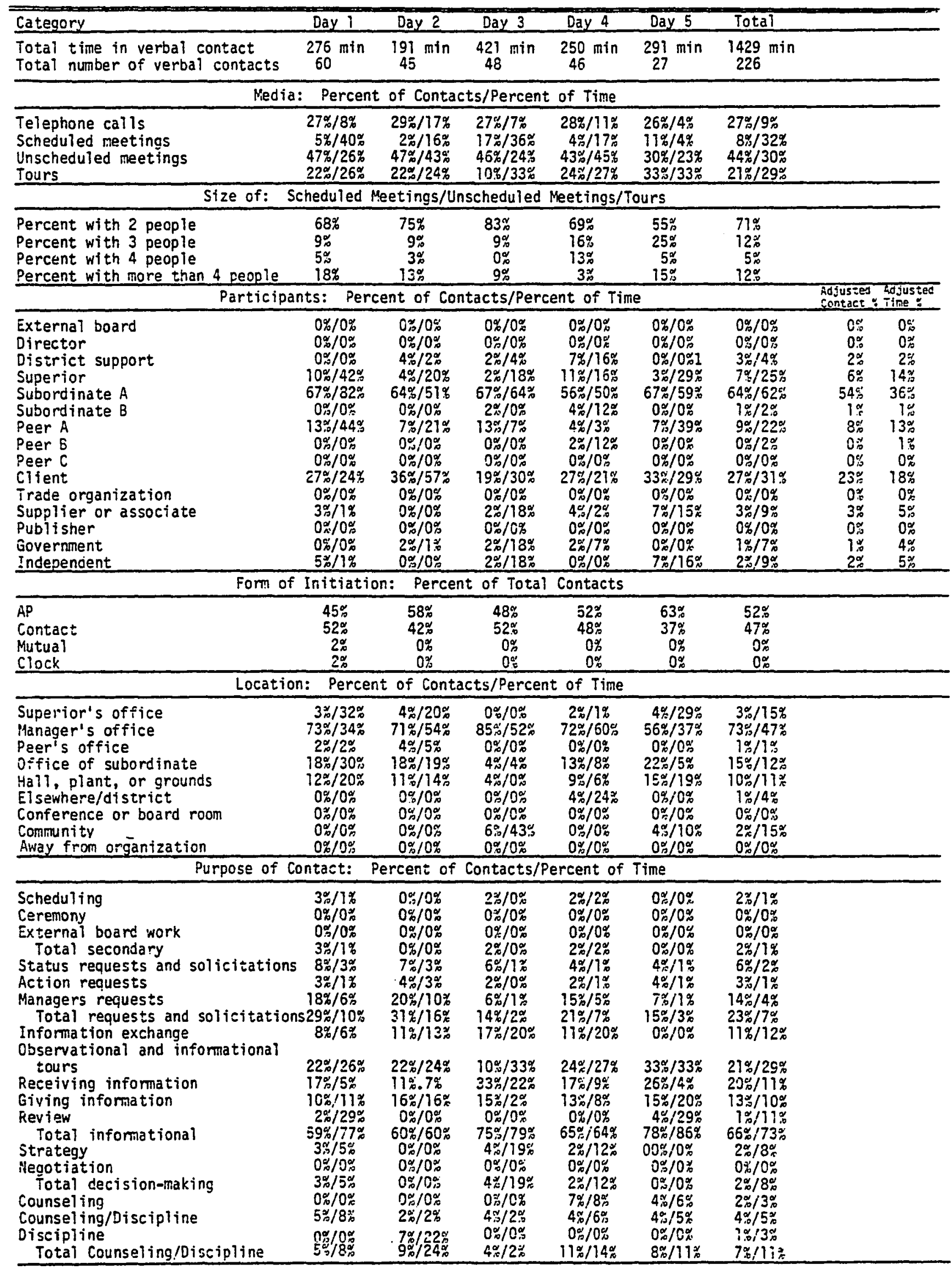


APPENDIX $F(4)$

CONTAET RECORD

186

ASSISTANT PRINCIPAL \#4

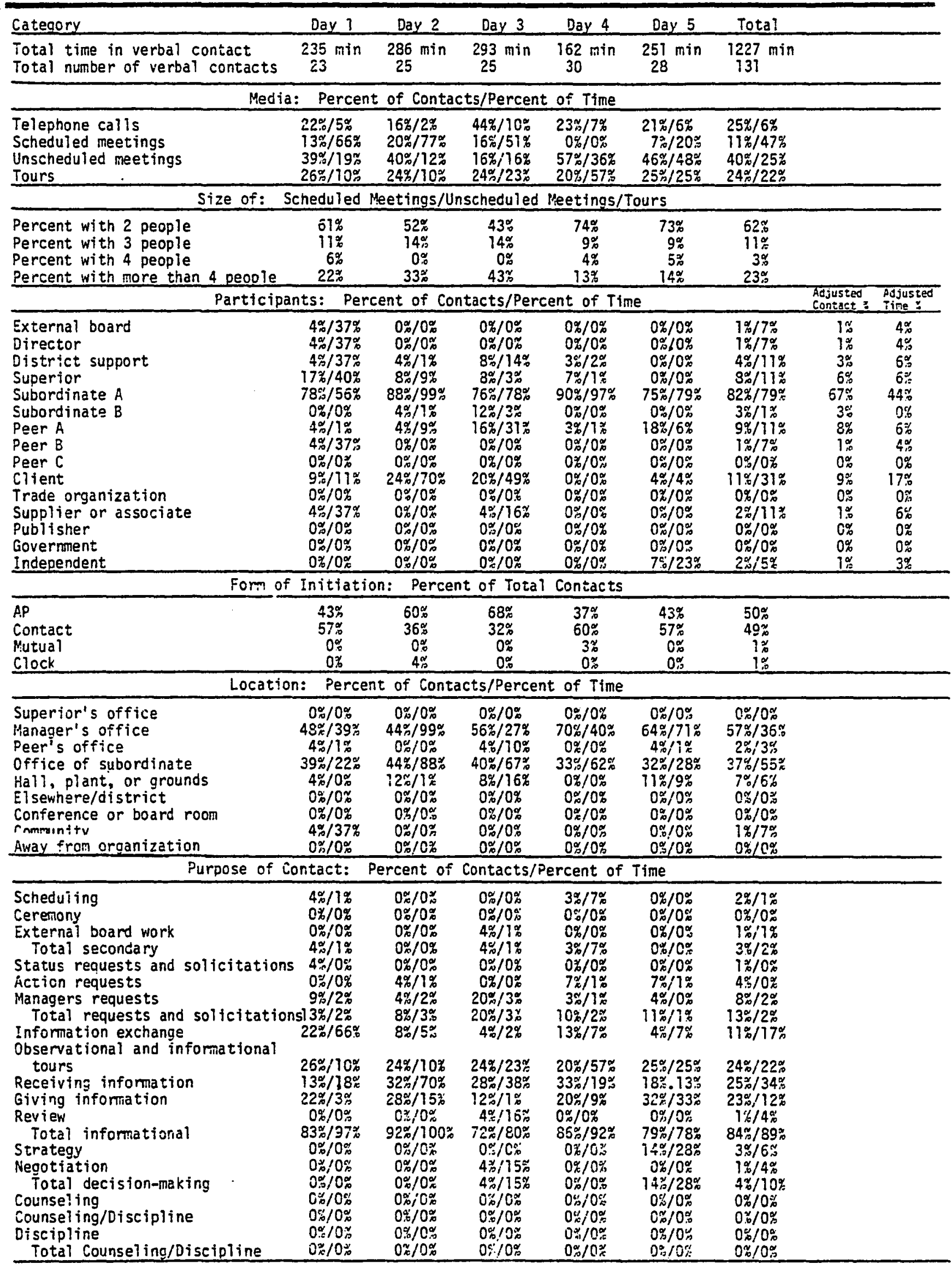


PPENIIX $F(5)$

CONTACT RECORD

187

ASSISTANT PRINCIPAL $\frac{4}{\pi}$

\begin{tabular}{|c|c|c|c|c|c|c|c|c|}
\hline Category & Day 1 & Day 2 & Day 3 & Day 4 & Day 5 & Total & & \\
\hline $\begin{array}{l}\text { Total time in verbal contact } \\
\text { Total number of verbal contacts }\end{array}$ & $\begin{aligned} 358 \\
46\end{aligned}$ & $\begin{array}{c}343 \min \\
49\end{array}$ & $\begin{array}{l}378 \text { min } \\
58\end{array}$ & 347 min & $\frac{249}{35} \min$ & $\begin{array}{r}1675 \min \\
221\end{array}$ & & \\
\hline \multicolumn{9}{|c|}{ Media: } \\
\hline $\begin{array}{l}\text { Telephone calis } \\
\text { Scheduled meotings } \\
\text { Unscheduled meetings } \\
\text { Tours }\end{array}$ & $\begin{array}{r}20 \% / 4 \% \\
0 \% / 0 \% \\
46 \% / 48 \% \\
35 \% / 48 \% \\
\end{array}$ & $\begin{array}{r}10 \% / 5 \% \\
0 \% / 0 \% \\
57 \% / 39 \% \\
39 \% / 57 \% \\
\end{array}$ & $\begin{array}{r}10 \% / 3 \% \\
5 \% / 17 \% \\
57 \% / 49 \% \\
28 \% / 31 \% \\
\end{array}$ & $\begin{array}{l}18 \% / 3 \% \\
9 \% / 50 \% \\
36 \% / 18 \% \\
36 \% / 30 \%\end{array}$ & $\begin{array}{l}6 \% / 2 \% \\
3 \% / 3 \% \\
51 \% / 43 \% \\
40 \% / 51 \%\end{array}$ & $\begin{array}{l}13 \% / 3 \% \\
3 \% / 15 \% \\
49 \% / 40 \% \\
35 \% / 43 \%\end{array}$ & & \\
\hline \multicolumn{9}{|c|}{ Size of: Scheduled Meetings/Unscheduied Pleetings/Tours } \\
\hline $\begin{array}{l}\text { Percent with } 2 \text { people } \\
\text { Percent with } 3 \text { people } \\
\text { Percent with } 4 \text { people } \\
\text { Percent with more than } 4 \text { people }\end{array}$ & $\begin{array}{r}49 \% \\
27 \% \\
3 \% \\
22 \% \\
\end{array}$ & $\begin{array}{r}45 \% \\
25 \% \\
7 \% \\
73 \% \\
\end{array}$ & $\begin{array}{r}60 \% \\
19 \% \\
4 \% \\
17 \% \\
\end{array}$ & $\begin{array}{l}33 \% \\
30 \% \\
15 \% \\
22 \% \\
\end{array}$ & $\begin{array}{l}58 \% \\
18 \% \\
12 \% \\
12 \% \\
\end{array}$ & $\begin{array}{r}50 \% \\
23 \% \\
7 \% \\
19 \% \\
\end{array}$ & \multirow{2}{*}{\multicolumn{2}{|c|}{$\begin{array}{l}\text { Adjustec Adjuste } \\
\text { Contast itme : }\end{array}$}} \\
\hline \multicolumn{7}{|c|}{ Participants: Percent of Contacts/Percent of Time } & & \\
\hline \multicolumn{2}{|c|}{$\begin{array}{lc}\text { External board } & 0 \% / 0 \% \\
\text { Director } & 0 \% / 0 \% \\
\text { District support } & 4 \% / 8 \% \\
\text { Superior } & 4 \% / 7 \% \\
\text { Subordinate A } & 72 \% / 80 \% \\
\text { Subordinate B } & 0 \% / 0 \% \\
\text { Peer A } & 2 \% / 17 \% \\
\text { Peer B } & 0 \% / 0 \% \\
\text { Peer C } & 0 \% / 0 \% \\
\text { Client } & 50 \% / 67 \% \\
\text { irade organization } & 0 \% / 0 \% \\
\text { Supplier or associate } & 0 \% / 0 \% \\
\text { Publisher } & 0 \% / 0 \% \\
\text { Government } & 0 \% / 0 \% \\
\text { Independent } & 2 \% / 0 \% \\
\end{array}$} & $\begin{array}{l}0 \% / 0 \% \\
0 \% / 0 \% \\
6 \% / 23 \% \\
4 \% / 10 \% \\
84 \% / 92 \% \\
6 \% / 8 \% \\
4 \% / 20 \% \\
0 \% / 0 \% \\
0 \% / 0 \% \\
45 \% / 71 \% \\
0 \% / 0 \% \\
0 \% / 0 \% \\
0 \% / 0 \% \\
0 \% / 0 \% \\
0 \% / 0 \% \\
\end{array}$ & $\begin{array}{l}0 \% / 0 \% \\
0 \% / 0 \% \\
3 \% / 2 \% \\
7 \% / 29 \% \\
69 \% / 82 \% \\
0 \% / 0 \% \\
7 \% / 20 \% \\
0 \% / 0 \% \\
0 \% / 0 \% \\
48 \% / 50 \% \\
0 \% / 0 \% \\
2 \% / 2 \% \\
0 \% / 0 \% \\
0 \% / 0 \% \\
0 \% / 3 \% \\
\end{array}$ & $\begin{array}{l}0 \% / 0 \% \\
0 \% / 0 \% \\
12 \% / 47 \% \\
6 \% / 13 \% \\
61 \% / 43 \% \\
6 \% / 47 \% \\
3 \% / 7 \% \\
3 \% / 47 \% \\
0 \% / 0 \% \\
58 \% / 50 \% \\
0 \% / 0 \% \\
0 \% / 0 \% \\
0 \% / 0 \% \\
0 \% / 0 \% \\
0 \% 10 \% \\
\end{array}$ & $\begin{array}{c}0 \% / 0 \% \\
0 \% / 10 \% \\
3 \% / 5 \% \\
3 \% / 8 \% \\
80 \% / 85 \% \\
0 \% / 0 \% \\
3 \% 16 \% \\
0 \% / 0 \% \\
0 \% / 0 \% \\
37 \% / 44 \% \\
0 \% / 0 \% \\
0 \% 10 \% \\
0 \% / 0 \% \\
0 \% / 0 \% \\
3 \% / 11 \% \\
\end{array}$ & $\begin{array}{c}0 \% / 0 \% \\
0 \% / 0 \% \\
5 \% / 17 \% \\
5 \% / 14 \% \\
73 \% / 76 \% \\
2 \% / 10 \% \\
4 \% / 13 \% \\
0 \% / 9 \% \\
0 \% / 0 \% \\
48 \% / 57 \% \\
0 \% 10 \% \\
0 \% / 0 \% \\
0 \% / 10 \% \\
0 \% / 10 \% \\
0 \% \\
1 \% / 2 \% \\
\%\end{array}$ & $\begin{aligned} 0 \% \\
0 \% \\
4 \% \\
4 \% \\
5 \% \% \\
5 \% \\
2 \% \\
3 \% \\
0 \% \\
0 \% \\
0 \% \\
34 \% \\
0 \% \\
0 \% \\
0 \% \\
0 \% \\
0 \% \\
1 \% \\
\%\end{aligned}$ & $\begin{array}{r}0 \% \\
0 \% \\
9 \% \\
7 \% \\
78 \% \\
5 \% \\
5 \% \\
7 \% \\
4 \% \\
0 \% \\
29 \% \\
0 \% \\
0 \% \\
0 \% \\
0 \% \\
0 \% \\
1 \% \\
\end{array}$ \\
\hline \multicolumn{9}{|c|}{ Form of Initiation: } \\
\hline $\begin{array}{l}\text { AP } \\
\text { Contact } \\
\text { Mutual } \\
\text { Clock } \\
\end{array}$ & $\begin{array}{r}70 \% \\
26 \% \\
4 \% \\
0 \% \\
\end{array}$ & $\begin{array}{r}49 \% \\
45 \% \\
6 \% \\
0 \% \\
\end{array}$ & $\begin{array}{r}38 \% \\
57 \% \\
3 \% \\
2 \% \\
\end{array}$ & $\begin{array}{r}61 \% \\
36 \% \\
0 \% \\
3 \% \\
\end{array}$ & $\begin{array}{r}46 \% \\
49 \% \\
6 \% \\
0 \% \\
\end{array}$ & $\begin{array}{r}52 \% \\
43 \% \\
4 \% \\
1 \% \\
\% \\
\end{array}$ & & \\
\hline \multicolumn{9}{|c|}{ Location: Percent of Contacts!Percent of Time } \\
\hline $\begin{array}{l}\text { Superior's office } \\
\text { Manager's office } \\
\text { Peer's office } \\
\text { office of subordinate } \\
\text { Hali, plant, or grounds } \\
\text { Elsewhere/district } \\
\text { Conference or board roon } \\
\text { Community } \\
\text { Away from organization }\end{array}$ & $\begin{array}{c}0 \% / 0 \% \\
72 \% / 55 \% \\
0 \% / 10 \% \\
24 \% / 38 \% \\
13 \% / 35 \% \\
0 \% / 0 \% \\
0 \% / 0 \% \\
0 \% / 0 \% \\
0 \% / 0 \% \\
\end{array}$ & $\begin{array}{l}2 \% / 4 \% \\
55 \% / 38 \% \\
0 \% / 0 \% \\
27 \% / 20 \% \\
20 \% / 49 \% \\
0 \% / 0 \% \\
0 \% / 0 \% \\
0 \% / 0 \% \\
0 \% / 0 \% \\
\end{array}$ & $\begin{array}{r}2 \% / 3 \% \\
74 \% / 57 \% \\
0 \% / 10 \% \\
22 \% / 12 \% \\
12 \% / 21 \% \\
0 \% / 0 \% \\
2 \% / 14 \% \\
0 \% / 0 \% \\
0 \% / 0 \% \\
\end{array}$ & $\begin{array}{l}0 \% / 0 \% \\
58 \% / 28 \% \\
0 \% / 0 \% \\
24 \% / 10 \% \\
18 \% / 26 \% \\
3 \% / 41 \% \\
3 \% / 41 \% \\
0 \% / 0 \% \\
0 \% 10 \% \\
\end{array}$ & $\begin{array}{l}0 \% / 0 \% \\
79 \% / 55 \% \\
0 \% / 0 \% \\
9 \% / 6 \% \\
20 \% / 39 \% \\
0 \% / 0 \% \\
0 \% / 0 \% \\
0 \% / 0 \% \\
0 \% / 0 \% \\
\end{array}$ & $\begin{array}{l}1 \% / 2 \% \\
57 \% / 46 \% \\
0 \% / 10 \% \\
22 \% / 18 \% \\
16 \% / 33 \% \\
0 \% / 9 \% \\
1 \% / 12 \% \\
0 \% / 10 \% \\
0 \% / 10 \% \\
\end{array}$ & & \\
\hline \multicolumn{9}{|c|}{ Purpose of Contact: } \\
\hline $\begin{array}{l}\text { Scheduling } \\
\text { Ceremony } \\
\text { External board work } \\
\text { Total secondary } \\
\text { Status requests and solicitations } \\
\text { Action requests } \\
\text { Managers requests } \\
\text { Total requests and solicitation } \\
\text { Information exchange } \\
\text { Observational and informationai }\end{array}$ & $\begin{array}{r}0 \% / 0 \% \\
0 \% / 0 \% \\
0 \% / 10 \% \\
0 \% / 0 \% \\
0 \% / 10 \% \\
0 \% / 10 \% \\
0 \% \\
4 \% / 1 \% \\
\text { ns } 4 \% / 1 \% \\
2 \% / 6 \%\end{array}$ & $\begin{array}{r}4 \% / 1 \% \\
0 \% / 0 \% \\
0 \% / 0 \% \\
4 \% / 1 \% \\
0 \% / 0 \% \\
12 \% / 3 \% \\
0 \% / 1 \% \\
12 \% / 4 \% \\
8 \% / 2 \%\end{array}$ & $\begin{array}{c}2 \% / 1 \% \\
0 \% / 0 \% \\
0 \% / 0 \% \\
2 \% / 1 \% \\
2 \% / 0 \% \\
10 \% / 4 \% \\
0 \% / 1 \% \% \\
12 \% / 4 \% \\
10 \% / 21 \%\end{array}$ & $\begin{array}{l}0 \% / 0 \% \\
0 \% / 0 \% \\
0 \% / 0 \% \\
0 \% / 0 \% \\
0 \% / 0 \% \\
0 \% / 0 \% \\
0 \% / 0 \% \\
0 \% / 0 \% \\
6 \% / 3 \%\end{array}$ & $\begin{array}{c}0 \% / 0 \% \\
0 \% / 0 \% \\
0 \% / 0 \% \\
0 \% / 0 \% \\
0 \% / 0 \% \\
3 \% / 0 \% \\
0 \% / 0 \% \\
3 \% / 0 \% \\
3 \% \% / 23 \% \\
74 \% \\
4 \%\end{array}$ & $\begin{array}{l}1 \% / 0 \% \\
0 \% / 0 \% \\
0 \% / 0 \% \\
1 \% / 0 \% \\
0 \% / 0 \% \\
6 \% / 7 \% \\
1 \% / 0 \% \\
7 \% / 1 \% \% \\
7 \% \% \\
8 \%, 12 \%\end{array}$ & & \\
\hline $\begin{array}{l}\text { tours } \\
\text { Receiving information } \\
\text { Giving infomation } \\
\text { Review } \\
\text { Total infomational } \\
\text { Strategy } \\
\text { Negotiation } \\
\text { Totai decision-making } \\
\text { Counseling } \\
\text { Counseling/Discipline } \\
\text { Discipline } \\
\text { Total Counseling/Discio?ine }\end{array}$ & $\begin{array}{l}35 \% / 48 \% \\
26 \% / 6 \% \\
11 \% / 4 \% \\
2 \% / 6 \% \\
76 \% / 70 \% \\
0 \% \% \\
0 \% \% \\
2 \% / 6 \% \\
2 \% / 6 \% \\
9 \% / 18 \% \\
7 \% / 2 \% \\
4 \% / 2 \% \\
20 \% / 28 \% \\
\end{array}$ & $\begin{array}{l}39 \% / 57 \% \\
12 \% / 7 \% \\
16 \% / 8 \% \\
2 \% / 1 \% \\
77 \% / 81 \% \\
0 \% / 0 \% \\
0 \% / 0 \% \\
0 \%, 10 \% \\
0 \%, 10 \% \\
2 \% / 3 \% \\
6 \% / 12 \% \\
0 \%, 10 \% \\
3 \% / 15 \% \\
\end{array}$ & $\begin{array}{l}28 \% / 31 \% \\
12 \% / 3 \% \\
19 \% / 6 \% \\
2 \%, 14 \% \\
71 \% / 75 \% \\
2 \% / 7 \% \\
0 \% / 0 \% \\
2 \% / 7 \% \\
0 \% / 0 \% \\
17 \% / 15 \% \\
0 \% / 10 \% \\
17 \% / 15 \% \\
\end{array}$ & $\begin{array}{l}36 \% / 30 \% \\
24 \% / 5 \% \\
21 \% / 11 \% \% \\
3 \% / 47 \% \\
90 \% / 90 \% \\
0 \% / 0 \% \\
0 \% / 0 \% \\
0 \% / 0 \% \\
0 \% / 10 \% \\
6 \% / 6 \% \\
3 \% / 3 \% / \\
9 \% / 9 \% \\
\%\end{array}$ & $\begin{array}{r}40 \% / 51 \% \\
20 \% / 10 \% \\
11 \% \\
0 \% / 3 \% \\
0 \% \% \\
91 \% / 97 \% \\
0 \% / 0 \% \\
0 \% / 0 \% \\
0 \% / 0 \% \\
0 \% / 0 \% \\
9 \% / 8 \% \\
3 \% / 3 \% \\
12 \% / 11 \% \\
\end{array}$ & $\begin{array}{l}35 \% / 43 \% \\
19 \% / 6 \% \\
16 \% / 8 \% \\
2 \% / 13 \% \\
50 \% / 8 \% \% \\
0 \% / 1 \% \\
0 \% / 1 \% \\
0 \% / 2 \% \\
2 \% / 5 \% \\
10 \% / 10 \% \\
2 \% / 1 \% \\
14 \% / 16 \% \\
4 \%\end{array}$ & & \\
\hline
\end{tabular}

